Portland State University

PDXScholar

Fall 10-23-2019

\title{
The Many Wives of General August V. Kautz: Colonization in the Pacific Northwest, 1853-1895
}

Nicole Ann Kindle

Portland State University

Follow this and additional works at: https://pdxscholar.library.pdx.edu/open_access_etds

Part of the Women's History Commons

Let us know how access to this document benefits you.

\section{Recommended Citation}

Kindle, Nicole Ann, "The Many Wives of General August V. Kautz: Colonization in the Pacific Northwest, 1853-1895" (2019). Dissertations and Theses. Paper 5358.

https://doi.org/10.15760/etd.7231

This Thesis is brought to you for free and open access. It has been accepted for inclusion in Dissertations and Theses by an authorized administrator of PDXScholar. Please contact us if we can make this document more accessible: pdxscholar@pdx.edu. 
The Many Wives of General August V. Kautz:

Colonization in the Pacific Northwest, 1853-1895

by

Nicole Ann Kindle

A thesis submitted in partial fulfillment of the requirements for the degree of

\author{
Master of Arts \\ in \\ History
}

\author{
Thesis Committee: \\ Katrine Barber, Chair \\ Tim Garrison \\ Marc Rodriguez
}

Portland State University

2019 
(C) 2019 Nicole Ann Kindle 


\begin{abstract}
This thesis is about the colonization of the West, with an emphasis on the Pacific Northwest from 1853 to 1895 . It analyzes the historical processes occurring as America expanded westward through the lens of the Kautz family. August Kautz and his wives tell the story of colonization through unique and vastly different ways. This thesis argues that a microanalysis of the Kautz family history tells a greater story of colonization, one rife with complicated layers influenced by race, class, and societal expectations that shaped individual roles within colonization.
\end{abstract}

August Kautz was a lieutenant when he first arrived in the Pacific Northwest in 1853; there, he met and married his first wife, a Nisqually woman named Kitty, and together they had two sons. Kautz was an advocate for the release of Chief Leschi, a prominent Nisqually leader during the Puget Sound Indian Wars, connected to August through a familial relation to Kitty. August, as a member of the United States military, was an agent of colonization. Kitty responded and navigated through her changing world. August eventually left his first family in the Pacific Northwest to fight for the Union during the Civil War, and later married Fannie Markbreit, a white middle-class woman from Ohio, in 1872. His relationship with Fannie and their subsequent children was drastically different. Together with Fannie, they actively participated in the colonization of the West through military movements, and Fannie participated in theater groups 
as an officer's wife and assisted the spread of eastern cultural values while stationed at western posts.

This thesis chronologically follows the Kautz family. Chapter one focuses on August's relationship with Kitty and their two sons. The chapter also examines the greater events that occurred in the Pacific Northwest while he and Kitty created their family, and how his actions aided the colonization of the American West. Chapter two follows August after he leaves Kitty and their sons. The chapter centers on his wife Fannie, their children, and the larger historical events as they moved to various forts throughout the West with the United States military. Chapter three begins with August's death and follows the fate of both of his families dealing with the aftermath of the event. 


\section{Acknowledgments}

Writing this thesis has been a constant challenge, I wanted to give up more times than I can count. The fact that I did not was more a testament to my incredible support system rather than personal willpower. The endless encouragement and support I received during this process contributed to my success more than anyone could possibly know.

Weekly writing sessions with Tanya Monthey held me accountable for setting aside time to write while we both worked full time. Without Tanya's time, encouragement, accountability, and support I might not have ever finished. Nayomi Kanz graciously edited and provided encouragement and feedback throughout this process, without her expertise there would be a lot more mistakes. Megan Ockerman and Allison Gammon's feedback on content and structure helped transform this thesis into its final draft. I owe you all a debt of gratitude for your help.

This thesis would not be what it is without the support, influence, critiques, and feedback of Professor Katy Barber. I could not have asked for a better advisor. Thank you for challenging me, encouraging me and above all, thank you for your guidance and patience.

I also owe thanks to Donna Sinclair, I worked as Donna's Graduate Research Assistant on a Historical Resources Study for the National Park Service at Fort Vancouver. This project introduced me to my subject, and Donna encouraged me to pursue it. 
The support of the history department has been instrumental in my success. Professors Tim Garrison and Marc Rodriguez served on my committee and their final comments and suggestions polished the final draft of this thesis. I was also lucky enough to receive funds from the Lauren Banasky Grant, which allowed me to travel to Washington D.C. to do research at the Library of Congress. The research I conducted during my trip was instrumental in completing my thesis.

To my dear friends Mackenzie Chapman, Miranda Fickle, Sarah Hogan, Amy Keough, Katy Kline, and Ayla Williams, your constant encouragement motivated me more than any words can express. Thank you for listening to me complain for all these years. To Andrew Crookston, for making sure I ate while I zoned out for hours at a time researching and writing, and for not judging me when I funneled scrambled eggs into my mouth with my bare hands.

Thank you does not seem a strong enough word to capture my sentiments, but it is all I have. 


\section{Table of Contents}

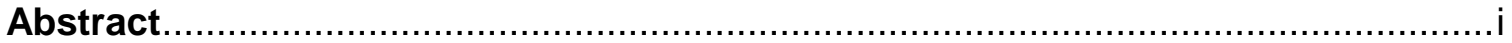

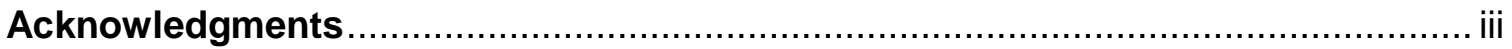

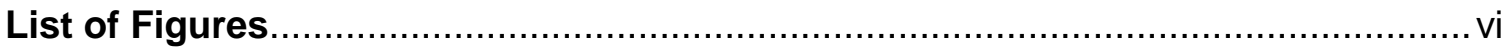

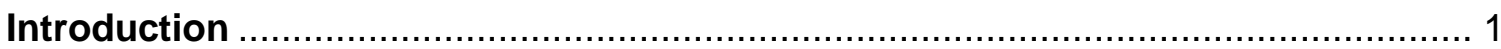

Chapter One

"After the Manner of My Mother's People": Washington Territory, 1853-1861 ...............20

Chapter Two

“My Poor Silly Wife”: Fannie Markbreit Kautz, 1872-1892........................................69

Chapter Three

"Nothing Worthy of Note Transpired": The Kautz Family Legacy .............................112

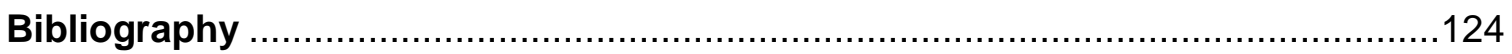




\section{List of Figures}

Figure 1. Timeline: August and Kitty Kautz \& the Pacific Northwest, 1846 - 1868 (51)

Figure 2. Timeline: August and Fannie Kautz \& U.S. Western Posts, 1861 - 1892 (99)

Figure 3. Kautz Family: Births, Marriages, and Deaths, 1828 - 1970 (122) 


\section{Introduction}

\section{Levanna, Ohio - 1844}

High on a bluff, a young boy climbs up into a tree. He begins to pound a nail intently through a block of wood, securing it to the trunk. The sound of the hammer rings out across the river. Pausing, the boy relaxes comfortably on a branch, looking out over the Ohio River. He stares at the rushing water, pondering where his life will take him. ${ }^{1}$

Historical reflection on military men is often done by way of the battles they fought. The story of General August V. Kautz, however, does not belong on the battlefield. His mediocre successes and blunders followed his reputation through his retirement, and he did very little to distinguish himself in combat. Kautz fought in the Civil War but did not reach the same notoriety as Generals Ulysses S. Grant, Philip Sheridan, and William T. Sherman--men he called, at times, close friends, classmates, and colleagues. The majority of my research focuses on his life outside of his military career. Kautz's story is that of a young American soldier stationed in the isolation of the Pacific Northwest in what is now Oregon and Washington. It takes him east to fight for the Union in the Civil War, and then west again. His story is one rife with layers; each layer accentuated more by the relationships he formed throughout his life than by battles and military glory.

Frederick Jackson Turner's 1893 presentation "The Significance of the Frontier in American History" closed the frontier in 1890 and inspired a

\footnotetext{
${ }^{1}$ Lawrence G. Kautz, August Valentine Kautz, USA: Biography of a Civil War General (Jefferson, N.C.: McFarland \&, Publishers, 2008), 8.
} 
foundation for the history of the American West. Turner's thesis emphasized the movement of the American people to a new and empty land, but he minimized the roles of women and people of color. Initially following Turner's exclusionary path, Ray Allen Billington's Westward Expansion: A History of the American Frontier, attempts to acknowledge and incorporate an expanded and inclusive history of the West in the expanded version with Martin Ridge published in 1982. The history perpetuated by Turner and Billington is one forcefully constructed out of a violent, resistant environment and depicted hard-working men taming the land. While it excludes key actors, it emphasized the gaps for new study.

The omission of gender and racial analysis of the West led to the rise of New Western history, which expanded historiography by incorporating the diversity of those who shaped the West. While the mythology of the West perpetuated a white, Euro-American, male-dominated version of history, the incorporation of diverse stories reimagined the landscape. Patricia Limerick, in The Legacy of Conquest: The Unbroken Past of the American West, first published in 1987, emphasizes the necessity of incorporating the stories of women across class and race lines. Margaret $D$. Jacobs argues that the misleading image of western women conjures up the image of the hardened pioneer wife working alongside her husband, who set west in search of riches and freedom. She was a strong moral figure, influencing the formation of civilized society, she identifies the issue as the "sun bonneted Madonna of the prairie," and emphasizes the need to expand and decolonize the story of women in the 
West. $^{2}$ The white pioneer female was not alone in the shaping of her homelands. Limerick argues that the women of the west were far from innocent victims and passive participants; they were active in directing their lives. Women adapted to and transformed their physical and social landscapes wherever they went. Susan Armitage's The Women's West (1987), and Lillian Schlissel and Vicki Ruiz's Western Women: Their Lands, Their Lives (1988) also contributed greatly to the field, diversifying the history of the West and the role of women by analyzing their social, economic and political contributions. Historian Anne Hyde's Empires, Nations, and Families: A History of the North American West, 1800-1860, published in 2011 refocused the study of the American West through the scope of family alongside state politics that developed over time to understand the transformation of the American West and American families.

The study of officer's wives has been limited to the diaries kept by a few women. An Army Wife on the Frontier: The Memoirs of Alice Blackwood Baldwin, 1867-1877 and The Colonel's Lady on the Western Frontier: The Correspondence of Alice Kirk Grierson, as well as Michele Nacy's work Members of the Regiment: Army Officers' Wives on the Western Frontier, 1865-1890 published in 2000. Nacy examines the unique role of officers' wives in the West. They did not settle on homesteads and build communities, nor were they officially a part of the military, yet they were still agents of colonization. Scholarship on women's role in theater participation has focused on the professional careers of

\footnotetext{
2 Margaret D. Jacobs, "Getting Out of a Rut: Decolonizing Western Women's History," Pacific Historical Review 79, no. 4 (2010), 586.
} 
women actors and the public perception of women as performers and spectators. Faye Dudden's 1994 work, Women in the American Theatre: Actresses and Audiences, 1790-1870, emphasize the public role in female participation, but does not analyze the amateur theater groups within the United States military and the officer's wives who participated at Western forts. Despite the rise of New Western History, much of the women's history in the field focuses on white women's stories.

As New Western history emerged, Indigenous women's history was notably lacking within the field of women's history. A majority of current scholarship focuses on Indian women who intermarried. Historian Sylvia Van Kirk contributed to the field through her research on Indigenous women's roles and intermarriage in fur trade society in Canada with her work "Many Tender Ties": Women in Fur-Trade Society in Western Canada, 1670-1870, published in 1980. Van Kirk acknowledges that Indian women did not leave a record of their lives and that the study of intermarriage in fur trade society originates from the fur traders' themselves. ${ }^{3}$ David Peterson Del Mar also highlights this common problem in determining Indian women's agency in intermarriage in his 1995

\footnotetext{
${ }^{3}$ Sylvia Van Kirk, "Many Tender Ties": Women in Fur-Trade Society in Western Canada, 16701870, (Winnipeg, Man: Watson \& Dwyer, 1980), 75. Many Tender Ties focuses on Indigenous women's contributions to the Canadian West Fur Trade, and the agency they used to navigate their own changing world. Robin Brownlie and Valerie J. Korinek's Finding a Way to the Heart: Feminist Writings on Aboriginal and Women's History in Canada, is a compilation of scholarly essays that expand on Van Kirk's work of Indigenous Women's history. Extending beyond the Canadian West into America and Australia on the foundations of her transformation of the historical understanding of the North American Fur Trade.
} 
article "Intermarriage and Agency: A Chinookan Case Study."4 Peggy Pascoe, writing in 2009, What Comes Naturally: Miscegenation Law and the Making of Race in America, analyzes interracial relationships. Pascoe's analysis extends beyond southern states, and into the American West. Pascoe highlights the expansive racial motivations and consequences of miscegenation laws throughout the United States. The laws prohibiting interracial marriage, Pascoe argues, also affected segregation, and racial restrictions in regard to suffrage, citizenship, and inheritance. Katrina Jagodinsky's Legal Codes and Talking Trees: Indigenous Women's Sovereignty in the Sonoran and Puget Sound Borderlands, 1854-1946, presents six case studies analyzing the ways in which territorial courts asserted their control over Indigenous women's inheritance and maternal rights, and how these women fought back. Jagodinsky's work greatly contributed to my analysis of Kitty and how the court system shaped her life as an Indigenous woman and mother in the Pacific Northwest. Brad Asher's 1995 work Beyond the Reservation: Indians, Settlers, and the Law in Washington Territory, 1853-1889 examines territorial court records for Indian presence in the lower courts of Washington Territory, specifically involving cases of land rights and inheritance. Walter Echohawk further expanded on the injustice faced by Indigenous people in the American court system in 2010 with his work, In the Courts of the Conqueror: The 10 Worst Indian Law Cases Ever Decided. Echohawk examines cases involving Indigenous people, and the ways in which

\footnotetext{
${ }^{4}$ David Peterson Del Mar, "Intermarriage and Agency: A Chinookan Case Study," Ethnohistory 42, no. 1 (1995), 2.
} 
the United States continues to use the legal system to deprive Native Americans of land rights and to justify federal policies that threaten tribal sovereignty. Kim Anderson's A Recognition of Being: Reconstructing Native Womanhood published in 2000 , explores the position of Native women in traditional cultures prior to Euro-American presence, and after. She notes that Native women were forced into the model of womanhood placed upon them by the incoming colonizing societies. Anderson offers tools for Indigenous women to reclaim their Native identity, and how to use those tools to reshape their community and traditions.

The initial goal of my thesis was to make August's wives the center of the story; in some ways, I have failed. I knew my sources were limited, and relying on his journals meant the story followed the trajectory of August's life, one intertwined with his relationships, both with his wives and his children. It is not his story, it is their story. Building on the work of historians Susan Armitage and Lillian Schlissel, I examine the diverse ways in which Kitty and Fannie contributed to the settling of the American West. I focus on Kitty's agency in her relationship with August, how she navigated her changing world and the effect on her children. The scholarship on officer's wives primarily focuses on their roles and struggles while following their husbands on the rugged and dangerous frontier; Fannie's experiences were different as she navigated a more developed land. By comparing these women's lives and relationships with the same man, I offer a unique insight into the unfolding of colonization in the West. 
August Valentine Kautz was born in Ispringen, Germany on January 5, 1828. ${ }^{5}$ His parents, George and Dorothy, emigrated from Germany with George's mother and siblings in August of 1828, before August was a year old. ${ }^{6}$ The family arrived in Baltimore, Maryland and made their way to Brown County, Ohio to a plot of land purchased by Christoph Kautz, August's grandfather, who passed away before he could realize his dream of taking the family to the United States. ${ }^{7}$

After several career undertakings, George Kautz eventually started a career in cabinet making to support his family, the rest of George's extended family settled around various parts of Ohio. Brown County, Ohio was home to many German immigrants. Among the more famous residents were prominent military leaders, including famed Civil War General Ulysses S. Grant, the 18th President of the United States and a fellow soldier and friend of Kautz's. Growing up in Ohio, August, and his siblings--seven in total, only one a girl--were at the whim of their father's ever-changing interests. The family settled in the town of Levanna, where August built a treehouse that overlooked the Ohio River. In addition to his cabinet making, George Kautz decided to become a vintner, which would help support his family while August came of age. ${ }^{8}$

As Kautz was leaving boyhood, greater political events began to shape his life. Texas officially became a state in 1845 with the signature of President Polk.

\footnotetext{
5 Unpublished Draft of Autobiography, Box 8, August V. Kautz Papers, Manuscript Division, Library of Congress. Washington, D.C.

${ }^{6}$ Kautz, Biography of a Civil War General, 3. Augusts' father, Johann Georg, went by George upon arrival in the United States. His mother's name changed from Dorothea to Dorothy.

${ }^{7}$ Kautz, Biography of a Civil War General, 3.

${ }^{8}$ Ibid., 4-8.
} 
In 1846, Mexican troops were sent to the border of Texas. Consequently, United States troops were sent to Texas under the command of General Zachary Taylor, along with orders to muster up more troops at the request of President Polk. ${ }^{9}$ The President's request signaled the start of the Mexican-American War, and the Ohio Volunteers were formed. Among their ranks was young August Kautz. The First Volunteer Brigade of Ohio mustered into service on June 27, 1846. ${ }^{10}$ Upon his return from a year of battles and hardship, August and the Brown County soldiers were welcomed back by an enthusiastically cheering crowd. Kautz reflected in his unpublished autobiography that he "never felt so proud or so repaid for a year's hardship" as at that moment. ${ }^{11}$ Enamored with the glory of military life, he wanted to further his military career. He received a nomination for West Point from Representative Jonathan D. Morris and was accepted on March $20,1848--a n$ event that would shape the outcome of his life and relationships. ${ }^{12}$ Among his classmates and fellow Ohioans at West Point were the future generals memorialized by their deeds during the Civil War. Five Ohioans in West Point's graduating class of 1852 would go on to rise to the rank of Major General or Brevet Major General during the Civil War while fighting for the Union Army: David Stanley, George Crook, Charles Woods, Alexander McCook, and August Kautz. Philip Sheridan would have been placed in this list had he not been held

\footnotetext{
${ }^{9}$ lbid., 9.

${ }^{10}$ August Kautz Letter to President Chester Arthur, March 26, 1883, Box 7, August V. Kautz Papers, Manuscript Division, Library of Congress, Washington, D.C.

${ }^{11}$ Kautz, Biography of a Civil War General, 15.

12 lbid., 15.
} 
behind at West Point one year for unknown disciplinary reasons. ${ }^{13}$ Sheridan would remain a constant in Kautz's life, both as a friend and a rival. Sheridan rose to Civil War fame after his appointment to Major General in the Army by President Lincoln. Major General Sheridan and his troops managed to block General Lee's final line of retreat at Appomattox, where Lee surrendered, guaranteeing Sheridan's place of esteem in the military and leading to his appointment as Head of the Department of Missouri in 1867. Sheridan, later known as the "Chief Indian Fighter of the Nation," had little sympathy for Indians and strongly supported the reservation system. He believed it was right to segregate Indians, but also felt the United States Government failed them by not delivering on their promises of necessary food and goods. ${ }^{14}$

Upon graduation from West Point in 1852, Brevet Second Lieutenant August Kautz, along with fellow classmates, received their assignments. Kautz joined the 4th U.S. Infantry Regiment, famous for its many high-achieving members, including Ulysses S. Grant. ${ }^{15}$ In 1852, Kautz received his official orders and began the journey to Fort Vancouver, located across the Columbia River from Portland, Oregon in what is present-day Vancouver, Washington. ${ }^{16}$

\footnotetext{
${ }^{13}$ lbid., 16.

14 Donna Sinclair, "Part I, 'Our Manifest Destiny Bids Fair for Fulfillment': An Historical Overview of Vancouver Barracks, 1846-1898, with Suggestions for Further Research," Center for Columbia River History, (2004), 110-11.

${ }^{15}$ August Kautz Letter to President Chester Arthur, Box 7, August V. Kautz Papers, Library of Congress, \& Kautz, Biography of a Civil War General, 17.

${ }^{16}$ August Kautz Letter to President Chester Arthur, Box 7, August V. Kautz Papers, Library of Congress \& Kautz, Biography of a Civil War General, 18. Fort Vancouver was originally called Columbia Barracks and is also referred to as Vancouver Barracks.
} 
As an officer in the United States Army, Kautz played a key role in the colonization of the West. While stationed in Washington Territory as a young officer, he met an Indian woman, Kitty, with whom he had two children. This relationship and the entirety of his family history tells the complicated and sometimes violent story of colonization. August's participation in colonization did not end with his relationship with Kitty. While he remained in intermittent contact with his eldest sons throughout the rest of his life, he eventually returned to Ohio and remarried. His second wife, Charlotte Tod, would tragically die; then he married again to Fannie Markbreit, with whom he had three more children. Fannie accompanied him back west, with the status of an officers' wife. His time spent in the west with Fannie at his side differed from his life with Kitty. Fannie enjoyed the benefits of being a white woman and an officers' wife at Western forts. While Kitty benefited from her relationship with August, the dynamics were drastically different--shaped by race, and class.

The story of the Kautz family is a microhistory. This thesis examines their family history to analyze the larger historical process of which August and his separate families were participants. This thesis offers a unique perspective on the role of settler colonialism by examining the diverse family history of the Kautzes. This story is unique in that August's choice of wives created two distinct family units that were multigenerational and racially diverse. Impacted by colonization and social change, these seemingly ordinary people were distinctly 
affected by the process of change. ${ }^{17}$ As the United States expanded westward throughout the nineteenth century and worked to disenfranchise native populations of their land, Kautz's role as an officer in the army promoted expansion and colonization. His relationships with these two women exemplify the participation August, and his family had in colonization. August's relationship and family with Fannie show a different story of colonization than with his first family with Kitty during his original assignment in the Pacific Northwest in the 1850s.

During his first assignment, Kautz helped to promote and expand westernized ideas of civilization through the military establishment in the Pacific Northwest. Land grabbing, removal, and violence were popular strategies for addressing native populations during this time. The West that operated on trade and personal relationships with Indigenous tribes moved towards a system of land acquisition, and the Indigenous population impeded American expansion. ${ }^{18}$ American expansion was fueled by Manifest Destiny, a phrase coined in 1845, which represents the distinctly American belief that God wanted Americans to have dominion over the land from the Atlantic to the Pacific. ${ }^{19}$ The following decades were dominated by nation building and settler colonialism. Margaret Jacobs points out that the term settler colonialism conjures up an unrealistic

\footnotetext{
17 Tamara K. Haraven, "The History of the Family and the Complexity of Social Change," The American Historical Review 96, no. 1 (1991), 95-124.

${ }^{18}$ Anne F. Hyde, Empires, Nations, and Families: A History of the North American West, 18001860, (Lincoln: University of Nebraska Press, 2011), 225-226.

${ }^{19}$ Kevin Hillstrom and Laurie Collier Hillstrom, American Indian Removal and the Trail to Wounded Knee, (Detroit, Ml: Omnigraphics, 2010), 35.
} 
image--one of peaceful settlers spreading across the continent, clearing fields and erecting homes on empty land. Jacobs identifies the ultimate goal of settler colonialism as the acquisition of land. ${ }^{20}$ The reality was that the land was not empty, and settlers took land from Indians through treaties, and when that was not possible, by outright violence..$^{21}$

Through his third wife and subsequent family, Kautz participated in the increased settling of the West and the spread of eastern American metropolitan culture and values. His time in the southwest displays the violent nature of colonization. August and Fannie were agents of colonization, and Kitty's story exemplifies an Indigenous woman's reaction to her changing world. Not only does Kautz's story mimic many others of his time but, more distinctly, his relationship to his various wives represents the role women held in society and within the structure of colonization. Kitty, as an Indian woman, recognized that her choices secured her survival and increased the opportunities available to her children. Conversely, in a time of uncertainty within Victorian-era middle class and confined by social standards of femininity, Fannie, a white woman, worked to maintain her standard of living at western military posts. Both of these women, in turn, and in vastly different ways, tell the story of colonization through their relationships with August.

\footnotetext{
${ }^{20}$ Margaret D. Jacobs, White Mother to a Dark Race: Settler Colonialism, Maternalism, and the Removal of Indigenous Children in the American West and Australia, 1880-1940, (Lincoln: University of Nebraska Press, 2009), 4.

${ }^{21}$ Walter L. Hixson, American Settler Colonialism: A History, First ed. (New York, NY: Palgrave Macmillan, 2013), 66.
} 
My primary interest lies in the lives of August's wives; however, there are no letters, diaries or other primary sources that come directly from these women. Documenting the lives of women is difficult in itself, but documenting the lives of Native women has proven even more difficult--a common problem when it comes to writing women's history. While Fannie had an active social life and held more of a presence outside of August's journals, very little can be ascertained about who these women were, or how they felt about August. This is especially true for Kitty. There are no sources from their point of view. By using the journals and letters meticulously maintained by August Kautz throughout his life, and by utilizing other records, I hope to examine the roles each woman had in both August's life and colonization. The majority of my research stems from the Kautz Collection located at the Library of Congress, which included nine boxes of primary source materials: scrapbooks, correspondence, military orders, and August's journals ranging from $1853-1895$. While there are some gaps in his journals, we are given a nearly daily insight into August's life over a forty-two year period. August's journal entries, averaging about six to ten sentences, mostly report on the daily happenings regarding his military assignments. An incomplete draft of his autobiography is included in the materials, as well as personal letters that highlight his intimate relationships, and correspondence with other military leaders. The scrapbooks contain newspaper clippings from pivotal moments in his life and military career: the trial of Chief Leschi while he was stationed at Fort Steilacoom in Washington Territory, the Civil War, the theater 
group his wife Fannie participated in while stationed at Fort Whipple, Arizona, and highlights of the family's European trips.

I will focus on two of his three wives, Kitty and Fannie. Charlotte, his second wife, does not warrant the same level of critical analysis. His sentimental attachment certainly shaped his future relationships and she seems to be the true love of August's life, but she died after just three years of marriage and their union yielded no children.

My thesis places the Kautz family within the context of colonization while examining the complicated nature that race, class, and marriage had on his wives and families in the 19th Century American West. Two diverse family structures shaped by societal expectations, racial hierarchies, and Kautz's military duties. My thesis is important because it evaluates the experiences of women--white and Native--in the West, focusing on the ways in which they used intimate relationships with the United States military officers to assert power and agency in their changing worlds, and within a complex and interracial extended family structure.

My first chapter examines the relationship between August and Kitty. August and Kitty's relationship was not unheard of in the 19th Century, nor was Kautz, an officer in the United States military, alone in having a relationship with an Indian woman. The partnerships were integral to trade relationships and settlement. Indigenous tribes saw intermarriage as a way to integrate newcomers 
into society. ${ }^{22}$ August's journals provide a glimpse into Kitty's life, struggles, and happiness; hers is a story shaped by colonization, Manifest Destiny, and by her connection with August Kautz. Living in the footnotes of others' stories was a daughter, wife, and mother. By tracing her life through her father, husbands, and children, I hope to fill in the gaps of her story. This includes, first and foremost, my struggles with determining how to even address or refer to Kitty. Through my research of Indigenous women, I discovered that many names were often associated with one individual, and used at different times, and for different reasons. Candace Wellman's extensive research into the Indigenous wives of settlers in Washington Territory highlighted the same common problem. ${ }^{23}$ Laurie Arnold's article, "More than Mourning Dove: Christine Quintasket--Activist, Leader, Public Intellectual," examines the many names used by the article's subject, Quintasket, throughout her life. "Quintasket's fluid use of her names illustrates the ease with which she concurrently occupied multiple identities, a practice that allowed her to navigate the overlapping Colville and Western worlds." 24

22 David Peterson Del Mar, The American Family: From Obligation to Freedom, Rev. edition, (New York: Palgrave Macmillan, 2011), 9. Peterson Del Mar's work analyzes American family structures from colonial times, he argues that even within all the variations of "place, race, status and circumstance, North Americans shared a common endeavor: restoring social equilibrium through the use of family, kin and neighbors" (23).

${ }^{23}$ Candace Wellman's Interwoven Lives: Indigenous Mothers of Salish Coast Communities \& Peace Weavers: Uniting the Salish Coast through Cross-cultural Marriages examines the relationships between white settlers and their Indigenous wives in the Puget Sound region. Wellman breaks down stereotypes of interracial marriages and examines the diverse ways these women adapted and endured the changing world around them as settlement increased in the region. Wellman reconstructs the forgotten history of the Puget Sound towns that often ignore the Indigenous wives of their founding fathers.

${ }^{24}$ Laurie Arnold, "More than Mourning Dove: Christine Quintasket-Activist, Leader, Public Intellectual," Montana the Magazine of Western History 67, 1 (Spring 2017), 28. 
Finding Kitty's name, and how she might have used her own identity to navigate her changing world, was a journey filled with ambiguity and, frankly, guesswork. When I first read of August's Indian wife, she was called Kate. ${ }^{25}$ As I delved more into the research, I learned she was born Tenas Puss and later adopted the name Kitty Etta--a rough, Christianized translation of Tenas Puss. ${ }^{26}$ Throughout his journals, August refers to her as Kate, Etta, K, or simply as his "friend." A footnote in a report conducted by the Bureau of Indian affairs notes that one of her sons referred to her as Ada. In a 1917 petition, August "Gus" Kautz claimed to be the son of Lieutenant August Kautz and Ada Lashmeer."27 Her story is further complicated by the confusion of her names, and it was hard to determine with which name she most identified. For consistency, I knew I needed to pick one version. I did not want to do her an injustice by using a name placed upon her by a man who abandoned her, nor did I want to assume those names were only attached to her by August. An interview conducted by Fred Lockley with Nugen Kautz, Kitty's eldest son, gave the most satisfying answer, "My mother was born at Nisqually. After she was married, she never went by her Indian name anymore but always went by Kitty Kautz." 28 My first instinct was to

${ }^{25}$ Sinclair, "Part I, 'Our Manifest Destiny Bids Fair for Fulfillment,"” 70. I came across August and Kate while doing research for The National Park Service for a Historical Resources Study at Fort Vancouver starting in Fall 2015.

${ }^{26}$ Kautz, Biography of a Civil War General, 51.

27 United States Department of the Interior, Office of Federal Acknowledgement, "Summary Under the Criteria and Evidence for Proposed Finding Steilacoom Tribe of Indians," January 14, 2000, https://www.bia.gov/sites/bia.gov/files/assets/as-ia/ofa/petition/011_steila_WA/011_pf.pdf (Accessed May 20, 2018), 63, 90.

${ }^{28}$ Fred Lockley, Interview for Oregon Journal, January 19, 1925, "Biography - Kautz, Nugen," Vertical File, Main floor, Oregon Historical Society. 
call her Tenas Puss, or Tenas, as it was the name given to her at birth. However, I am not telling the story of Tenas Puss' birth, I am telling the story of her adult life, so it seems appropriate to call her by the name she lived most of her life with, which I have determined to be, and will henceforth refer to her as - Kitty.

While I may not ever know how Kitty truly felt about her name, I can begin to outline her story through the lives of those around her. While her story is hard to trace, she was related, according to most sources, to Chief Leschi, a prominent leader in the Puget Sound Indian War, and prisoner of Lieutenant Kautz while he was stationed at Fort Steilacoom. Some sources indicate that Leschi's brother Quiemuth was Kitty's father, but even her parentage is surrounded by ambiguity. Though we may not know whether this familial connection to Leschi led to the relationship between August and Kitty, it is evident that they were brought together by Leschi's role in the Puget Sound Indian War. None of my research led to any satisfying answers about Kitty's life, but it did illuminate her story as one that shaped her personal autonomy and determined the lives and opportunities for her and her sons.

In my second chapter, I look at August's third marriage with Fannie Markbreit, a woman twenty years younger than him. The relationship dynamics were vastly different from what he had with Kitty. Fannie was a middle-class white woman, whose affluent family members provided her with opportunities throughout her life. The details of her early years are minimal, as was the case with Kitty. Despite this, Fannie's story is easier to trace--unlike in Kitty's situation, 
the identity of Fannie's parents is certain, and we also know she had siblings. August mentions visiting Fannie at her sister's house, and her brother was Leopold Markbreit. ${ }^{29}$ August wrote in his journal that Miss Markbreit was the halfsister of his acquaintance Fred Hassaurek. ${ }^{30}$ Her family and movements are easily traced, so there are fewer questions about her life before August. As the wife of an officer, she traveled west with August and asserted her independence and autonomy by participating in local theater and navigating her own way through the ups and downs of her relationship with August. Fannie and August's relationship reflects all of the happiness, hardships, and struggles of a married couple - financial strain, children, loss, and suspected infidelity. Through their marriage and their movements within the military, we can examine their relationship and trace the impacts of American colonization as settlement and military presence increased.

Lastly, I conclude my thesis with an analysis of the fates of August's two families after his death. The role he held within each family unit was unique, each with its own structure shaped by broader cultural influences. August and Fannie benefited from their roles in colonization. Kitty, reacting to her changing world, made choices that would benefit her and her sons. After August's death, the legal

${ }^{29}$ Kautz, Biography of a Civil War General, 195-196. Leopold Markbreit was an affluent member of Cincinnati, Ohio becoming Mayor in 1907. He was a lawyer, newspaper owner, ambassador and journalist throughout his life. A connection, which would benefit August and Fannie throughout their marriage.

30 Ibid., 194. 
system set up to protect Fannie and her family would offer no benefits for August's eldest sons.

I hope to reconstruct the stories of the women in August's life while they navigated a changing and complex world--a challenge proving most difficult with his first wife, and much easier with his third. The complex relationships August forged throughout his life were shaped and defined by race, class, and societal expectations.

In an effort to be consistent with terminology, I will refer to August Kautz as August when referencing his personal relationships, and Kautz when referencing his military accomplishments. I do not refer to his wives as Mrs. Kautz, as that would create confusion for the reader. Additionally, I refer to the Hudson's Bay Company as HBC to avoid repetition. The eldest son of August and Kitty was named Nugen, but August often refers to him as Lugie in his journal. Their second child was named Augustus, but the elder August refers to him as Doctin, and his brother Nugen refers to him as Gus. I refer to people of Indigenous tribes by their tribal names when addressing them specifically, and Indian, Indigenous, or Native generally. August was inconsistent with dating his journals; I have standardized all dates to be the same, and indicated my changes within brackets. I have provided timelines within each chapter to help understand the change over time and place the Kautz family in context with the events examined. 


\section{Chapter One}

\section{"After the Manner of My Mother's People": Washington Territory, 1853-1861}

\section{Fort Steilacoom, Washington Territory - 1859}

The rain fell steadily into the muddy earth, the sun covered by gray sky. $A$ Nisqually woman, belly swollen with pregnancy, began to feel the pangs of birth. She was in the comfort of one of the completed officer's quarters, amid a halfbuilt fort, established years earlier for the United States military. The Indian reservation nearby was home to members of the Nisqually Tribe. The incomplete buildings were being constructed by the American soldiers meant to occupy them. An old Lummi midwife helped as the woman's labored breathing began to guide the baby into the world. The woman sent away the midwife as she grew dissatisfied, and after an hour's labor, she asked for a doctor to be sent for instead. The father, an American officer, called for his friend Dr. Berrien and the child was delivered shortly after. The woman lay recovering, and the baby cooed softly, nestled warmly in his mother's arms. ${ }^{31}$

Not much is known about the life of Kitty before and after her marriage to August Kautz. Drawn from August's journal, and the stories from her two children, we get a glimpse into Kitty's life. Questions about Kitty's identity and the life she lived are incompletely answered by the people who presumably knew her best. Nugen, the eldest of Kitty and August's sons, details his family history--both from his mother and father's side--in an interview with Fred Lockley published in the Oregon Journal dated January 1925. Nugen presents himself as a proud descendant of two strong lines of warriors. When recalling his parent's marriage, he describes his mother, as "...not only the Chief's daughter but she was a very attractive girl." 32 In a letter to Eva Emry Dye, Edward Huggins examines August's

\footnotetext{
${ }^{31}$ August V. Kautz, Journal, February 9, 1859, Boxes 1-3, August V. Kautz Papers, Manuscript Division, Library of Congress, Washington, D.C.. All further journal entries will be cited as A.V.K Journal, followed by the date of the entry.

${ }^{32}$ Lockley, "Biography - Kautz, Nugen," Oregon Historical Society.
} 
relationship, stating, "...the Indian woman, Kitty, was quite good looking." 33 Edward Huggins was an $\mathrm{HBC}$ employee at Fort Nisqually and close friend of August. Huggins married Letitia Work, the half-Indian daughter of HBC trader John Work, in $1857 .{ }^{34}$ Huggins' relationship to Kautz gave him access to the most intimate details of his life, and Huggins' own marriage to an Indian woman indicates there was a parallel in the men's lives. Besides her physical descriptors, there are no records of what Kitty was like. She kept no known diaries and her history can only be traced through the men in her life, her father, husbands, and sons.

Based on census data, Kitty was 45 in 1887, meaning she was born around 1842. Her sons' ages, also listed in the census data are 29 and 27, so Kitty was around16 when she gave birth to Nugen, and 18 when she gave birth to Augustus or Gus. ${ }^{35}$ In the interview with Lockley, Nugen states, "she was just a girl when my father married her." ${ }^{36}$ Along with the ambiguity surrounding the origins of her relationship with August, and her name, there is conflicting information regarding her parentage. Her son states she was the niece of Chief Leschi, a prominent Nisqually leader, and that much seems to be consistent

\footnotetext{
${ }^{33}$ Edward Huggins, Letter to Mrs. Eva Emery Dye, February 1, 1904, "Biography - Kautz, A.V." Vertical File, Main floor, Oregon Historical Society. Eva Emery Dye was an Oregon City, OR based historian and author of regional history and literature. For more information on her see; Sherri Bartlett Browne, Oregon Encyclopedia, "Eva Emery Dye (1855-1947)," https://oregonencyclopedia.org/articles/dye eva emery/\#.XO1lolhKiUk, (Accessed May 26, 2019).

${ }^{34}$ Cecelia Svinth Carpenter, Maria Victoria Pascualy and Trisha Hunter, Nisqually Indian Tribe (Charleston, SC: Arcadia, 2008), 14.

351887 United States Census, King County, Washington State \& Territorial Census, 1857-1892. Digital Image available at Ancestry.com.

${ }^{36}$ Lockley, "Biography - Kautz, Nugen," Oregon Historical Society.
} 
among sources. ${ }^{37}$ Candace Wellman emphasizes that officers had a tendency to marry into prominent Indigenous families, "officers at Fort Steilacoom and other posts had married Indigenous women by tribal custom, including future general Phil Sheridan's union with a Grande Ronde tribal Chief's daughter. Lieutenant August Kautz married an equally important Nisqually woman." ${ }^{38}$ Much like her name, tracking Kitty's lineage is yet another example of how difficult it is to trace Native women in the nineteenth century--even one whose father may have been a prominent tribal member. On the other hand, it is often easy to trace the children of prominent white male figures in history.

Kitty's life did not begin with marriage, and to understand Kitty's world before meeting August seemed important to comprehend the effects that colonization had on her life. However, even the records indicating who her father was intertwined with August's own story. The evidence led to two differing-though sometimes intersecting--paths. Two different men are identified in various sources as Kitty's father: Quiemuth, the brother of Chief Leschi, and Lashmere, whose own identity is filled with uncertainty among sources. ${ }^{39}$

Historian Lisa Blee offers evidence that Quiemuth was Kitty's father, "Recognizing the army personnel as men of authority, Quiemuth married his daughter "Kitty" to Lieutenant August Kautz, and Leschi's daughter Kalakala

\footnotetext{
${ }^{37}$ Historians Lisa Blee, and Cecelia Svinth Carpenter all cite Kitty as the niece of Chief Leschi. ${ }^{38}$ Candace Wellman, Interwoven Lives: Indigenous Mothers of Salish Coast Communities, (Pullman, Washington: Washington State University Press, 2019), 190.

39 The only other reference I found in my research was a connection between "Lachmere" and Nisqually Chief Lahalet. They accompanied Dr. Tolmie on an excursion to Mount Rainier, or Tacobet, in 1833. Lachmere is cited as Lahalet's nephew.
} 
married settler Charles Eaton." ${ }^{0}$ In the interview with Lockley, Nugen stated his mother Kitty was born to Chief Lashmere, chief of the Nisqually tribe on Puget Sound. ${ }^{41}$ Further evidence from the interview suggests Kitty's father was present at the time of the ceremony. "They were married after the manner of my mother's people; that is, my father gave a certain number of ponies, blankets, etc., to my mother's father for her, and my mother's father gave a wedding feast to which all of my mother's relatives were invited and my mother and father ate from the same dish and drank from the same cup." Nugen explained that the recognition in front of witnesses by a man and woman in this manner constituted a marriage ceremony among Indians. ${ }^{42}$

Nugen's reference to his parents' marriage ceremony provides little insight into when the two were married but indicates Kitty's father was alive and present at the ceremony. Nugen also describes his Grandfather's stance on peace with the whites. "When some of the other chiefs counseled war, my grandfather said, 'there is no use fighting against the white men. It would do no good, for they are like ants in an anthill, where they come from there are so many." 43 His grandfather's cousin shot him for counseling peace. ${ }^{44}$ Such evidence would suggest that her father was not Quiemuth, who was a leader in the Puget Sound Indian Wars after hearing the terms set forth during the Medicine Creek Treaty,

\footnotetext{
${ }^{40}$ Lisa Blee, Framing Chief Leschi: Narratives and the Politics of Historical Justice, (First Peoples (2010). Chapel Hill: University of North Carolina Press, 2014), 88.

${ }^{41}$ Lockley, "Biography - Kautz, Nugen," Oregon Historical Society.

42 lbid.

${ }^{43}$ Ibid.

44 lbid.
} 
but rather Lashmere. This reference indicates that he might not have participated in the fighting, which would have allowed him to be present at the marriage ceremony Nugen described.

August was at Fort Steilacoom in 1853 before the start of the war in 1855 , and it is possible that they may have met at this time, allowing Quiemuth to be present at the wedding; however, it seems more plausible that he married Kitty at his second return to Fort Steilacoom during the Puget Sound Indian War in 1856. Quiemuth could not be present in 1856 for a wedding, having fled with his brother Leschi when Governor Mason issued arrest warrants for Leschi and Quiemuth to bring them into custody. ${ }^{45}$ While the social and political environment of the Puget Sound Indian War makes it unlikely that Quiemuth, brother of Leschi, would marry his daughter to Lieutenant Kautz during wartime, the complex nature of settler-Native relationships does make it possible that a member of the Nisqually Tribe--one who was not a prominent leader in the Puget Sound Indian War-would allow for a marriage to an officer in the United States military. Decades of intermarriage had created a complex society with competing loyalties; during and after the war, territorial and military authorities relied on alliances with Natives. ${ }^{46}$ Though the exact date is unknown, and Nugen does not clarify in the interview, it seems his grandfather's death occurred after Kitty's marriage to August, and

\footnotetext{
${ }^{45}$ Cecelia Svinth Carpenter, The Nisqually--My People: The Traditional and Transitional History of the Nisqually Indian People, (Tacoma, Wash.: Tahoma Research Service, 2002), 170. ${ }^{46}$ Lorraine McConaghy, and Center for the Study of the Pacific Northwest, Warship under Sail: The USS Decatur in the Pacific West, Emil and Kathleen Sick Lecture-book Series in Western History and Biography; 15, (Seattle: Center for the Study of the Pacific Northwest: in Association with University of Washington Press, 2009), 111 \& 140.
} 
Quiemuth surrendered himself to authorities and was murdered in $1856 .{ }^{47}$ Further evidence found in a report submitted to the Secretary of the Interior for Federal Acknowledgement stated that Lashmere married a daughter of John Yateko and that he was the father of Kitty. ${ }^{48}$ In the same report, her son Gus referred to her as Ada Lashmeer, her surname indicating a paternal connection to the name Lashmere. In consideration of where the evidence is coming from and despite the conflicting information, those closest to her named her father as Lashmere.

\section{The Nisqually People \& the Puget Sound Indian War}

Our knowledge of the Nisqually tribe's history can greatly be attributed to Cecelia Svinth Carpenter, a Nisqually tribal member, and historian who devoted much of her life to documenting the history of her people. The Nisqually are part of the Southern Coast Salish, a network of smaller groups connected by waterways. ${ }^{49}$ To ensure positive trade relations, intermarriage was common between tribes; the Nisqually would intermarry frequently with the Klickitat, a tribe east of the Cascades. ${ }^{50}$ Members of the Nisqually tribe lived in thirteen villages surrounding the southern part of Puget Sound near present-day Olympia, Puyallup, Tacoma, and Mount Rainier, known as "Tacobet" to the Nisqually

\footnotetext{
${ }^{47}$ United States Department of the Interior, "Summary Under the Criteria and Evidence for Proposed Finding Steilacoom Tribe of Indians," 35.

48 Ibid., 25-26.

${ }^{49}$ William C. Sturtevant, Handbook of the North American Indians. Vol. 7, (Washington: Smithsonian Institution, 1978), 485.

${ }^{50}$ Herman Karl Haeberlin, and Erna Gunther, The Indians of Puget Sound, University of Washington Publications in Anthropology; v. 4, No. 1, (Seattle, Wash.: University of Washington Press, 1930), 11.
} 
people. ${ }^{51}$ They hunted and gathered seasonally, their lands extending from the head of Puget Sound to the east of Mount Rainier. ${ }^{52}$ The Nisqually River flowed through their expansive lands, connecting most of their villages and providing fresh water and salmon. ${ }^{53}$ In the winter months, they lived in cedar plank longhouses, permanent structures with removable roof sections which allowed for light and smoke ventilation, and which could house several families. ${ }^{54}$ In the summer months, they lived in temporary teepees, or shed-type structures consisting of a framework of poles and matting tied down, that allowed for easy transport. ${ }^{55}$

The division of labor separated men and women's spheres. Women gathered berries and roots and dug up wild potatoes. ${ }^{56}$ In the summer, women worked to prepare houses for the colder weather and then spent the winter months making clothes, cradleboards, and cooking utensils. ${ }^{57}$ Men did not participate in housework; they were not expected to cook, sew, or look after children. Their responsibility was to stay fit and be ready to fight, as they were responsible for the protection of the village and the safety of their families and the rest of the inhabitants. In addition to protection, they were to provide food for their

\footnotetext{
${ }^{51}$ Carpenter, Nisqually Indian Tribe, 7.

${ }^{52}$ Haeberlin, The Indians of Puget Sound, 7.

${ }^{53}$ Carpenter, Nisqually Indian Tribe, 7.

${ }^{54}$ Cecelia Svinth Carpenter, Fort Nisqually: A Documented History of Indian and British Interaction, (Tacoma, Wash.: Tahoma Research Service), 1986, 3.

${ }^{55}$ Carpenter, The Nisqually--My People, 38.

${ }^{56}$ Haeberlin, The Indians of Puget Sound, 20.

${ }^{57}$ Carpenter, Fort Nisqually, 10-11.
} 
families by fishing and hunting. ${ }^{58}$ The Nisqually also had access to clams as part of their food source. ${ }^{59}$ Among the Coast Salish, the wealthiest house head was generally the acknowledged leader. ${ }^{60}$ The tribal leaders were known as a headsman, and they were in charge of their village group. This role was often hereditary, but if no eligible or capable male heir was available, one was chosen through popular support. 61

Chief Leschi was born in 1808; an esteemed member of the Nisqually tribe, often sought out for his advice in major decisions. ${ }^{62}$ Leschi, while not actually a chief, was attributed that title due to his matrilineal connections and wealth. ${ }^{63}$ Previously among the Nisqually, there was only a tribal leader in times of war, and the title only lasted for the duration of the war; the title "chief" was not used until the arrival of the British and Americans. ${ }^{64}$

Leschi and his brother Quiemuth were born to a wealthy Nisqually man. Leschi's mother was the daughter of a high-ranking Klickitat, a kin connection that gave Leschi connections and access to resources across the Cascade Mountains, leading to his own wealth status. ${ }^{65}$ The Nisqually tribe had a history of

\footnotetext{
58 Ibid., 11.

${ }^{59}$ Haeberlin, 20.

60 Sturtevant, 494.

${ }^{61}$ Carpenter, Fort Nisqually, 15.

62 Blee, Framing Chief Leschi, 87-88.

63 lbid.

${ }^{64}$ Carpenter, Fort Nisqually, 15.

${ }^{65}$ Blee, 87-88.
} 
trading with the Klickitat and Yakamas on the eastern side of the Cascade Mountains. ${ }^{66}$

The British HBC established Fort Vancouver on the Columbia River in 1824, in present-day Vancouver, Washington, to expand their fur trading empire. At the time, the Chinook people occupied the lands on either side of the Columbia River. ${ }^{67}$ In 1833, the HBC established Fort Nisqually as another fur trading post. The presence of the $\mathrm{HBC}$ led to a rise in agricultural development in the region surrounding Fort Nisqually from 1838-1841. With the increased presence of fur traders, the daily life of the Nisqually people slowly began to shift. ${ }^{68}$ Leschi and Quiemuth, like many Indians, saw the potential for a reciprocal trade relationship between their tribe and the HBC. Yet neither the Nisqually people nor the British realized the lasting consequences that the British presence would have. As more British--and later Americans--arrived in the area, the Nisqually realized their homelands were part of Oregon Territory, and that the British and Americans had agreed to occupy the lands together.

Fort Vancouver became a staging point for American settlers; along with the increased settlement and declining fur trade, the HBC began to lose control of the region. In 1843, a provisional government of settlers, missionaries, and retired fur traders formed in Oregon Territory. John McLoughlin, Chief Factor of the HBC at Fort Vancouver, refused to acknowledge its legitimacy. Despite this,

\footnotetext{
${ }^{66}$ Carpenter, Fort Nisqually, 18.

67 Sinclair, 2.

${ }^{68}$ Carpenter, Fort Nisqually, 96.
} 
the provisional government began drafting a constitution and lobbying the United States Congress for territorial status. ${ }^{69}$ The 1845 election of James Polk was a monumental moment in American history and not just for Texas--President Polk declared Oregon Territory for the United States, his declaration stemming from Manifest Destiny. He desired American expansion to link the United States from coast to coast, and Americans thought that it was their divine right. ${ }^{70}$

Britain and the United States began a territorial contest for rights to the region. The contested lands divided along the 49th parallel, the region making up the modern United States border with Canada. The Oregon Treaty of 1846 ensured American presence for everything south of the 49th parallel and placed the Nisqually lands under the United States domain. ${ }^{71}$

A culmination of events led to increased military presence, and the appointment of Lieutenant Kautz to the Pacific Northwest. Early settlers and missionaries were among the Americans who stopped at Fort Vancouver prior to reaching their main destination. One such group included the Whitmans and Spaldings. They arrived at Fort Vancouver and received the help and hospitality of the $\mathrm{HBC}$ before settling in Eastern Washington and establishing Protestant missions among the Cayuse and Nez Perce near Fort Walla Walla. After 1846, the number of white settlers in the region nearly doubled. ${ }^{72}$

\footnotetext{
${ }^{69}$ Sinclair, 7.

70 Ibid., 8.

${ }^{71}$ Carpenter, Nisqually Indian Tribe, 7.

${ }^{72}$ Cameron Addis, "The Whitman Massacre: Religion and Manifest Destiny on the Columbia Plateau, 1809-1858," Journal of the Early Republic 25, no. 2 (2005), 231-232, 240.
} 
In 1847, due to widespread disease and cultural misunderstandings, a small Cayuse band attacked the Whitman mission when a measles outbreak ran through the Cayuse tribe, which killed nearly half the population within two months. Noticing that the Americans treated by Dr. Whitman mostly survived, the small band took action, killing the Whitmans and eleven others, and held a group of hostages that were later released when the HBC's Peter Skene Ogden initiated talks and traded goods and supplies for the hostages. ${ }^{73}$ The anger was distinctly directed at the Americans, as a French Catholic mission nearby remained unharmed. The Whitman incident caused much distrust between Indians and settlers and would have lasting impacts on relations in the region. While the violence of the attack was no more extreme than others committed in the following decade by both Indians and Americans, labeling the murders of the Whitmans a "massacre" gave American settlers the moral responsibility to tame the land, and accentuated the trope of barbaric Indians and justified their removal from the lands. ${ }^{74}$ Prior to the Whitman Massacre, relations were generally peaceful; Indians provided labor and their knowledge and understanding of the region. Disease began to decimate the populations first, yet hostilities remained few--it was not until their lands were taken away that violence erupted. Indian removal threatened the way of life for many tribes, and many deemed the proposed treaties unfair.

\footnotetext{
73 Sinclair, 10-12.

${ }^{74}$ Addis, 249.
} 
While President Polk claimed Oregon for the United States, and the military increased their presence in 1849 , the HBC announced plans to move their regional headquarters from Fort Vancouver on the Columbia River to Vancouver Island in present-day Canada. ${ }^{75}$

On May 13,1849 , American military forces arrived by sea at the HBC site at Fort Vancouver on the Massachusetts. ${ }^{76}$ The military's arrival led to the establishment of military headquarters alongside the existing HBC post under the leadership of Major Hathaway. ${ }^{77}$ Vancouver Barracks was a strategic military site, serving as the main point of contact for other military forts in the region. Eight officers and 152 enlisted men, along with a few wives and children, made their home in Vancouver. They dined and socialized with the HBC and attended local Catholic and Protestant churches. The arrival of the Mounted Rifleman in October 1849 increased the need for more housing, and the troops set forth establishing Vancouver Barracks as the epicenter of military society and government explorations in the region, eventually established as the regional headquarters under the Pacific Division in California. When the British completed their move to Canada, the garrison at Vancouver Barracks took over most of their lands and buildings. ${ }^{78}$

\footnotetext{
75 Sinclair, 8.

76 Ibid., 14-15.

77 Thomas W. Prosch, "The United States Army in Washington Territory," The Washington Historical Quarterly 2, no. 1 (1907), 29.

${ }^{78}$ Sinclair, 15-19, 40.
} 
Just as they had done in Vancouver, the United States military established Fort Steilacoom in 1849 alongside the British HBC's Fort Nisqually, five miles east of a Nisqually village. ${ }^{79}$ Captain Hill was in charge at Fort Steilacoom, located north of Fort Vancouver and south of Seattle. ${ }^{80}$ One company of soldiers initially occupied the fort, and they were housed in "wooden shells of houses and log cabins." 81 Increased military presence led to expanded American settlement in the Puget Sound region. William F. Tolmie served as the Chief Trader at Fort Nisqually. Under his direction, the main source of revenue was not furs, but sheep's wool and cattle. Fort Nisqually also served as a trading center for the incoming settlers, who grew dependent on the fort for supplies. ${ }^{82}$

Congress created Oregon Territory on August 14, 1848. ${ }^{83}$ Two years later the Oregon Donation Land Claim act passed by U.S. Congress in 1850 gave land to white, male citizens, or those willing to become citizens. American men in Oregon could claim 320 acres for themselves and 320 for their wives. New settlers could claim half of that amount. ${ }^{84}$ The growing population led to a restructuring of the territory lines in the Pacific Northwest region. On February 8, 1853, Washington became a territory and established a territorial government,

\footnotetext{
${ }^{79}$ Carpenter, Nisqually Indian Tribe, 7.

80 Prosch, 29.

${ }^{81}$ Ezra Meeker, Pioneer Reminiscences of Puget Sound: The Tragedy of Leschi, (Lowman \& Hanford Stationery and Printing, 1905), 51.

82 John S. Galbraith, "The British and Americans at Fort Nisqually, 1846-1859," The Pacific Northwest Quarterly 41, no. 2 (1950), 110.

${ }^{83}$ William Lang, Oregon Encyclopedia,"Creation of Washington Territory, 1853," https://oregonencyclopedia.org/articles/washington_territory_1853/\#.XRp2G-hKiUk, (Accessed June 28, 2019).

${ }^{84}$ Peggy Pascoe, What Comes Naturally: Miscegenation Law and the Making of Race in America, (Oxford, England; New York, NY: Oxford University Press, 2009), 78.
} 
with Isaac Stevens named Governor. ${ }^{85}$ Isaac Ingalls Stevens, a West Point graduate, accepted the position of territorial governor and, along with it, the title of Superintendent of Indian Affairs. ${ }^{86}$ While balancing his dual duties, Stevens asserted his connections and powers in order to bring a railroad to the Pacific Coast, following the 49th Parallel. ${ }^{87}$ His desire for rail lines undoubtedly influenced his other responsibilities, including the division of lands between Indians and settlers. Stevens fully believed the solution to the "Indian Problem" was relocation to reservations and the eventual decimation of the race. ${ }^{88} \mathrm{His}$ appointment as governor and superintendent would have lasting and destructive consequences for the region, particularly for the relationships between the settlers, the government, and the Indigenous populations.

Kautz, newly arrived at Fort Vancouver in 1853, received a new assignment to Fort Steilacoom in March which only lasted a few months, and was mostly spent exploring the surrounding area, and visiting other forts in Washington Territory before he was transferred down to Oregon to fight in the Rogue River Wars in July. ${ }^{89}$

Stevens quickly set out to establish treaties with various local tribes in an effort to obtain land rights for settlers, and to minimize Native presence in

\footnotetext{
${ }^{85}$ Carpenter, Nisqually Indian Tribe, 7.

${ }^{86}$ Sinclair, 29.

${ }^{87}$ Hyde, Empires, Nations and Families, 422.

${ }^{88}$ Kautz, Biography of a Civil War General, 29.

89 Unpublished Draft of Autobiography, Box 8, August V. Kautz Papers, Manuscript Division, Library of Congress. Washington, D.C..
} 
Washington Territory. The Medicine Creek Treaty was the first made. ${ }^{90}$ When Stevens convened treaty talks, he attributed the titles of Chief and Sub-chief to brothers Quiemuth and Leschi. While Leschi and Quiemuth's kinship and wealth status reflected their leadership positions in society, British and American political ideals attributed the titles of Chief and Sub Chief to the brothers. ${ }^{91}$ The wealth status of the brothers gave them a position of leadership within their tribes as part of the Coast Salish tradition of attributing leadership to those with high status, wealth was determined by one's ability to provide for their family, and fulfill responsibilities outside of their community. ${ }^{92}$ Leschi and Quiemuth were known for their wealth, and their past efforts to connect and create relationships with the HBC when they arrived in 1833, and again when the United States Military arrived in $1849 .{ }^{93}$

Stevens brought tribal leaders from other local tribes, including the Puyallup, to establish three reservations. 600 men, women and children were present at the Medicine Creek Treaty in December $1854 .{ }^{94}$ Prior to the start of the Puget Sound Indian Wars, there were an estimated 2,000 Nisqually people in total. ${ }^{95}$ Stevens refused to have interpreters, instead insisting on using Chinook Jargon to negotiate. ${ }^{96}$ Chinook Jargon was a language used for simple barter

\footnotetext{
${ }^{90}$ Carpenter, Nisqually Indian Tribe, 7.

91 Blee, 106.

92 lbid., 88.

93 lbid.

${ }^{94}$ Meeker, 235.

${ }^{95}$ Haeberlin, 9.

${ }^{96}$ Meeker, 207-208.
} 
between tribes and fur traders, and not appropriate for complex treaty negotiations ${ }^{97}$ Many, including Chief Leschi, were unhappy with the terms set forth, as well as the proposed locations of the reservations. Leschi wanted the people to have land near the water so they could fish. ${ }^{98} \mathrm{He}$ opposed the planned reservation in the high-forested lands to the west of the Nisqually River. Leschi's growing frustrations led him to rip up the commission naming him as sub-chief and to leave. ${ }^{99}$ Leschi's refusal and mounting tensions led to the Treaty War of $1855-1856 .{ }^{100}$ This yearlong campaign brought Kautz to Fort Steilacoom, where his story with Kitty likely began.

As violence erupted over the land, settlers fled to towns under military protection. The rising tensions in Washington Territory finally reached their breaking point. Increased hostilities begin in1855 between Natives and white settlers as the effects of the dramatic changes of recent years began to take their toll. At the same time, a March 3, 1855 law-- "Increase and Better Organization for the Army, and other Purposes"--allowed for the increase in military presence and spending in the Pacific Northwest. ${ }^{101}$ Federal protection of settlers was increasing with the arrival of the U.S.S Decatur in Seattle's Elliot Bay. ${ }^{102}$ Despite opposing the reservation sites, Chief Leschi supported peace and remained

\footnotetext{
97 J. A. Eckrom, Remembered Drums: A History of the Puget Sound Indian War, (Walla Walla, Wash.: Pioneer Press Books, 1989), 4.

${ }^{98}$ Carpenter, The Nisqually Tribe, 7-8.

99 Meeker, 236.

${ }^{100}$ Carpenter, The Nisqually Tribe, 8 \& 31. The Nisqually tribe did not have a written language so there are no written accounts of the Puget Sound Indian Wars, or Treaty War, from their perspective of what happened.

${ }^{101}$ Kautz, Biography of a Civil War General, 29, 31.

102 McConaghy, 109-110.
} 
outside of the violence; however, he did not counsel others against war. As a result, an arrest order was issued for Quiemuth and Leschi on October 22, 1855, by acting Governor Charles Mason (Stevens was in Montana negotiating the Blackfeet Treaty). ${ }^{103}$ Leschi and Quiemuth fled the authorities and joined the fighting. In an effort to apprehend the brothers, the territorial government offered twenty dollars for the heads of enemy warriors, and eighty dollars for a chief; both white settlers and other tribes, mostly from the Snoqualmie and Skykomish tribe, sought the rewards. ${ }^{104}$ In December 1855, the Commander at Fort Steilacoom-- aptly named Lieutenant Slaughter-- was killed, alongside many other soldiers. ${ }^{105}$

It was Slaughter's death that brought Kautz back to Fort Steilacoom. The greatest tragedy of the war occurred in April 1856, when Captain Maxon ordered his soldiers to attack a defenseless Nisqually encampment of mostly women and children. Seventeen died, and many more were injured. ${ }^{106}$ Lieutenant Kautz found survivors of Maxon's Massacre and accompanied them to Fort Steilacoom, ensuring their safety and fair treatment. ${ }^{107}$

Hostilities had generally ceased by October 1856, but Stevens insisted on apprehending Leschi and Quiemuth for trial. ${ }^{108}$ On November 13, 1856, after just

\footnotetext{
103 Charles F. Wilkinson, Messages from Frank's Landing: A Story of Salmon, Treaties, and the Indian Way, (Seattle: University of Washington Press, 2000), 15.

104 Eckrom, 116.

105 Kautz, Biography of a Civil War General, 33.

106 Wilkinson, 17.

${ }^{107}$ Kautz, Biography of a Civil War General, 35.

108 Meeker, 413.
} 
over a year of fighting, Leschi was taken into custody. ${ }^{109}$ Leschi's nephew Sluggia had betrayed his uncle, giving him up for the payment of fifty blankets. ${ }^{110}$ Charles Eaton, Chief Leschi's son-in-law, was also part of the militia that imprisoned Leschi. ${ }^{111}$ The capture marked an end to hostilities in the Puget Sound. ${ }^{112}$ Leschi's brother, Quiemuth, surrendered on November 17, 1856, to James Longmire of Yelm Prairie and they traveled to the Governor's Office in Olympia. While being held there under protective custody, Quiemuth was murdered. ${ }^{113}$ Leschi was subsequently charged with the murder of $A$. Benton Moses and his first trial, held on November 16,1856 , resulted in a hung jury. ${ }^{114}$ Two members of the jury, Ezra Meeker and William Kinkaid, insisted on acquitting Leschi of all charges. ${ }^{115}$ Kautz remained at Fort Steilacoom after the Puget Sound Indian War and was in charge of the imprisonment of Chief Leschi, who awaited his second trial. ${ }^{116}$ The military in command at Fort Steilacoom, including Kautz, thought Leschi should not be tried as a civilian but as a soldier. ${ }^{117}$

\footnotetext{
109 United States Department of the Interior, "Summary Under the Criteria and Evidence for Proposed Finding Steilacoom Tribe of Indians," 35.

110 Eckrom, 153-154.

111 Cecilia Carpenter, Nisqually Indian Tribe, 31.

112 McConaghy, 132. Navy and Army officers both believed the capture of Leschi would end the war, as he was their most formidable opponent.

${ }^{113}$ United States Department of the Interior, "Summary Under the Criteria and Evidence for Proposed Finding Steilacoom Tribe of Indians," 35.

114 Ibid.

${ }^{115}$ Eckrom, 156.

${ }^{116}$ Kautz, Biography of a Civil War General, 36.

${ }^{117}$ Carpenter, The Nisqually People, 8.
} 
The relationship between Kautz and Leschi is unclear. Beyond prisoner and jailer, they seemingly formed a bond of friendship. Lieutenant Kautz was an ardent advocate for Leschi's innocence and release. Leschi had protested the killing of women and children and the destruction of settlements in the war, and Kautz commended him for his intellect and humanity. ${ }^{118}$ As his prisoner, Leschi advised Kautz on his planned ascent of Mount Rainier. ${ }^{119}$

Chief Leschi's second trial was set for March 18, $1857 .{ }^{120}$ While awaiting trial, a newspaper called The Truth Teller was distributed in defense of Leschi's innocence and release. The anonymous publishers, who have since been identified as Lieutenant Kautz, William Tolmie and Frank Clark, among others, only released two issues of the paper. ${ }^{121}$ The focus of the newspaper highlighted that it was physically impossible that Leschi was present at the site of Moses's murder. The second line of defense was that Leschi, a soldier, should not be tried as a civilian since he was an enemy combatant at the time of Moses'

\footnotetext{
118 Meeker, 206.

${ }^{119}$ Eckrom, 15, \& Kautz, Biography of a Civil War General, 48-50. On July 9, 1857 Kautz, and several other soldiers including Fort Bellingham's post surgeon, began their ascent of Mount Rainier, or Tacobet, as it is known to the Nisqually. Wapowety served as their guide at Leschi's recommendation. Members of the party contracted snow blindness and they were low on supplies so they were forced to turn around before reaching the summit. Though they did not reach the top, the route is now one of the most popular to reach the summit of Mount Rainier. Along this route today are the Wapowety Cleaver and Kautz Glacier, named in honor of the parties attempt to summit the mountain.

120 United States Department of the Interior, "Summary Under the Criteria and Evidence for Proposed Finding Steilacoom Tribe of Indians," 35.

${ }^{121}$ Martin Schmitt, "The Execution of Chief Leschi and the "Truth Teller,"' Oregon Historical Quarterly 50, no. 1 (1949), 31.
} 
murder, and he had been granted amnesty when he surrendered to the military forces. ${ }^{122}$

Despite their efforts, the group was unsuccessful in its pursuit of justice. Leschi was executed on February 19, $1858 .{ }^{123}$ Kautz felt a lasting connection to Chief Leschi. He kept multiple scrapbooks filled with articles relating to the trial and fate of Chief Leschi. ${ }^{124}$ While we know Kautz did come to Chief Leschi's defense, he never mentioned in his journal that he did this as a favor to his wife Kitty, or because of a familial connection.

\section{Intermarriage \& Miscegenation Laws}

August and Kitty's relationship was not unheard of in the 19th century, nor was August alone as an officer in having an intimate arrangement with an Indian woman. The British HBC members began intermarrying upon establishing their fur trading posts. In the earliest decades of the company's existence, the HBC established a rule that no Indian women were to be harbored in the posts and that no intimacies were to be formed with Indian women. ${ }^{125}$ While the HBC tried to forbid intermarriage, they could not enforce their rules. ${ }^{126}$ Indians encouraged the formation of marriage alliances between their women and European and

\footnotetext{
122 Schmitt, 31-35.

${ }^{123}$ Blee,5; In 2004, Leschi was exonerated by a Historical Court of Inquiry and Justice that heard arguments to reconsider the legality of the original trial and wartime murder conviction. Leschi was posthumously exonerated.

${ }^{124}$ Scrapbooks, Box 5, August V. Kautz Papers, Manuscript Division, Library of Congress, Washington, D.C.

${ }^{125}$ Van Kirk, Many Tender Ties, 14.

${ }^{126}$ Sylvia Van Kirk, "From 'Marrying-In' to 'Marrying-Out': Changing Patterns of Aboriginal/NonAboriginal Marriage in Colonial Canada," Frontiers: A Journal of Women Studies 23, no 3 (2002), 4.
} 
American traders; a marital alliance created a reciprocal economic and social bond. ${ }^{127}$ Marriage provided access to goods, which in turn enhanced a family's social and economic position. ${ }^{128}$ Historian Van Kirk emphasizes in her work that intermarriage amongst fur trade society and the Native populations was normal and accepted amongst Englishmen, French-Canadian, Scots, and the Hawaiian workers employed by the HBC. ${ }^{129}$ The employees were mostly single men who married women from the neighboring villages, a practice that spread throughout the region. These types of arrangements were normalized by the time the United States military arrived. While it was socially acceptable for white men to enter relationships with Indian women, relationships between white women and Native men were not as accepted, nor as common. ${ }^{130}$ The alliances created through intermarriage of Indigenous women provided some women with the resources to realize personal ambitions amidst social, cultural, and political changes. ${ }^{131}$

\footnotetext{
127 Van Kirk, Many Tender Ties, 8-29.

${ }^{128}$ Melinda Marie Jetté, At the Hearth of the Crossed Races: A French-Indian Community in Nineteenth-century Oregon, 1812-1859, (First Peoples (2010), Corvallis: Oregon State University Press, 2015), 47-48.

${ }^{129}$ Sylvia Van Kirk's Many Tender Ties offers a thorough analysis of interracial relationships in Fur Trade society, focusing on the Canadian West. Van Kirk cites a need for further study and analysis of gender to fully understand the social changes that occurred. Van Kirk also recognizes the lack of sources from women in these relationships, and that their stories - much like Kitty's can only be reconstructed from the writings of the fur traders.

130 This thesis does not analyze the interracial relationships between Native men and white women, for further analysis see: Margaret Jacobs, "The Eastmans and the Luhans: Interracial Marriage between White Women and Native American Men, 1875-1945," Frontiers: A Journal of Women Studies 23, no. 3 (2002): 29-54. This article expands on the distinctly different reactions society had when white women pursued relationships with Native men.

131 Jette, 47-48; Jette's work offers a comprehensive study of French-Canadian fur traders and their Indian wives in Oregon.
} 
The men married Indian women in 'the fashion of the country'--in other words, through common law marriages. ${ }^{132}$ These were essentially marriage arrangements made without the blessing of the church, as there were very few priests around. ${ }^{133}$ Country marriages refer to formal arrangements between fur traders and Indigenous women; these were acknowledged as more than just causal relationships, yet did not constitute the full social and legal benefits of marriage. Attempting to formalize the country marriages, the HBC initiated a policy that required both bride and groom to sign a marriage contract in the presence of witnesses starting in $1821 .^{134}$

There were many types of unions in Indigenous societies, not complicated by the religious and legal ramifications of western society. ${ }^{135}$ Historian Nancy Cott provides analysis on what generally constitutes a socially accepted marriage, "to be marriage, the institution requires public affirmation. It requires public knowledge - at least some publicity beyond the couple themselves; that is why witnesses are required and why wedding bells ring." ${ }^{136}$ Cott's definition of marriage does not specifically apply to Indigenous ceremonies; however, her argument that marriage is based on public affirmation crosses cultural lines. Van Kirk's study of intermarriage in the Canadian West also emphasized this

\footnotetext{
132 Sinclair, 80.

${ }^{133}$ Emma Milliken, "Choosing between Corsets and Freedom: Native, Mixed-Blood, and White Wives of Laborers at Fort Nisqually, 1833-1860." The Pacific Northwest Quarterly 96, no. 2 (2005), 95.

134 Ibid.

135 Kim Anderson, A Recognition of Being: Reconstructing Native Womanhood, (Toronto: Sumach Press, 2000), 82.

${ }^{136}$ Nancy F. Cott, Public Vows: A History of Marriage and the Nation, (Cambridge, Mass.: Harvard University Press, 2000), 1-2.
} 
important aspect in both indigenous and Euro-Canadian society, "a marriage was defined as being openly recognized and characterized by mutual consent, cohabitation, and public repute as husband and wife."137

These relationships, or "country marriages," created trade opportunities and were a valuable part of HBC business. Initially, fur trade marriages in the Puget Sound region followed Native customs and practices, which included the payment of a bride price and did not necessarily entail a lifetime commitment. ${ }^{138}$ The marriages that occurred in Washington Territory from the 1840s-1850s mostly followed the Nisqually custom of the bride moving into the groom's home. As most HBC employees only had the bachelor quarters provided by the company, a temporary Indian village began to grow outside of Fort Nisqually for couples. ${ }^{139}$ The Catholic Church arrived in the Pacific Northwest in the 1830s, and some men chose to legalize their "country marriages" through church sanctioned ceremonies; by the 1850 s, the informal "country marriages" were relatively out of practice. ${ }^{140}$ Intermarriage was integrated somewhat into American culture as settlers and soldiers arrived west, but as more settlers arrived, the increasing numbers of American women made this practice less socially acceptable. Thus, the number of interracial relationships decreased as the social and cultural divide deepened and white settlers increasingly saw

\footnotetext{
137 Van Kirk, "From 'Marrying-In' to 'Marrying-Out,"' 2.

138 Ibid., 4.

${ }^{139}$ Carpenter, Fort Nisqually, 166-167.

140 John A. Hussey, "The Women of Fort Vancouver," Oregon Historical Quarterly 92, no. 3 (1991), 299.
} 
Indians as uncivilized. ${ }^{141}$ Despite the increased presence of American women, some interracial relationships persisted.

Kautz was well aware of his fellow officers' relationships and families. Kautz's journal entry of June 11, 1857 documents interracial relationships, "Fitzhue has two Indian women and a child by each of them. He lives very comfortably." 142 It is notable that Kautz makes no moral comments on Fitzhue's polygamous ways. Fellow West Point classmate and friend of Kautz's, Philip Sheridan, fathered two daughters while at Vancouver Barracks, though Kautz did not know of this until later in life. ${ }^{143}$

George Pickett, a friend of Kautz, also had a child with a Native woman. There was no uncertainty of the child's parentage--Pickett married the woman in both tribal and civil ceremonies, and their son, James Tilton Pickett, was born December 31, 1857. ${ }^{144}$ Kautz's journal entry from January 6, 1858 notes, "Pickett received a little recruit at his post on New Year's eve." ${ }^{145}$ Kautz later wrote of Pickett's son, "Pickett has quite a fine little half breed boy" after a visit to Fort Bellingham. ${ }^{146}$ Shortly after giving birth, Pickett's wife died. Pickett sent his oneyear-old son to live with a family in Mason County, and Pickett later joined the

\footnotetext{
141 Sinclair, 7.

142 A.V.K Journal, June 11, 1857. Candace Wellman's research into Indigenous wives of white settlers explores Fitzhugh and his wives in greater detail in her work Peace Weavers: Uniting the Salish Coast through Cross-cultural Marriages.

${ }^{143}$ Kautz, Biography of a Civil War General, 52. Sheridan's daughter Emma would go on to marry Franklin Olney of Vancouver, Washington. The first cousin of her husband, Eleanor Elizabeth Olney would marry Nugen Kautz, August's eldest son.

144 Sinclair, 83.

145 A.V.K. Journal, January 6, 1858.

146 Ibid., February 24, 1858. "Half-Breed" is now considered a derogatory term, used in this context to reflect the sentiments of the time, not to condone the use of the term.
} 
Confederacy during the Civil War. ${ }^{147}$ Pickett's arrangements created a life for James that allowed him to attend Union Academy, the same school both of Kautz's sons would attend in Olympia, Washington. ${ }^{148}$ James would go on to attend an art school in California and build a career as an artist with the Seattle Post Intelligencer and Oregonian. ${ }^{149}$ James knew his father's identity, but would never reconnect with him as an adult. ${ }^{150}$

The prevalence of interracial relationships led to greater community acceptance. Nancy Cott describes the power of the community in defining marriage--if a community was tolerant of the practices, particularly in the cases of intermarriage, they went on informally even in places where they were prohibited by law. ${ }^{151}$ Peggy Pascoe's national and multiracial analysis of miscegenation laws, What Come Naturally: Miscegenation Law and the Making of Race in America, identifies the power of marriage to "naturalize some social relationships, and to stigmatize others as unnatural." 152

Miscegenation laws are some of the longest lasting racial restrictions in the United States, reflecting the shifts in racial thinking from the 1660 s to the 1960s. ${ }^{153}$ Pascoe identifies the term "anti-miscegenation laws" as an inherently

\footnotetext{
147 Sinclair, 83.

148 Lockley, "Biography - Kautz, Nugen," Oregon Historical Society.

149 Sinclair, 83.

150 Candace Wellman's Interwoven Lives: Indigenous Mothers of Salish Coast Communities examines the relationship of George Pickett, his Indigenous wife and their son James.

${ }^{151}$ Cott, 29.

152 Pascoe, What Comes Naturally, 6.

153 Peggy Pascoe, "Miscegenation Law, Court Cases, and Ideologies of "Race" in TwentiethCentury America," The Journal of American History 83, no. 1 (1996), 49.
} 
racist term, used by lawmakers between 1864 and 1967 to signify the belief that sex and marriage between people of the same race was inherently different from interracial relationships. ${ }^{154}$ Pascoe utilized the term miscegenation to counter this racist ideology. Regulation of interracial marriage and sex existed in nearly every state of the Union; the South had specific regulations regarding Whites and African-Americans, and the West added other prohibited races as the United States expanded. The application of these laws all had one common goal and outcome; they maintained white purity and protected white patriarchal privilege. The laws regulating marriage delegitimized the children born of interracial unions, thus protecting the white race. ${ }^{155}$

While the legal system's control and regulation of interracial marriage reflect general cultural beliefs, it does not always accurately reflect the deepest sentiments of society. The miscegenation laws prevalent in 1855-1868 in Washington Territory, which overlap with Kitty and August's relationship, regulated the marriages that occurred within its borders. The regulation of sex and marriage are important to differentiate. Marriage regulations were more prevalent in the United States. Some states prohibited interracial marriage and sex, but twice as many targeted only marriages. ${ }^{156}$ Marriage implied social benefits to both spouses, and children of these unions were considered

\footnotetext{
154 Pascoe, What Comes Naturally, 13.

155 Jason Gilmer, "Crimes of Passion: The Regulation of Interracial Sex in Washington, 18551950," Gonzaga Law Review Vol. 47:2 (2011/12), 394.

156 Pascoe, "Miscegenation Law, Court Cases, and Ideologies of "Race" in Twentieth-Century America," 49-50.
} 
legitimate and had rights to inheritance from their parents. This was not the case for strictly sexual pairings. Civil court cases cite miscegenation laws in cases concerning marriage, divorce, inheritance, and child legitimacy as frequently as criminal cases regarding sexual misconduct. This evidence suggests that the regulation of marriage established racial boundaries that were considered necessary for the construction of society. The regulation of marriage specifically, and not sex, made it easier for white men to avoid the responsibilities of a legally sanctioned marriage, including the financial support of any children the relationship yielded. ${ }^{157}$ The emerging laws prohibiting interracial marriage reflected the racist sentiments of Washington Territory. The Puget Sound Herald published an article in 1859, which states, "the intermarriage of Whites with Indians is fraught with many serious evils," and the author further wrote that the union led to "an almost instantaneous degeneracy of the White."158 The racist ideology paralleled that of Southerners, who perpetuated the belief that unions between whites and blacks harmed the white individual and the entire race. ${ }^{159}$

As the territorial population increased, the state legislature began to regulate access to marriage. ${ }^{160}$ Washington Territory started regulating marriage when the first legislature passed a law legitimizing all common law marriages.

\footnotetext{
157 lbid.

158 Gilmer, 400-401.

159 Ibid. Gilmer's article expands on the literature of the topic, but cites how it has not been adequately studied and recognizes there is still a significant gap in the research. Washington State's legal history surrounding miscegenation laws is limited in regards to interracial couples, and the subject of interracial relationships in Washington Territory has not been thoroughly or adequately studied. This is partly due to the fact that the only years in which interracial marriages were criminalized was between 1855 and 1868 .

160 Ibid., 395.
} 
This initial application included intermarriages, giving Indigenous wives the rights of inheritance. ${ }^{161}$ Soon after, a succession of amendments attempted to limit intermarriages; a law enacted on January 29, 1855, declared, "[A]ll marriages heretofore solemnized in this territory, where one of the parties to such marriage shall be a white person, and the other possessed of one-fourth or more of negro blood, or more than one-half Indian blood, are hereby void." 162 The language of the law not only prohibited and criminalized new interracial marriages--it imposed a fine between fifty and five hundred dollars--but it also de-legitimized any marriages that occurred prior to $1855 .{ }^{163}$ Washington's 1855 "Color Act" was the first to name "Indian" in a miscegenation law in nearly three decades, which sparked a trend among western states; Nevada passed laws specifying Indians in miscegenation laws in 1861, Idaho in 1864 , and Arizona in $1865 .{ }^{164}$ The Oregon Legislature outlawed marriage between "whites and Indians or halfIndians" in $1866 .{ }^{165}$ Based on these laws, any "country marriages" that occurred during the fur trade era were now voided. The Washington law was repealed in 1868. ${ }^{166}$

There is no data on exactly how many interracial relationships occurred during the course of Washington Territory history. Census data helps provide a

\footnotetext{
${ }^{161}$ Candace Wellman, Peace Weavers: Uniting the Salish Coast through Cross-cultural Marriages, (Pullman, Washington: Washington State University Press, 2017), 22.

162 Gilmer, 401.

163 Ibid.

164 Pascoe, What Comes Naturally, 98, 103.

165 Peterson Del Mar, "Intermarriage and Agency: A Chinookan Case Study," 15.

166 Pascoe, What Comes Naturally, 103.
} 
gross estimate. Washington Territory was not included in the Federal Census until 1860 , and at that time the population was 11,594 --seventy-three percent of which was male. By 1870 , that number grew to 23,955 , with men comprising only sixty-three percent of the population, indicating the arrival of more white women settlers in the 1860s. By 1880, the population was counted at $75,116 .{ }^{167}$ While the Native population was grossly underestimated in the census, the numbers give an accurate portrayal of territorial growth. No exact numbers are known for the years prior to 1860 , but there was a vast difference in the sex ratios of men and women, with white women being even less represented in the territory. ${ }^{168}$ This difference did not change the number of men who sought companions of the opposite sex, inevitably leading to relationships with Indigenous women. It is impossible to determine how many interracial relationships occurred during the course of Washington Territory history, but prosecution rates from the territorial court provide evidence that these pairings were far from uncommon. Of eightyfive cases concerning fornication and adultery brought to the territorial court between 1853 and 1889, thirty-seven involved interracial relationships consisting of white men and Indian women. ${ }^{169}$

The miscegenation laws enacted in Washington Territory in 1855-1868 resulted from two important factors: the arrival of white women in the region, and the start of reconstruction in the post-Civil War United States, which led to the

\footnotetext{
167 Gilmer, 398-399.

168 Ibid.

169 Gilmer, 399-400.
} 
movement towards legal equality among the races across the United States, not just in the South. The criminal bans on interracial marriage were lifted, not because of progressive and anti-racist ideology emerging, but as part of the nation's attempt towards legal equality. ${ }^{170}$ While the laws criminalizing marriage were lifted, regulation and restrictions of Natives' rights continued to be prevalent in Washington Territory. Laws enforcing white superiority reflected the true sentiments of the settlers. Territory laws dictated that Indians were not allowed to testify in civil cases in which a white person was a party, and Indians were only allowed to testify in a criminal case if they were the defendant. ${ }^{171}$ While miscegenation laws were lifted, the courts utilized other legal methods to discourage and penalize interracial families, ensuring that wealth and property remained in the hands of white descendants--protected by their relation and citizenship status--rather than racial minorities. ${ }^{172}$

While this criminalization was comparatively short-lived in Washington Territory, it occurred within the time that Kitty and August were together. No evidence suggests that August or Kitty faced any criminal penalties, or that Kautz's standing in the military could have affected the way the territorial laws applied to him. The consequences lie with their children, regarding their legitimacy and rights to inheritance after August's death. The interracial union

\footnotetext{
170 lbid., 408.

171 Ibid., 404.

172 lbid., 395-396.
} 
between August and Kitty would have lasting legal repercussions outside of their relationship.

\section{The Kautz Family}

Due to August's shortened stay in 1853 , it is likely that he and Kitty were married in 1856 after he returned to replace Lieutenant Slaughter. Not all of August's journals were saved and there is no personal account of when he met Kitty or even the birth of his first son. ${ }^{173}$ It is certain that they were married, at the latest, between January 1856 and June 1856. August and Kitty's first child, Nugen Kautz, was born on March 17, 1857; they had to have been together by the late spring of 1856 in order to conceive. ${ }^{174}$

August's journal entries mostly interject on the daily workings of the fort, the men, and other military matters. Its pages reveal only highlights of his relationship with Kitty and his sons. He refers to her as "his friend," or Kate, but evidence of his true feelings are mixed. His writings suggest that he did care for the well-being of his "friend" and their children, but he often inflicted physical violence upon Kitty.

\footnotetext{
${ }^{173}$ August mentions in his journal that some of his belongings were lost when travelling from Fort Chehalis back to Fort Steilacoom in May 1861. His journal reflects that the lost trunk was mostly filled with books. Some records of his time in Washington State during 1853 exist, none of these mentioned Kitty. However, some gaps are missing from the Puget Sound Indian War. Therefore, it is likely those journals were lost and the reason why there is not a complete account of his journals from his stay in the Pacific Northwest.

${ }^{174}$ Lockley, "Biography - Kautz, Nugen," Oregon Historical Society. August named his son Nugen for one of his closest friends and classmates from West Point, John Nugen, who died October 22, 1857 of consumption, see: Lawrence Kautz, Biography of a Civil War General, 37 \& 51 for more information on John Nugen.
} 
Figure 1. Timeline: August and Kitty Kautz \& the Pacific Northwest, $1846-1868$

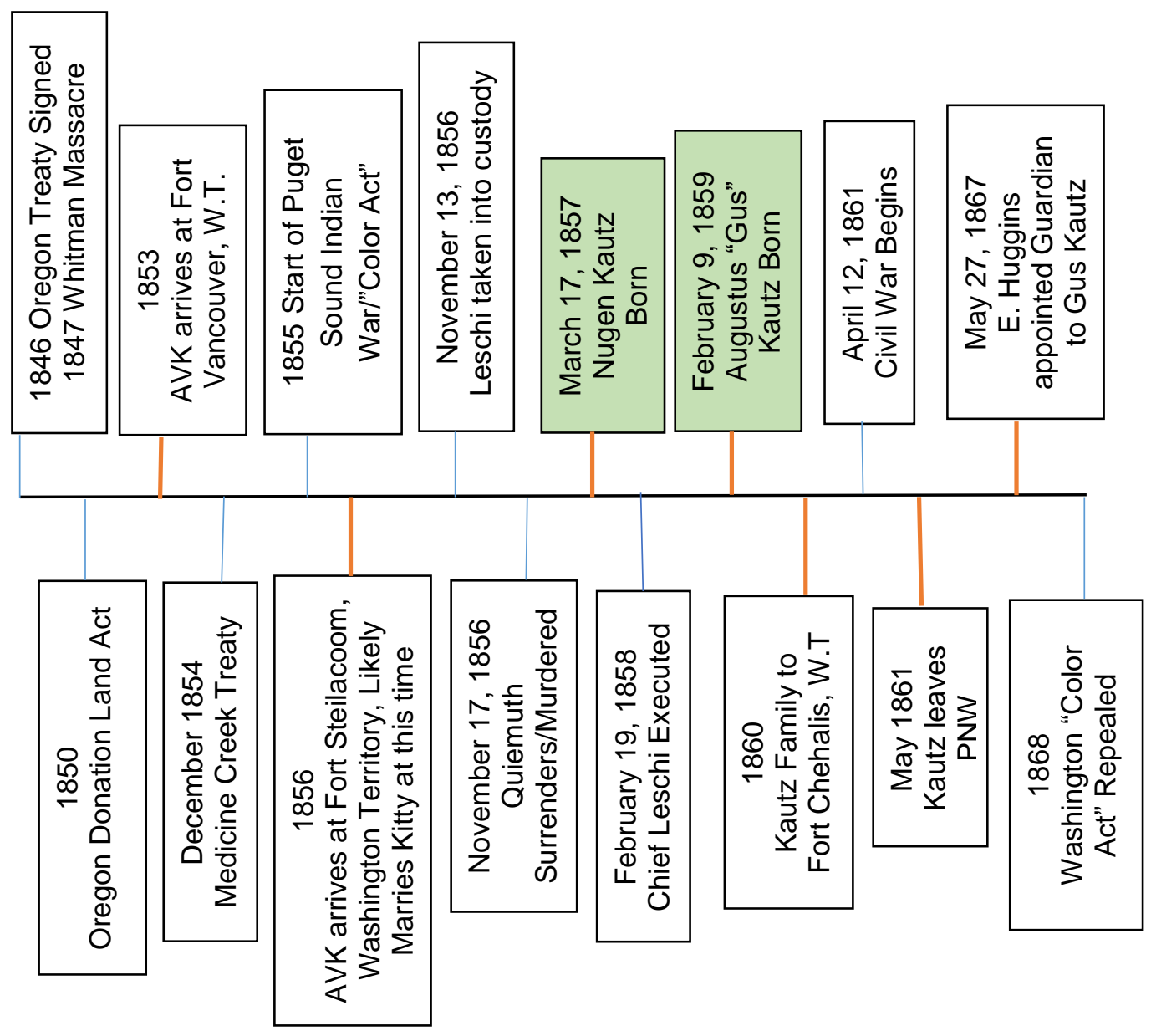

August shows concern in regard to his family's health and living conditions, he also expected obedience and subservience from Kitty. "...I had a row with my friend but nothing serious, simply a little impudence repaid by a slap; and I went off depending more on a system of coldness to produce subordination than force." 175 Though his journal entries do not suggest constant fighting, it was

${ }^{175}$ A.V.K. Journal, June 1, 1857 
present throughout their relationship. A few years later, he wrote of another altercation. "Spent the day in garrison, nothing occurred except a small domestic row in which I came out winner." 176 This type of interpersonal violence is defined by Historian David Peterson Del Mar as an attempt by one or both participants to exercise power. Peterson Del Mar defines power as the ability to control one's life and the lives of others. ${ }^{177}$ His study examines forms of violence and how they were tolerated in different social and political environments. He highlights the general intolerance of wife-beating among Puget Sound and Northwest Coast tribes. "Abused Native wives did not simply wait for their families of origin to intervene. They acted on their own behalf. Divorce was not uncommon on the Northwest Coast, and wives often left physically abusive husbands. Wives married to such men in the interior generally enjoyed fewer options, but here, too, some groups allowed them to escape violent spouses."178

August does not document many cases of violence against Kitty, but that does not indicate the absence of other altercations. Other evidence suggests he saw her roles as subservient to him. He expected her to care for his personal space and belongings. “...K. Takes care of my room but does very indifferently..." 179

\footnotetext{
176 Ibid., March 15, 1861.

177 David Peterson Del Mar, Beaten Down: A History of Interpersonal Violence in the West, (Seattle: University of Washington Press, 2002), 7.

178 Peterson Del Mar, Beaten Down, 18. Peterson Del Mar's What Troubles I have Seen: $A$ History of Violence Against Wives, provides further analysis on violence against wives specifically. He identifies the settlement period in Oregon as one that perpetuated a culture of violence followed by a period of self-restraint in the 1890s that was intolerant of wife beating.

${ }^{179}$ A.V.K. Journal, November 19, 1857.
} 
While it is evident in his journal entries that Kautz held some degree of affection for Kitty and his sons, there is no evidence if those feelings were reciprocated by Kitty. Candace Wellman who studied Indigenous wives of white settlers specifically notes in her work that she chose not to speculate on the emotions or motivations of the women she studied, as she was "not of their time nor their culture." 180 Alternatively, Anne Hyde's "The Blue Flower and the Account Book: Writing a History of Mixed-Blood Americans" seeks to answer those questions. Hyde's understanding of the relationship between Henry and Jane Schoolcraft, a mixed-race couple who met in 1822, is dependent on understanding if they loved each other. Henry was a white sub-agent on the Ojibwe Reservation in the great lakes region; his family were farmers in New York. Jane was the daughter of an Irish immigrant fur trader and prominent Ojibwe woman. ${ }^{181}$ Love was important because it changed the way Hyde understood the actions within their own "messy, long-distance relationship complete with interfering in-laws, crazy siblings, parental challenges, and money worries," along with the cultural difference. ${ }^{182}$ Though Hyde sought to answer those questions, she acknowledges, "historical questions about identity and love are only incompletely answered by the traces people leave behind them." ${ }^{183}$ With no accounts from Kitty, speculation of her sentiments is futile. August's role as a

\footnotetext{
180 Wellman, Interwoven Lives, I, XV.

${ }^{181}$ Anne F. Hyde, "The Blue Flower and the Account Book: Writing a History of Mixed-Blood Americans," Pacific Historical Review 85, no. 1 (2016), 13. 182 Ibid., 17.

183 Ibid., 2.
} 
colonizer, especially one who often showed abusive tendencies towards Kitty, creates a power dynamic that fosters an environment of complex relationships. Love does not necessarily have a dominant role--at least not in the romanticized sense. ${ }^{184}$

Even with the consideration that Kitty and August's relationship may not have fostered real love, his actions and journal entries indicate, at minimum, a sentimental attachment to his family. His writings-show concern for his son Nugen, whom he affectionately calls Lugie when he fell ill at six months old.

[September 6, 1857]

...Lugie is quite sick. His lungs affected by the hooping cough and fear he will have a wretched time.

[September 7, 1857]

...We had quite a time administering to the little patient.

[September 14, 1857] ...Lugie is improving very much. He has almost entirely recovered from the hooping cough or at least from the inflammation of the lungs brought on by it. He has been very sick, we have kept him in the house in my bedroom for several days out of the cold air and he is almost entirely recovered...

[September 19, 1857] ...Lugie has recovered, all inflammatory symptoms have disappeared but he still has hooping cough... ${ }^{185}$

\footnotetext{
184 Trevor G. Burnard, Mastery, Tyranny, and Desire: Thomas Thistlewood and His Slaves in the Anglo-Jamaican World. (Chapel Hill: University of North Carolina Press, 2004); Slave owner Thomas Thistlewood maintained a "romantic" relationship with his slave Phibbah for years, his meticulously kept journals highlight his other sexual encounters, consensual and non-consensual, with other slaves. We do not know if Phibbah cared for Thistlewood, or if Thistlewood loved Phibbah, the relationship serves an example of whether or not romantic love, or consensual relationships, can truly exist within those power dynamics.

185 A.V.K. Journal; September 6, 1857, September 7, 1857, September 14, 1857, \& September $19,1857$.
} 
August certainly felt undeniable concern for the boy. However, it is worth noting that up until this point journal entries made no mention of his child. In 1857, his journal entries started in June, so there is no preserved record for the first three months of Nugen's life or August's account of his first born son's birth. In fact, in his almost daily journal entries August rarely mentions his "friend" or his children unless there was cause for concern. August also writes about his family in regards to their living situations. He cared enough to make sure they were comfortable and seemingly desired to keep them close.

When Nugen was sick, August notes they kept him in August's room and out of the cold air, indicating that Kitty and Nugen did not consistently room with him. A year later, evidence suggests August had both the ability and authority, to move his family into his housing. In 1858, while stationed at Fort Steilacoom, August was rooming with his friend, Dr. Wirtz, who suspected his "Indian friend" Lola of stealing. August wrote, "...the Indians have stolen thirty dollars from him and he very strongly suspects Lola. He sent her off. He was in a bad humor in the afternoon and wished me to send my dependents also away, as he did not wish to keep his doors locked all the time, as he said he would now be compelled to do."186 Dr. Wirtz, a close friend, and colleague of August's, strongly desired August to send his family away and thought his request to do so was reasonable. August had a differing opinion, writing in his journal, "The request was exceedingly unreasonable and I gave him no answer. I have no intention of

${ }^{186}$ Ibid., August 5, 1858. 
complying with his request." ${ }^{187}$ August's response indicates that he did not want to part with his wife and son.

Based on the journal entry, Kitty and Nugen were rooming with August for at least a portion of his stay at Fort Steilacoom. It is hard to say how long that lasted, as an entry four months later indicated they were no longer living together. In a journal entry dated December 15, 1858, August states, "I started for Olympia in the afternoon and rode as far as the reservation where I concluded to stop all night. I found Etta and Lugie very well and comfortably situated." 188 His journal entries, while dominated by military matters and daily life on the post, is speckled with notes on the well-being of his family. In the same entry, August comments, "The Indians here are becoming civilized very rapidly. Some of them live like ordinary white people of the country in log cabins with floors, chairs, tables, bedsteads, \&c. It is a degree of improvement that surprises me not a little in the present condition of Indians who a few years ago were as wild as any savage." 189 This entry reflects the common sentiments of settlers and perpetuates the American assumption that their presence had a civilizing influence on the Native tribes.

When Kitty gave birth to their second child, August once again noted his concern for both mother and son.

187 Ibid., August 5, 1858.

188 Ibid., December 15, 1858.

189 Ibid., December 15, 1858. 
[February 9, 1859]

...A brother to Lugie arrived in this world today about three o'clock p.m. The mother was out in labor more than an hour. I called in an old Lummi but her practice of midwifery did not suit Kate and I brought in Dr. Berrien and in a short time after his arrival the boy was born, who I shall call Doctin, in consideration of my numerous friends of the medical profession. The mother is doing well. ${ }^{190}$

August's report on the birth of his second son shows he is interested in the health of both mother and child, and has the means of offering Kitty a Lummi midwife and a doctor. Kitty's preference for a doctor instead of a midwife strays from the practice of Indigenous birthing traditions. According to Nisqually tribal historian Cecilia Svinth Carpenter, Nisqually women would set up a secluded shelter away from the village assisted by a midwife. ${ }^{191}$ After birth, the women were confined for a period of five to fifteen days, during which the men were not allowed near their wives. ${ }^{192}$ Kitty chose a medically trained doctor over a traditional midwife, and her relationship with August gave her access to both options. August further reflected on Kitty's delivery and postpartum recovery: "She is much better than a white woman would be under the most favorable circumstances, nature is a better mother than not." August was not alone in praising Native women's birthing practices. ${ }^{193}$ Colonel Phillipe Trobriand, a male officer in the military, also suggested that Native women's natural way of birth

\footnotetext{
190 lbid., February 9, 1859. At his birth, Kautz gave his second son the name Doctin, later in life he would be known as Augustus or Gus.

${ }^{191}$ Carpenter, The Nisqually--My People, 96.

192 Haeberlin, 43.

${ }^{193}$ Sherry L. Smith, The View from Officers' Row: Army Perceptions of Western Indians, (Tucson: University of Arizona Press, 1990), 64; Meeker, 221.
} 
was superior to white women's, who he believed had been corrupted by society's insistence on intervening with bed rest, doctors and medicine, for such a "natural" and "easy" process as childbirth. ${ }^{194}$ Later in his journal, Kautz indicated that Kitty's postpartum recovery was not as smooth as they had thought. It seems that while childbirth is often unpredictable and rarely easy, men's opinions on women's bodies remain consistent. To his credit, August's concern for Kitty is evidence of the affection that is missing from so much of his journal.

[February 11, 1859] ...Etta was quite unwell. She has not got through her labor so comfortably as we were led to expect. I spent the greater part of today loafing...

[February 12, 1859]

...Etta is quite sick yet. She doesn't improve much...

[February 14, 1859]

...K is improving very slowly...

[February 17, 1859]

...K. is quite well again... ${ }^{195}$

Though August focused mostly on documenting his and his families' ailments and injuries, his journal entries also convey an interest in ensuring his sons would be educated "...I had a long talk with B. last night about the dependants. He laughs about my propositions to have the little ones brought up as Boston children and ridicules the idea of them turning out like others..."196

194 Smith, The View from Officers Row, 64.

195 A.V.K. Journal; February 11, 1859, February 12, 1859, February 14, 1859, \& February 17, 1859.

196 Ibid., February 22, 1859. The term "Boston" was used in reference to American Settlers. 
August wanted his sons to have access to opportunities that would facilitate their success as adults.

In 1859, August received permission to go to Ohio to visit family and then travel abroad. He left Kitty to care for Nugen and the two-month-old Doctin. Prior to leaving, he arranged for their care and financial security.

[April 23, 1859]

I stopped at Dr. Tolmies and made arrangements with him for taking care of my little family. I left a hundred dollars with him and shall send him ten more. They are to have a cow and the balance of the money is to be paid to them periodically. ${ }^{197}$

August also noted that his friend, Mr. Gosnell, had volunteered to look after his "Indian friends." August expressed his appreciation for Gosnell's character and that he was "down on Indian killing." 198 Despite his arrangements with Tolmie, his family's comfort and safety remained on his mind while he was away. "I bid goodbye to my Indian friends on the reservation. Rode to Dr. Tolmies where I made some additional arrangements with $\mathrm{Dr}$. T. about my little ones." 199 An entry dated March 27 indicates that August was packing his belongings in preparation to leave his family. "Spent the day packing up. It hailed, rained and snowed today nearly all day more or less. I am preparing to leave on the next trip of the Constitution. Etta gave some information about her father's family that I think worth recording." He mentions the information related to Kitty's father but does not mention him by name. According to his journal, only a couple of their

\footnotetext{
197 Ibid., April 23, 1859.

198 Ibid., April 23, 1859.

199 Ibid., April 24, 1859.
} 
relatives were still living at the time--Lugie's great grandfather on his grandmother's side, Yak-tah-quat, and an unnamed grandmother. ${ }^{200}$ As August was getting ready to leave his wife and children, he thought it important to document the history of the family to which he now belonged through his two young sons and Kitty.

August returned to Ohio, where he visited his family, and then traveled to Europe. When he returned to the Pacific Northwest, Kautz was assigned to Fort Chehalis, Washington Territory. ${ }^{201}$ He made his way back to Fort Steilacoom and the Nisqually Reservation to retrieve his family before they headed to his new post. He visited his family shortly after his arrival, "...I went by the reservation and stopped an hour. They were glad to see me and seemed in the most perfect health. I find that they have conducted themselves very well and remained on the reservation since I went away." 202 On October 29, 1860, he wrote, "I spent the morning in garrison and in the afternoon rode out to the reservation." On November 8,1860 , he visited his family again "...I stopped for the night at the reservation." 203 He made regular visits before the family went to Fort Chehalis together.

200 Ibid., March 27, 1859. The journal entry also highlights other members related to Kitty, and their sons Lugie and Gus. "Pugnillton was a younger brother of Etta's grandfather, Coqiltouns father whose name was Lai-a-wak was a great chief and traveller. He made excursions far to the eastward for buffalo. Coquiltoun had a sister who was Allen's grandmother on his mother's side." 201 Unpublished draft of Autobiography, Box 8, August V. Kautz Papers, Manuscript Division, Library of Congress, Washington, D.C.

202 A.V.K. Journal, October 25, 1860.

203 Ibid., October 29, 1860, November 8, 1860. 
August remained with his family throughout his stay at Fort Chehalis. His journals reflect the daily happenings at the post and his lack of concern for the looming sectional conflict. ${ }^{204}$ In his usual fashion, he comments on his family's health and well-being, noting accidents and general wellness in his journals. When he references Kitty, he offers few details or sympathy. "K. is very unwell and has been complaining for several days." ${ }^{205}$ His entries regarding his sons tend to be more descriptive and sympathetic on his part, though the nature of their injuries may have warranted deeper concern.

[March 11, 1861]

Spent the day in quarters. Nothing occurred worthy of note. Lugie has been in bed all day. He fell on his abdomen and cut a wound just below the navel with a broken bottle that gave us much alarm when he was first brought in by a soldier bleeding profusely. The wound proved light but still a narrow escape...

[March 26, 1861]

An exceedingly painful accident occurred to Doctin this morning. He ran against a bucket of hot water which his mother was carrying and severely seared his face, breast and right arm. The Doctor came to his relief immediately covered the wounds with sweet oil and lint and afterwards prepared a compound of sweet oil and lime water which seems to relieve him very much.

[March 27, 1861]

This day was spent in quarters. Doctin bears up with his misfortune exceedingly well and will recover without anything worse than a marked face...206

\footnotetext{
${ }^{204}$ August's journal entries noted the news of potential war; he did not take the news seriously at first. However, it soon became evident that he would be called away from the Pacific Northwest. 205 Ibid., February 15th 1861.

206 Ibid., March 11, 1861, March 26, 1861, \& March 27, 1861.
} 
During his second stay with his family in Fort Chehalis, August mentions Kitty and the boys more frequently. His entries typically involve accidents, and while his concern for his family is clear, he notably does not document any moments of joy in his family's life; there are no happy moments or memories recorded. As the Civil War loomed, Kautz prepared for his orders of departure, which came in 1861. He packed his belongings and began the process of returning his family to the Nisqually Reservation near Fort Steilacoom, before his own return to Ohio.

Kitty and August departed Fort Chehalis separately on May 21, 1861; "I sent my baggage and Mary Gerlach and Kate in a wagon to Steilacoom and I took the steamer." 207 In the days leading to his final departure, August visited the reservation to see his family several times. On May 30,1861 , he wrote, “...I stopped an hour or two at Olympia to rest and then rode to the Nesqually reservation. Etta was absent..." On May 31, 1861, he reflected in his journal, “...Etta arrived with her children and camped at Simakins Camp beyond steilacoom creek not far from Birds mill." ${ }^{208} \mathrm{He}$ visited again on June 1, 1861, "Rode to Fort Nesqually and have a very pleasant time visiting the people there. Returned in time for dinner. Steinberger and I went out to Simakins Camp in the evening after supper."209 While his visits were frequent, his language changed.

\footnotetext{
207 Ibid., May 21, 1861.

208 Ibid., May 31 1861. Simakins Camp is mentioned in the BIA report as an Indian Camp near Fort Steilacoom. United States Department of the Interior, "Summary Under the Criteria and Evidence for Proposed Finding Steilacoom Tribe of Indians," 67.

209 A.V.K. Journal, June 1, 1861.
} 
He mentions Kitty arriving with her children--not his sons, or his children, or their children, but her children. It seems he was attempting to distance himself from them, despite his frequent visits leading up to his departure.

When Kautz left the region to fight for the Union during the Civil War, he made arrangements for the care of the boys--arrangements that, markedly, did not provide for Kitty to be their primary caregiver. He entrusted his friend Edward Huggins to make decisions for the physical and financial well-being of his sons. "He made arrangements with me to act as his agent, and I paid this woman a monthly allowance, to be spent upon the children."210 Kitty seemingly still maintained custody of her sons--that is until Huggins found homes for them "in the families of decent Americans."211 Until his departure August had provided financial support but allowed Kitty to keep the boys in her custody; when he was leaving permanently, he made arrangements that removed their sons from her care.

It can never be truly known whether Kitty was deprived of her maternal rights, or if she willingly gave them up. The removal of Indigenous children-under the guise of the religious superiority of missionaries, reformers and government agencies--was a tactic of settler colonialism used in the United States and elsewhere to disrupt Indigenous communities that threatened nationbuilding efforts. ${ }^{212}$ The Pacific Northwest has a long history of depriving Native

\footnotetext{
${ }^{210}$ Huggins, "Biography - Kautz, A.V," Oregon Historical Society.

211 lbid.

212 Margaret Jacobs', White Mother to A Dark Race, parallels the Indigenous child removal in both the United States and Australia as consequence of Settler Colonialism.
} 
women of their maternal rights. Historian Katrina Jagodinsky's Legal Codes and Talking Trees: Indigenous Women's Sovereignty in the Sonoran and Puget Sound Borderlands, $1854-1946$ presents six case studies analyzing the ways in which territorial courts asserted their control, and how women fought back. Jagodinsky emphasizes the role of the probate court in relocating Indigenous women's children outside their care. This typically happened when Native women's white, male partners died or left. ${ }^{213}$ The common placement of Indigenous children was with white, male guardians. ${ }^{214}$ Jagondinsky's analysis of one Native child, Nora Jewell, exemplifies this pattern. T.W. Bogness, a widower, was first appointed as Nora's guardian after her father's death--despite an aunt and uncle of the girl living nearby. ${ }^{215}$ Without explanation, the probate records indicate a shift in Nora's guardianship, this time to the household of James F. Smith, where she faced "domestic, field, and sexual servitude."216

Kitty and August's interracial union may have been considered legal at some point; however, it did not grant Kitty any legal rights to her children. Probate records from Washington Territory show that Gus' guardianship was transferred from Edward Huggins to Warren Grove; materials from the court records dated 1871 include letters to the court and other documents detailing the change. The records reflect that Huggins was appointed as guardian of Gus by

\footnotetext{
${ }^{213}$ Wellman, Peace Weavers, 45.

214 lbid.

${ }^{215}$ Katrina Jagodinsky, Legal Codes and Talking Trees: Indigenous Women's Sovereignty in the Sonoran and Puget Sound Borderlands, 1854-1946, Lamar Series in Western History. (New Haven: Yale University Press, 2016), 70.

216 Ibid., $72-74$.
} 
the probate court on May 27, 1867, when Gus was 8 years of age. Four years later, on August 4, 1871, Huggins petitioned to the court. Huggins stated that he wished to be released from guardianship of Gus and 'that he is now, and has been for a long period of time, residing with, and under the care of Mr. Warren Gove of Steilacoom, who took charge of him at my request also at the particular request of the boys father, a now resident of Ohio Territory."217 Included is another letter from Warren Gove requesting to be appointed the guardian of Gus Kautz. ${ }^{218}$ Kitty was not mentioned or acknowledged at any point in the probate records on guardianship of her son. This absence and lack of acknowledgment may indicate that Kitty welcomed the opportunity for her sons to be placed in homes that would give them access to education. Kitty's maternal rights were not directly denied by the Washington State Courts; Neither Tenas, nor Kitty, nor Kate is ever mentioned in the probate records. We have no record of Kitty's opinion or feelings regarding the placement of her sons outside of her care. While we cannot assume she was outright deprived of her rights, we also cannot assume that she freely and willingly let her sons be raised outside her care.

The probate records on young Gus Kautz reveal the boys were not raised in one home throughout their lives. We know Huggins placed them in two separate homes, and evidence shows those homes changed. Nugen Kautz was originally placed in the home of W.B. Gosnell at Cowlitz Landing. ${ }^{219}$ Gosnell was

217 Guardianship Case 1867, Augustus Kautz, Pierce County, County Clerk, Probate Case Files, Puget Sound Branch, Washington State Archives.

218 lbid.

219 Lockley, "Biography - Kautz, Nugen," Oregon Historical Society. 
a friend of August's during his appointment at Fort Steilacoom and he previously looked after August's family. August had commended him for being "down on Indian killing."220 Nugen was with Gosnell from the time he was seven until he was sixteen. While housed there Nugen "...milked the cows and fed the pigs and did the work of a man."221 When Kitty visited Nugen, he told her he wanted to receive an education, and that he was not with Gosnell. In an interview, Nugen told Fred Lockley, "When I told her how anxious I was for an education she sent word to my father and he wrote to Edward Huggins and had me taken away from Mr. Gosnell and put in charge of Captain Warren Gove, where my brother was. Captain Gove moved to Steilacoom. I stayed with him 15 months. During that time I had 12 months of schooling." During the nine years that Gosnell served as his guardian, Nugen attended school for a mere nine months. ${ }^{222}$ Jagodinsky identifies the result of Washington's Territorial guardianship practices as a means for pioneering men to exploit child labor, exemplified in both Nora Jewell's and Nugen Kautz's stories. ${ }^{223}$ Nugen had advocates in his mother, father, and Edward Huggins who petitioned for his change in guardianship. While Kitty did not have custody of her children, Nugen's interview suggests that she remained in contact with her sons and had a certain amount of influence--through Kautz and Huggins--to ensure her sons received the education they wanted. Using the

\footnotetext{
${ }^{220}$ A.V.K. Journal, April 23, 1859.

${ }^{221}$ Lockley, "Biography - Kautz, Nugen," Oregon Historical Society.

222 Ibid.

${ }^{223}$ Katrina Jagodinsky, "'In Family Way": Guarding Indigenous Women's Children in Washington Territory," American Indian Quarterly 37, no. 1-2 (2013), 163.
} 
resources available to her, she demonstrated her ability to navigate her changing world.

We know the outline of Kitty's life, but we cannot know the choices she faced or how much control she had over the decisions that directed the course of her life. An examination of other Native women's choices indicates that Kitty's options and opportunities were not completely limited. Historian David Peterson Del Mar argues that Native women could use the newcomers to their own advantages; his analysis of Celiast Smith, a Chinook woman born at the mouth of the Columbia River in the nineteenth century, offers a parallel to Kitty's life and choices. Unlike Kitty's, Celiast's life was unusually well documented. Her first marriage to French-Canadian Basile Poirier, gave her wealth, a degree of status, and property--all while she remained among her people. ${ }^{224}$ Later in her life, she asserted her own power to obtain a divorce and trade an unsatisfying marriage for one that better suited her needs. ${ }^{225}$

Kitty's choice in a partner may have been partly directed by emotional connection, but it could also be the result of her will to survive. An officer in the United States military provided a degree of protection, security, and resources. While August's journals reveal some sense of care and moral responsibility, scant little sign of true devotion or even affection can be found in his writings, and

\footnotetext{
${ }^{224}$ Peterson Del Mar, "Intermarriage and agency: A Chinookan Case Study," 8.

225 Ibid., 21-22. Peterson Del Mar's case study highlights the ways in which Celiast Smith used marriage to her advantage to gain independence, and some wealth. Her life illustrates the diverse and complicated ways in which Native Women responded to colonization amidst all of the "disease, death, violence, and cultural dislocation" for other Chinookan women.
} 
he often resorted to physical violence to exercise his authority over Kitty. Perhaps it was a relationship forged out of mutual self-interest for both parties. Particularly amidst the uncertainty and changing social structures of Washington Territory, American military officers promised access to goods and greater protection for an Indian woman and her family. August's subsequent marriages would deviate from his relationship with Kitty. The ways in which he acknowledged, treated, and wrote about his other wives, Charlotte and Fannie, further illuminate his relationship with Kitty, and this analysis would not be complete without telling their story. 


\section{Chapter Two \\ “My Poor Silly Wife”: Fannie Markbreit Kautz, 1872-1892}

\section{Fort Garland, Colorado - 1873}

The baby cooed softly, nestled warmly in his mother's arms, as the train pulled up to the station. The mother, holding the baby tightly in her arms exited the train, the father following close behind as they stepped into the brisk Colorado air. The family took in the landscape of their new home; snowcapped mountains and open space. It had taken five large wagons to transport the family and all their possessions, including their piano and all of the furniture for their new home. Arriving safely at Fort Garland in November 1873, just eight days after leaving by train from Ohio. A journey that would have been a strenuous, months-long, ordeal a few years earlier was now made relatively safe and much faster thanks to the completion of rail lines. A journey that would undoubtedly have placed the couple's two-month-old child, and their piano, at great risk. Instead, the family was able to bring all the comforts of home and their health from back east as they started their lives in Colorado.

Fannie Markbreit, the third wife of August Kautz, was born on June 24, 1848, in Baden, Germany to Leopold and Johanna Markbreit. ${ }^{226}$ Fannie met August while she was staying with mutual friends, the Conrad's, in 1872.227 August, then in command of Newport Barracks, was acquainted with Lieutenant Conrad, with whom he had been stationed in New Mexico. Mrs. Conrad remained in Cincinnati, Ohio while her husband was stationed out west. While in Cincinnati, Mrs. Conrad cultivated a vast social circle, which she brought with her to Newport Barracks--including the young Fannie Markbreit. ${ }^{228}$ August and Fannie's courtship began with August's arrival at Newport Barracks in 1872, a decade after August left his family in the Pacific Northwest. The years that had

${ }^{226}$ Fannie Markbreit Kautz, grave marker, Arlington Cemetery, Virginia, United States of America, digital image at Findagrave.com, (Accessed July 2, 2019).

${ }^{227}$ A.V.K Journal, June 2, 1872.

${ }^{228}$ Kautz, Biography of a Civil War General, 194. 
passed were filled with sectional conflict and personal loss that shaped August's life before he met Fannie.

\section{Civil War \& New Orleans, Louisiana: 1862 - 1868}

After Colonel August Kautz arrived in Ohio to fight in the Civil War, he received an invitation to dinner at Governor David Tod's home on December 19, 1862. He noted in his journal that day, "the daughters are pleasant enough, one of them is pretty." 229 He was referring to Charlotte Tod, who by 1865 would be called Mrs. Kautz. August proposed marriage on April 5, 1863. His wartime duties meant their courtship played out in letters and postponed their wedding several times. ${ }^{230}$ Charlotte refused to be married unless they could live together. August knew that would be impossible if he were called to the field, orders he eventually received in $1864 .{ }^{231}$

A day after General Lee's surrender on April 9, 1865, August began the process of returning to Charlotte. ${ }^{232}$ On April 12, he wrote to General Grant and requested permission to return to Ohio for his wedding. ${ }^{233}$ Further news on April 16,1865 , would disrupt his plans: "Mr. Lincoln is not expected to live, I was very much shocked by this intelligence." ${ }^{234}$ Kautz was referring to the tragic news that President Lincoln was shot; he did not recover from his wounds, and Kautz's military duties were not yet over.

\footnotetext{
${ }^{229}$ A.V.K. Journal, December 19, 1862.

${ }^{230}$ Kautz, Biography of a Civil War General, 173.

231 Ibid.

${ }^{232}$ A.V.K. Journal, April 10, 1865.

233 Ibid., April 12, 1865.

234 Ibid., April 16, 1865.
} 
Kautz reported to General Grant in Washington D.C. on May 6 and was given the opportunity to serve on the commission to try the Lincoln Conspirators. Grant gave Kautz the choice to serve on the commission or continue with his leave. Kautz noted in his journal that he wrote a letter to Miss C., the contents no doubt explaining his choice to postpone their wedding yet again as his sense of duty overcame his matrimonial desires. ${ }^{235}$ The military commission was established following the assassination of President Lincoln, the attempted assassination of Secretary of State William Seward, and the plot to murder Vice President Andrew Johnson by, John Wilkes Booth, Lewis Thornton Powell, and George A. Atzerodt. The investigation found a total of seven men, and one woman, involved in the conspiracy and they were all subsequently put on trial. ${ }^{236}$ The conspirators were tried by a military commission instead of in civilian court because their crimes were deemed acts of war. ${ }^{237}$ Kautz was joined by several other members of the Union Army: Brigadier General Thomas M. Harris, Brigadier General Albion Howe, Brigadier General Robert S. Foster, and Major General Lew Wallace. ${ }^{238}$ The trial lasted fifty days; sentencing was passed on July 6, 1865. Four were sentenced to death, including Mary Surratt, the first woman in history to be sentenced to death by the United States Government. Three were sentenced to life in prison, and the last conspirator was tried by a

\footnotetext{
235 Ibid., May 6, 1865.

${ }^{236}$ Fred L. Borch, "'Let the Stain of Innocent Blood Be Removed from the Land": The Trial of the Lincoln Assassination Conspirators by Military Commission," Army History, no. 86 (2013), 7. ${ }^{237}$ Ibid., 12.

238 Ibid., 14.
} 
civilian court, which resulted in a hung jury and mistrial. ${ }^{239}$ Kautz remained relatively quiet on his thoughts during the trial in his journal, but he was one of five members of the commission to sign a letter to the President recommending a lighter sentence for Mary Surratt. ${ }^{240}$

After the trial of the Lincoln Conspirators, August made his way back to Ohio, uncertain of where his relationship with Miss Tod stood. Any latent issues the couple might have had were laid to rest and August married Charlotte Tod on September 14, 1865. The wedding occurred "without any mishaps" and the "gentleman indulged freely of the wine in honor of the occasion," before August and his "dear wife" set off to Niagara Falls. ${ }^{241}$ After their wedding, August received orders to New Orleans. Despite Charlotte's reluctance to live so far from her family, the newlyweds arrived in New Orleans on March 1, 1866, where they checked into the St. Charles Hotel. ${ }^{242}$ Charlotte, experiencing great homesickness, would escape the hot, miserable, summers of New Orleans and visit her family in Ohio; leaving Kautz to keep company with the other officers who were made "grass widowers." 243

August's second marriage was struck with tragedy on April 14, 1868.

August wrote, "Charlotte since yesterday has been quite disturbed and sick with

\footnotetext{
239 Ibid., 17.

240 Kautz, Biography of a Civil War General, 172.

241 A.V.K. Journal, September 14, 1865.

242 Ibid., March 1, 1866.

${ }^{243}$ Kautz, Biography of a Civil War General, 176. Grass widowers refer to the men whose wives left them during the summers.
} 
loss of appetite." ${ }^{44}$ April 20 brought some improvement, "Charlotte slept well last night" and was well enough to write a letter to her father. ${ }^{245}$ His daily journal entries were a back and forth of Charlotte's symptoms improving and worsening, and the doctors' inability to cure her. On June 1, August wrote, "Charlottes condition was alarming this morning," and sent a telegram to Charlotte's family stating that they should come immediately. ${ }^{246}$ By June 3, Charlotte had succumbed to typhoid fever. ${ }^{247}$ He spent the initial days following her death with his in-laws and family. He started writing in his journal again on June 8; August did not mention Charlotte until June 12, 1868. "I saw that she was dying. I called up Dr. Price \& he called Dr. Mayer. They both came and pronounced her sinking fast. She was entirely unconscious. I watched by her bed side for a last gleam of light until eight o'clock when she breathed her last, June 3rd, 1868." ${ }^{248}$ Charlotte died after just three years of marriage and almost six years after meeting August. His melancholy lifted enough to think about the future on June 12,1868 , he wrote, "I must get something to do that will occupy my mind and prevent me from dwelling on the loss I have sustained."249 August visited old friends and traveled to Mexico City to explore the region and fill his loneliness. ${ }^{250} \mathrm{He}$ was then stationed for three and a half months at Fort Craig, New Mexico, a temporary

\footnotetext{
${ }^{244}$ A.V.K. Journal, April 14, 1868.

245 Ibid., April 20, 1868.

246 Ibid., June 1, 1868.

${ }^{247}$ Kautz, Biography of a Civil War General, 181.

248 A.V.K. Journal, June 12, 1868.

249 Ibid., June 12, 1868.

250 Kautz, Biography of a Civil War General, 182-183.
} 
assignment before his permanent post on October 12, 1869, to Fort Stanton, New Mexico. 251

\section{Fort Stanton, New Mexico Territory: 1869 - 1872}

New Mexico Territory encompassed a vast expanse of land that makes up what is now New Mexico and Arizona. Along with the difficult geography, the region was composed of Spanish, Mexican, Indian, and Anglo cultures that created unique problems as the United States attempted to separate the Indian tribes from the incoming settlers and protect the proposed railroad lines. ${ }^{252}$ The Ute, Navajos, and Apache tribes of the Southwest were uprooted from their homelands to satisfy American ideals of Manifest Destiny. ${ }^{253}$

Incoming settlers often referred to the Mescalero Apache bands by different names relating to geographic markers in their occupied territories. According to oral history handed down through generations, the Apache people inhabited the region from the beginning of Apache memory, their homelands covering present-day New Mexico and south into Chihuahua, Mexico. ${ }^{254}$ The 1848 Treaty of Guadalupe Hidalgo between Spain and the United States placed the Mescalero Apache in United States territory. ${ }^{255}$ Few settlers traveled through the southwest until the onset of the California Gold Rush, when increased

\footnotetext{
251 Ibid., 185.

252 Robert Wooster, "'A Difficult and Forlorn Country": The Military Looks at the American Southwest, 1850-1890," Arizona and the West 28, no. 4 (1986), 340, 342.

253 lbid., 342

${ }^{254}$ Mary M. Serna, and James W. Steely. "Mescalero Apache People," http://newmexicohistory.org/people/mescalero-apache-people, (Accessed May 21, 2019).

${ }^{255}$ Serna, "Mescalero Apache People."
} 
settlers infringed upon the homelands of the Indigenous population. ${ }^{256}$ As the settlement grew throughout the 1850 s and 1860 s, violence increased as Indigenous tribes sought to protect their homelands and save their families from starvation. Responding to the rise in violence, the United States established military posts throughout the Southwest. Soldiers tried to avoid assignments in the southwest when they were able, as it was a desolate and dry place. ${ }^{257}$ Many military leaders and politicians thought the lands in New Mexico and Arizona were "unsuitable for white settlement."258

In an attempt to end violence in the region, representatives from the U.S. government met with bands of the Mescalero Apache in July 1851 . The resulting treaty promised "perpetual peace and amity," but like many treaties, Congress would not ratify it. ${ }^{259}$ Two years later, on July 1,1853 , the U.S. government signed its first treaty with the Mescalero Apache, and a reservation was established alongside Fort Stanton. ${ }^{260}$ Prior to the treaty, the Mescalero Apache relied on their ability to travel across large expanses of land for their subsistence; hunting and gathering provided the resources necessary for their survival. ${ }^{261}$ Mescalero Apache existence depended on mobility, and confinement to a

\footnotetext{
${ }^{256}$ Daniel J. Herman, Rim Country Exodus: A Story of Conquest, Renewal, and Race in the Making, (Tucson, Arizona: University of Arizona Press, 2012), 41.

257 Wooster, 344.

258 Wooster, 345.

${ }^{259}$ Serna, "Mescalero Apache People."

260 lbid.,

${ }^{261}$ Harry W. Basehart, "Mescalero Apache Band Organization and Leadership," Southwestern Journal of Anthropology 26, no.1 (1970), 88.
} 
reservation led to starvation. The Apache were unable to sustain on the meager rations of corn and beef distributed on the reservation. ${ }^{262}$

At Fort Stanton, Kautz found the daily tasks monotonous, though his time there was far from uneventful. ${ }^{263}$ In November 1869, a mere month after his arrival, a local rancher named Robert Casey accused Indians of stealing one hundred and fifteen head of cattle. Kautz ordered Lieutenant Cushing and his company to pursue the suspected thieves. ${ }^{264}$ Two weeks later, on November 23, 1869, Kautz recorded in his journal that Cushing returned with the cattle, claiming to have followed a Mescalero Apache band into the Guadalupe Mountains.

Despite being outnumbered, they killed many Indians, while only one soldier was injured. ${ }^{265}$ After Cushing's return, Kautz's journal returned to mundane reports. He wrote of studying Spanish regularly, made notes on the daily happenings of the fort, mentioned when the mail arrived, and documented his games of billiards with fellow officers. ${ }^{266}$ In December, Lieutenant Cushing, his soldiers, and a group of volunteers set out again to locate the Mescaleros in the Guadalupe Mountains and return them to the reservation. Cushing and his men found an encampment on December 26 and subsequently killed a number of the Mescaleros, with survivors fleeing as the soldiers burned the lodges, clothing, weapons, and food. ${ }^{267}$ Cushing would go on to find and destroy another

\footnotetext{
262 Ibid., 89.

${ }^{263}$ Kautz commented several times in his journal of 1869 about the dull monotony of the post.

${ }^{264}$ Kautz, Biography of a Civil War General, 186.

265 A.V.K. Journal, November 23, 1869.

${ }^{266}$ Ibid., November - December 1869.

${ }^{267}$ Kautz, Biography of a Civil War General, 187.
} 
encampment before returning to Fort Stanton. Kautz recommended Cushing for promotion for his deeds. ${ }^{268}$

In February 1870 , some Mescalero Indians slowly started to return to the reservation near Fort Stanton, faced with starvation both on and off the reservation. Throughout the year, the army marched through the Guadalupe Mountains, scouting for Indians who had not returned to the reservation. They were mostly unsuccessful until November 1870 , when they captured a small group consisting of three women, one of whom was the wife of Jose la Paz, a minor chief of the Mescaleros. ${ }^{269}$ On November 22 Kautz wrote, "I also had a talk with the Indian squaw who is a prisoner here and have arranged to send her out tomorrow to see if she can bring in some of her tribe." 270 Kautz allowed her to return to her people so that she might convince them to come back to the reservation; she reported that they were starving and had little supplies, as they had not yet recovered from the violence inflicted by Lieutenant Cushing and his men over the course of the previous year. Slowly, the members of the Mescalero tribe returned to Fort Stanton. ${ }^{271}$ Kautz brokered a halt in direct violence by sending the captive wife of Jose la Paz out to return her people to the reservation. That peace would be short-lived, however; the Mescalero Apache

\footnotetext{
268 Ibid.

269 Ibid.

${ }^{270}$ A.V.K. Journal, November 22, 1870. "Squaw" is a derogatory term, used in this context to reflect the sentiments of the time, not to condone the use of the term.

${ }^{271}$ Kautz, Biography of a Civil War General, 187.
} 
would continue to face violence and destruction at the hands of the United States Army.

In 1870, while Cushing was scouring the southwest for Indians, August briefly returned home to spend time with friends and family. Two years had passed since he lost his beloved wife, and though August missed her immensely, he desired a new romantic partnership. While in Ohio, he reconnected with Charlotte's family and developed strong feelings for her sister, Grace Tod. ${ }^{272}$ After dwelling on how to react to these feelings, August decided to propose marriage in a letter. Grace Tod's response dated October 3, 1870, expressed her surprise at his proposal; "I do not reciprocate your feelings at all, always have respected you, and liked you more for my sister's sake than anything else, and besides there is such a disparity in our ages." 273 Grace Tod had no interest in protecting August's emotions in her rejection, "I think it would have been better if you had never mentioned the subject, for you might have known by my actions that I never suspected how you felt, and did not entertain anything but sisterly affection for you. Hoping you may recover from this fancy, for I can think it nothing else."274 August returned to New Mexico without a prospective wife--“It is a cold and unfeeling rejection and will aid me greatly in overcoming this unhappy passion."275 In 1872, Kautz received orders to Newport Barracks. He took

\footnotetext{
272 Ibid., 188.

273 Grace Tod Letter to August V. Kautz, October 3, 1870, Box 7, August V. Kautz Papers, Manuscript Division, Library of Congress, Washington, D.C.

274 Ibid.,

${ }^{275}$ A.V.K. Journal, October 7, 1870.
} 
command in May and took the time to visit with the Tod family in July. ${ }^{276} \mathrm{He}$ noted that his feelings for Grace Tod were nothing more "than kindly and friendly feelings." 277 He was moving on from his wife's death, and the desperate infatuation with her sister. Kautz's transfer to Newport Barracks located in Kentucky across the river from Cincinnati, Ohio marked a pivotal chapter in his personal life.

\section{Newport Barracks, Kentucky: 1872 - 1873}

Three days after August arrived at Newport Barracks, he was introduced to Fannie Markbreit. ${ }^{278} \mathrm{He}$ noted Fannie's presence several times in his journals. On June 2, 1872, he wrote that his day was spent being “...entertained by Miss Markbreit whose visit still continues." August was unimpressed with the tenacious Fannie after their initial meeting, and her lingering presence raised his suspicions regarding her intentions in staying with the Conrad's. August guessed the reason for her extended stay. On June 21 August wrote, "I spent the entire day in the garrison. The weather was very warm, Mrs. Conrad and Miss Markbreit spent a great portion of the day in my quarters." 279 August was seemingly exhausted by the constant presence of Mrs. Conrad and Fannie; "Miss M. seems to me to be more or less in the way and I do not understand why she is spending her time here. I have suspected that it is at Mr. \& Mrs. Conrad's instigation with a view to

\footnotetext{
276 Kautz, Biography of a Civil War General, 190.

277 A.V.K. Journal, July 11, 1872.

${ }^{278}$ Kautz, Biography of a Civil War General, 194.

${ }^{279}$ A.V.K. Journal, June 21, 1872.
} 
my becoming interested."280 Though her presence was a continued topic in his journals, August did not hold Fannie in high regard. "Miss Markbreit is still a guest with Mrs. Conrad...I find Miss M. improves on acquaintance, but still she is far from being my idea of a woman. I should like to see her at home, in her every day life."281 Fannie's pursuit of August persisted, and on July 19, 1872, August was escorting her to her sister's after dinner with the Conrad's. ${ }^{282}$

By the end of August, his opinion of Miss Markbreit softened. He noted that he needed to be on his guard so as not to fall for her advances. "I had a pleasant evening and Miss Fanny continues to improve in my estimation of her character. I must be on my guard before I become too much interested. I do not know any person that is more suitable at the present time." 283 His familiarity and attachment increased, as he referred to her by her first name. He sensed his growing fondness as he tried to guard himself against her advances. On September 22, he wrote a letter to Fannie "now a growing interest of mine," admitting his true feelings, and his reservations, "I wonder if the latter will end in a like disappointment or something still more serious." ${ }^{284} \mathrm{He}$ called on her frequently, and began "debating very seriously the question of matrimony."285

After much internal turmoil, debate, and consultation with friends, he visited Fannie and proposed in October 1872. Despite months of pursuing

\footnotetext{
280 Ibid., June 21, 1872.

281 Ibid., June 23, 1872.

282 Ibid., July 19, 1872.

283 Ibid., August 30, 1872.

284 Ibid., September 22, 1872.

285 Ibid., September 28, 1872.
} 
August, she did not immediately agree. "She has asked until Wednesday to consult her mother and brother and has given me every encouragement that her answer will be favourable. I am quite relieved that I have made the proposal. I trust the action is wise and that the result may be a happy one."286 August was convinced the marriage would yield a degree of happiness, and that the match was a good one, though the marriage did not come without its sacrifices. Prior to their wedding, Fannie forbade August of talking about his deceased wife. "I met Miss Fanny at the Mercantile Library and we had a long talk and some explanations I learned a painful fact that the new love will not tolerate the old and I cannot talk with her whom I love most now about her whom I loved most in the past. This is natural but not without its pangs." ${ }^{287}$ Fannie was not referring to Kitty, August's first wife, but Charlotte Tod, his second.

Despite the ultimatum placed on August's proposal, he decided to proceed with his marriage to Fannie and on November 27, 1872, the two were married "without a serious mishap."288 August was forty-four at the time and Fannie twenty-four. The aforementioned ultimatum was perhaps an early indication of how his relationship with his much younger bride would develop. His life with his third wife diverged from his previous marriages. Fannie was from a well-off family, and her marriage to August came with expectations on her part. Her place in society was important to her, and her life in the military quickly turned

\footnotetext{
286 Ibid., October 6, 1872.

287 Ibid., October 10, 1872.

${ }^{288}$ Ibid., November 27, 1872.
} 
disappointing. Shortly after their marriage, Kautz received orders that took him and his new bride west. These orders came as they discovered Fannie was pregnant with their first child; many changes were coming for the newlyweds. ${ }^{289}$ August was able to delay travel until after their son was born. On the morning of September 12, 1873, August wrote at "about half past eight our son was born. Fannie conducted herself admirably through her labors." 290 The next few days, he wrote that mother and baby were in good health and continued to improve, but as of September 18, he had made no progress on choosing a name for their son. ${ }^{291}$ August and Fannie would eventually settle on the name Austin.

\section{Fort Garland, Colorado Territory: $1873-1874$}

Fannie's role as an officers' wife and new mother changed drastically when they moved to the remote Fort Garland, Colorado from the bustling Newport Barracks. An army wife's life on the frontier was far from glamorous. Nonetheless, Fannie brought her tenacity and social life with her. She cultivated and maintained an active social life at the posts where they were stationed.

The roles and experiences of officers' wives in the post-Civil War West are unique to the study of 19th-century women. They often lived outside the boundaries of conventional 19th-century womanhood, yet were regulated by the social rules and structural hierarchy of the United States military, to which their

${ }^{289}$ Kautz, Biography of a Civil War General, 197.

290 A.V.K Journal, September 12, 1872.

291 lbid., September 13-18, 1872. 
husbands belonged. ${ }^{292}$ The women had no official military status, yet they had a distinct role in the creation of the West and acted as agents of colonization through their relationship with the military.

The wives of officers were at the high end of garrison society. Wives of enlisted men and laundresses were below them in the military social ladder. While the wives of officers held a higher social rank, they were not officially part of the military. Laundresses, who were often the wives of enlisted men, were employed by and considered an official part of the military. If an officer died, his wife and family received very little support and were required to leave the post, whereas if a laundress lost her enlisted husband she would be allowed to stay. ${ }^{293}$

Fannie's experiences as an officer's wife defied many aspects of Victorian-era womanhood. The Cult of True Womanhood was the centerpiece of nineteenth-century white, middle class, female identity. ${ }^{294}$ True Womanhood defined the main attributes of a good wife, mother, and woman. The main characteristics by which a woman was judged by her husband, by society, and by herself included piety, purity, submissiveness, and domesticity. ${ }^{295}$ While the United States expanded westward, the definition began changing to accommodate the differing environments. Women's roles in work evolved as their

\footnotetext{
292 Michele Nacy, Members of the Regiment: Army Officers' Wives on the Western Frontier, 1865-1890, (Westport, Conn: Praeger, 2000), 9.

${ }^{293}$ Miller Stewart, "Army Laundresses: Ladies of the 'Soap Suds Row," Nebraska History 61:421-36. Laundresses were the only women recognized by the United States military, their role was unique and distinctly different to officers' wives who chose to follow their husbands.

${ }^{294}$ Mary Louise Roberts, "True Womanhood Revisited," Journal of Women's History 14, no. 1 (2002), 150.

${ }^{295}$ Barbara Welter, "The Cult of True Womanhood: 1820-1860," American Quarterly 18, no. 2 (1966), 152.
} 
labor was needed in the successful establishment of homes and farms; their roles began to be defined outside of the private sphere. ${ }^{296}$

An examination of these attributes does not accurately reflect the situation with which Fannie Kautz was faced. Her work as the wife of an army officer was not to establish a farm, so her time was not spent performing physical labor to settle the land by building a home and community. As a woman in the West, her support came from her husband's involvement in the military. Therefore, she was allowed to establish herself outside of her expected role, and in the public sphere. The current study of officers' wives does not give us an adequate answer regarding their expected roles, as the military did not include them in their regulations. Yet we can surmise that officers' wives were given temporary relief from the strict confines of the Cult of True Womanhood while stationed with their husbands at Western forts, though they were still expected to adhere to the standards of womanhood. Officers' wives, who often came from wealthy families, brought their social ideals to Western forts that often forced them to reconfigure their own idea of femininity. ${ }^{297}$ We can establish that Fannie strayed from traditional female roles--she learned to fish at Fort Garland, and actively participated in and championed for a theater group while stationed at Fort Whipple. 298

\footnotetext{
${ }^{296}$ For more information on the Cult of True Womanhood in the American West and the changing roles of women see: Elizabeth Jameson, "Women as Workers, Women as Civilizers: True Womanhood in the American West," Frontiers: A Journal of Women Studies 7, no.3 (1984):1-8. 297 Verity G. McInnis, "Indirect Agents of Empire: Army Officers' Wives in British India and the American West, 1830-1875," Pacific Historical Review 83, no. 3 (2014), 378-409.

${ }^{298}$ Kautz, Biography of a Civil War General, 201.
} 
It was not the glamorous life to which Fannie was accustomed, as she did not have the same access to social gatherings that she had at Newport Barracks. Nevertheless, the adventure and excitement of frontier life likely appealed to her in some respects. Had she arrived in the West even a decade before, Fannie's world would have been dramatically different. Traveling in the West during the 1870 s was vastly different from the preceding decades; infrastructure and frontier safety developed at a significantly greater rate when the nation was not at war. Nevertheless, even though the Civil War was over, Fannie and August were heading west during a violent period. Arriving at the end of the 19th century surely altered Fannie's frontier experience. The perils and discomforts of traveling and living at frontier posts were still present, but undoubtedly, conditions had improved.

Life on a frontier post was filled with fear and loneliness, sentiments reflected in the memoirs and journals of many officers' wives, including Alice Blackwood Baldwin and Alice Kirk Grierson. ${ }^{299}$ Alice Blackwood Baldwin was eight months pregnant when her husband received orders to transfer to New Mexico in 1867. They started the journey from Fort Harker, Kansas, in September. While the command was passing through Colorado in mid-October, Mrs. Baldwin gave birth to their daughter. The command could not wait for her,

${ }^{299}$ Alice Blackwood Baldwin, An Army Wife on the Frontier: The Memoirs of Alice Blackwood Baldwin, 1867-1877, (Utah, the Mormons, and the West: No. 6. Salt Lake City: Tanner Trust Fund, University of Utah Library, 1975). Alice Kirk Grierson, and Shirley A. Leckie, The Colonel's Lady on the Western Frontier: The Correspondence of Alice Kirk Grierson, (Women in the West. Lincoln: University of Nebraska Press, 1989). 
so she and her newborn stayed behind and rejoined her husband at Fort Wingate several weeks later. ${ }^{300}$ Alice Kirk Grierson's description of her family's living arrangements at Fort Gibson, Oklahoma in 1868 provides insight into how even an officer was not guaranteed satisfactory living quarters, and the army made no regulations or special provisions for wives--not even officers' wives. ${ }^{301}$ Originally housed in a tent, the Grierson family then moved into the basement of their assigned home. Their basement accommodations proved even less desirable than the tent--along with her motherly and household duties, Mrs. Grierson was constantly protecting her newborn baby and small children from being crushed by falling plaster. ${ }^{302}$

The Kautzes departed Ohio on November 10, 1873, and arrived in Colorado at Fort Garland eight days later. ${ }^{303}$ The same trip could easily have taken many perilous months without access to the railroads. Increased access to trains made the journey faster and much less dangerous. The couple's arrival at Fort Garland was not just a drastic change for Fannie. When the recently widowed August arrived out West in 1869, he could pack all his belongings and move with ease. When he arrived in Colorado with his family in 1873 , Fort Garland had completed buildings, and the Kautzes were accompanied by five

\footnotetext{
300 Blackwood Baldwin, 4.

${ }^{301}$ Sandra L. Myres, "Romance and Reality on the American Frontier: Views of Army Wives." The Western Historical Quarterly 13, no. 4 (1982), 418.

${ }^{302}$ Grierson \& Leckie, 23.

${ }^{303}$ A.V.K. Journal, November 10-18, 1873.
} 
large wagons containing their furniture and belongings--including Fannie's piano and their healthy newborn son. ${ }^{304}$

Fannie wasted no time in bringing a social life to the post. She hosted dinners, entertaining men and ladies from the post as well as the settlers of the surrounding area. They hired the wife of an enlisted soldier, Mrs. Hare, to help care for their home, though when she was ill August commented, "Fannie had to do her own housework." ${ }^{305}$ August spent his evening in his home with Fannie, who often "amused herself with the piano." 306 Fannie hosted, with the help of Mrs. Hare, a multi-course meal on Christmas Day just over a month after their arrival. ${ }^{307}$ August commented in his journal that they were at the table for three hours for dinner alone and everyone enjoyed themselves. ${ }^{308}$ Fannie was determined to maintain a standard of society and company. While stationed at Fort Stanton, she learned to ride horseback and fish for trout, as these were some of her husband's interests. ${ }^{309}$ August seemed to find peace in his own life at this post, spending his days at home playing with his son, working in his wood shop or reading, rather than spending time at the garrison, as he did at other posts. ${ }^{310}$ Fannie's efforts in making Fort Garland her home did not go unnoticed by August, "I am very much gratified that my wife seems so contented. She never

\footnotetext{
${ }^{304}$ Kautz, Biography of a Civil War General, 199-200.

305 A.V.K. Journal, December 2, 1873.

306 Ibid., December 2, 1873.

307 Kautz, Biography of a Civil War General, 201.

${ }^{308}$ A.V.K. Journal, December 25, 1873.

${ }^{309}$ Kautz, Biography of a Civil War General, 201.

${ }^{310}$ A.V.K. Journal, December 30, 1873.
} 
talks of any plan in the future except when we can go to Europe together." ${ }^{111} \mathrm{His}$ experiences are markedly different from those he spent with his family at Fort Nisqually. He never wrote about playing with his sons Nugen and Gus, nor did he entertain future plans with Kitty. There is no evidence he even asked Kitty what her future plans were.

On July 8, 1874, Kautz received an appointment as Colonel of the 8th infantry, a promotion that came with orders to Arizona. ${ }^{312}$ The Kautzes popularity among their neighbors, military and civilian alike, was evident in the ball thrown in their honor on July 30 in the village of Culebra, "it passed off pleasantly and was well conducted." 313 The Kautzes returned to Ohio for a brief visit with family before heading to their post at Fort Whipple, Arizona. While in Ohio, they hired as their nurse a nineteen-year-old African American woman named Julia Pauline Robinson who would remain with the Kautz family for many years. ${ }^{314}$ The Kautzes not only had the means to hire a servant, but they were able to pay for her to travel with them, rather than counting on another enlisted soldier's wife. The Kautz family and their new nurse left Cincinnati for San Francisco on September 3, 1874. Throughout the journey, August commented with pride in the growth of his son--“our little boy is improving all the time." ${ }^{315}$ On October 31 ,

\footnotetext{
311 Ibid., December 31, 1873.

312 Kautz, Biography of a Civil War General, 202.

${ }^{313}$ A.V.K. Journal, July 30, 1874.

${ }^{314}$ Kautz, Biography of a Civil War General, 203; On April 8, 1892 the Kautz family received word that Pauline had married a white man named Andrew Streffeler. August's journal reflected, "I never believed that she would be so unwise as to marry a white man" (251).

${ }^{315}$ A.V.K. Journal, September 3, 1874, September 9, 1874.
} 
1874, after a nearly two-month-long trip by train, steamer, and wagon, they arrived at Fort Whipple. ${ }^{316}$

Fort Whipple, Arizona Territory: $1874-1878$

Fort Whipple, located near the mining town of Prescott, Arizona, was set against a beautiful backdrop of pine-forested granite mountains. ${ }^{317}$ George Crook and his wife Mary greeted the Kautzes. Crook had accepted the assignment of Commander of the Department of Arizona in 1871, three years before the Kautzes arrived. Under Crook's command, the region was fraught with violence. ${ }^{318}$ Lieutenant Colonel Crook was ordered to Arizona to pacify the Apache and return them to their reservations. ${ }^{319}$ Crook's campaign from September 1872 through April 1873 successfully forced all the bands of the Apache, except the Chiricahua, onto reservations. ${ }^{320}$ Crook's efforts brokered a halt in violence that led to relatively peaceful relations in the region upon Kautz's appointment as Commander of the Department of Arizona. Crook's tactics and success would earn him a promotion and transfer to the Department of the Platte to fight the Sioux, Cheyenne, and other Plains tribes. ${ }^{321}$

\footnotetext{
316 Ibid., September 3, 1874-October 31, 1874.

317 Grierson \& Leckie, 165.

${ }^{318}$ Kautz, Biography of a Civil War General, 201. The violence in Arizona leading up to Crooks appointment culminated into what is now referred to as the Camp Grant Massacre. Karl Jacoby's Shadows at Dawn: An Apache Massacre and the Violence of History presents an overview of the massacre where Anglo-American, Mexican American, and Tohono O'odham men murdered around 140 Aravaipa Apache men, women, and children encamped under the military's protection near Camp Grant.

${ }^{319}$ Charles Elliott, "An Indian Reservation Under General Crook," Military Affairs 12 (1948), 92.

${ }^{320}$ Kautz, Biography of a Civil War General, 204.

${ }^{321}$ Elliot, 92.
} 
Fort Whipple was established in $1864 .^{322}$ Theater at Fort Whipple first arrived in the spring of 1868 , six years before the Kautzes arrived. ${ }^{323}$ While it seemed participation was originally focused on enlisted men, it eventually included officers, their wives, and even their children. ${ }^{324}$ Current scholarship on women's participation in theater at military posts is limited. ${ }^{325}$ Perhaps the dull monotony of frontier forts and the isolation of the frontier allowed for the public participation in such activities by women. Historian Mary Louise Roberts identifies theater, a public performance, as a resistance to the Cult of True Womanhood. ${ }^{326}$ White middle-class women were previously confined to the privacy of home and family; participation in the public sphere associated "public women" with prostitution. ${ }^{327}$ The late eighteenth century began to see a shift in perspective concerning theater and women. While men could attend performances by themselves, women spectators needed to attend in groups, or be chaperoned by parents or spouses. Women were beginning to emerge as

\footnotetext{
322 Ray Brandes, "A Guide to the History of the U. S. Army Installations in Arizona, 1849-1886," Arizona and the West 1, no. 1 (1959), 54.

${ }^{323}$ Tom Collins, "Days Past: Soldiers Catch The Acting Bug in Territorial Prescott," Daily Courier, January 5, 2014. https://www.dcourier.com/news/2014/jan/05/days-past-soldiers-catch-theacting-bug-in-territ/ (Accessed May 20, 2018).

324 Thomas Collins, Arizona on Stage: Playhouses, Plays, and Players in the Territory, 18791912, (Guilford, Connecticut, 2016), 5.

${ }^{325}$ Helen Chinoy, and Linda Walsh Jenkins, Women in American Theatre: Careers, Images, Movements: An Illustrated Anthology and Sourcebook. 1st ed. (New York: Crown Publishers, 1981), provides a comprehensive analysis of women in American Theater from the 19th and 20th Century. Includes the varied roles; actress, playwrights, audience, etc., In its entirety, there is no critical analysis of military theater and women's participation which indicates a gap in the area of study. Tom Collins' research into theater, Arizona on Stage: Playhouses, Plays, and Players in the Territory, 1879-1912, provides a unique look into theater throughout Arizona Territory, and specifically in Prescott.

${ }^{326}$ Roberts, "True Womanhood Revisited," 153.

${ }^{327}$ Faye E. Dudden, Women in the American Theatre: Actresses and Audiences, 1790-1870, (New Haven: Yale University Press, 1994), 3.
} 
performers; in the 1790s, Susanna Rowson gained popularity, and in the 1840 s Charlotte Cushman was known as the greatest American actress of the century. ${ }^{328}$ While these actresses were respected, they still faced barriers. Charlotte Cushman's success and acceptance by audiences began to alter the definition of a "public woman," dissociating the term with sexuality. 329

Prior to the arrival of theater productions, Prescott, Arizona was rampant with drunken soldiers. The theater was welcomed by military authority and the town alike, as it kept the soldiers occupied, entertained, and out of the saloon. The 14th Infantry arrived at Fort Whipple in the spring of 1868, bringing with them the distractions of theater. The group called themselves "The Camp Whipple Dramatic Association." ${ }^{330}$ Audiences consisted of officers, soldiers, and townspeople and performances were held in the Prescott Theater, which had three magnificent chandeliers and velvet stage curtains. ${ }^{331}$ Crook arrived at Fort Whipple in 1872, and his wife Mary broke the gender barrier by performing on stage for the first time soon thereafter. Previously, shorter men played the female roles, but in October 1873, Mary Crook acted in the leading female role of "Trying It On." ${ }^{32}$ Daughters of Colonel John J. Wilkins were also regular participants; the pregnant Fannie Kautz directed one play in early February of $1875 .{ }^{333}$ The

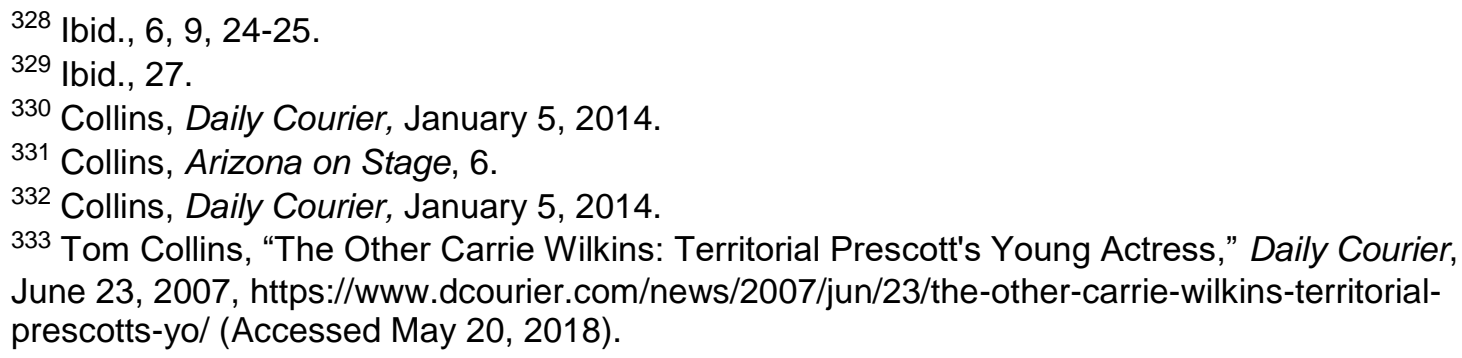
June 23, 2007, https://www.dcourier.com/news/2007/jun/23/the-other-carrie-wilkins-territorialprescotts-yo/ (Accessed May 20, 2018). 
Kautzes welcomed their second child, a daughter named Frances, or Frankie, two months later on April 11, 1875. ${ }^{334}$

The Arizona Miner frequently reported on the shows put on by the Camp Whipple Dramatic Association. Describing Fannie's performance on October 22, 1875, they reported she performed with Colonel Martin "to such perfection that one would almost believe they had been in the business before." 335 The performances continued, and Fannie's role in January 1876 as Mother Carey was a "decided success." She was commended by the editor of the Arizona Miner. "Mrs. Kautz rose to something of that dramatic fervor and force that catches its inspiration from a complete absorption of all individual thought and action into the passion of the play." 336

The current scholarship does not provide insight into women's accepted roles in public theater at western military forts. The continued problem cited for women actors is identified as the "body problem"; by placing themselves in public, women were sexually objectified. ${ }^{337}$ There is no evidence that Fannie, Mary Crook, or the Wilkins girls experienced this--at least not from a documented public perspective. Perhaps the women's status as the wives and daughters of officers awarded them a degree of protection from public scrutiny and allowed them to participate in public performances. They were not objectified or commodified; rather, they were encouraged and celebrated. Fannie was noted as

\footnotetext{
${ }^{334}$ Kautz, Biography of a Civil War General, 205.

${ }^{335}$ Arizona Miner, October 22, 1875.

${ }^{336}$ Arizona Miner, January 7, 1876.

${ }^{337}$ Dudden, 3.
} 
director of several comedy productions, praised for her acting and singing skills, and often publicly encouraged to put on more shows as reported in the Arizona Miner.

The last years as the Head of the Department of Arizona proved to be the most difficult in Kautz's career. Corrupt government officials and Indian agents, along with businessmen and local merchants in Arizona, formed a group collectively known as the "Tucson Ring." The group perpetuated and instigated Indian and white conflicts in order to secure federal contracts. ${ }^{338}$ Kautz and other military leaders critiqued the way the Indian agents conducted business. When ordered to remove Indians from the White Mountain Reservation, Kautz wrote to his superior, General Schofield, that the main proponents for removal were the civilian contractors in Tucson who would profit from relocating the reservation. General Schofield shared his views, reporting on the irregular manner in which the removal had taken place. ${ }^{339}$

In May 1876, Kautz received orders to close the Chiricahua Reservation and remove the Indians to the San Carlos Reservation; the leaders of three other small bands of Chiricahua agreed to go to the San Carlos Reservation in southeastern Arizona. The three leaders--Nolgee, Juh, and Geronimo--fled to Mexico instead. This failure provided an opportunity for the Tucson Ring, and on August 21, 1876, a petition circulated demanding Kautz's resignation. Arizona Governor Safford as well as other government officials and merchants signed the

\footnotetext{
338 Wooster, 349.

${ }^{339}$ Kautz, Biography of a Civil War General, 207.
} 
petition. Attempting to emphasize Kautz's incompetence, Governor Safford wrote to Kautz, claiming that further violence committed by Indians was not addressed by the military. Kautz received reports from the department inspector and accused the Governor of lying, as no citizens had come forth regarding any specific attacks. ${ }^{340}$ Other Army officers blamed the corrupt agents and civilians for the continued conflict in the region. General Crook voiced his frustrations, stating that there was too much money to be made "in times of Indian troubles." 341

Tragedy would later befall the Kautzes when Fannie delivered a stillborn daughter on June 12, 1877, “About seven o'clock P.M. a girl was born dead. Death had evidently occurred several days before birth." 342 August and the doctor remained by Fannie's side; the doctor was unable to determine what caused the baby to be stillborn. The next day, Fannie had the baby christened by the chaplain, with the name of Lillie. ${ }^{343}$ The event greatly affected Fannie, and August did what he could to provide comfort. He brought her ice cream--not an easy treat to find in Arizona at the time--and rarely left her side. ${ }^{344}$

Losing a child no doubt affected Fannie deeply and, in turn, affected her relationship with August. Fannie wanted to return to Ohio to visit family in June 1877, but August wanted her to wait until he was able to accompany her. ${ }^{345} \mathrm{He}$

\footnotetext{
340 lbid., 208.

${ }^{341}$ Wooster, 348.

${ }^{342}$ A.V.K. Journal, June 12, 1877.

343 Ibid., June 13, 1877.

344 Ibid., June 13, 1877.

${ }^{345}$ Kautz, Biography of a Civil War General, 213.
} 
eventually yielded to her wishes, and Fannie went home in the month of August.

A group planned a farewell party before her departure; as reported in the Arizona Miner, Lieutenants Thomas, Wilhelm, Whitney, and Anderson arranged for the celebration. The Arizona Miner praised her contributions to the community through her charity and her performances: "Mrs. Kautz by her genial and kind disposition, lady-like deportment, munificent hospitality and openheartedness." 346 August accompanied his wife for the first leg of her journey and allowed Lieutenant George Anderson, who was on his way to West Point, to escort Fannie the remaining stretch to her destination. August would soon come to regret that decision. ${ }^{347}$

Revealed in a letter with a notation that it was never sent, their marriage was faced with much turmoil during this time. August's three-page letter dated October 12, 1877--four months after the miscarriage and two months after she left Fort Whipple with Anderson--provides insight into their relationship. The letter is addressed "My Poor Silly Wife," and the emotional excerpts reveal his pain and anguish as he accused her of infidelity while she was away.

You could not have stunned me more had you felled me with a blow, than you did by that dispatch you sent me from there. I am still dazed with it, and I have suffered an age. My cheek glows when people ask me about you and want to know where you are and what you are doing. I feel as if I had lost all self control, I can't sleep and have lost all ambition.

I was not blind, I was not jealous, when I saw that your preference was growing plainer and more manifest with each day of our journey. I trusted you implicitly. I did not believe that you would do

${ }^{346}$ Arizona Miner, August 17, 1877.

${ }^{347}$ Kautz, Biography of a Civil War General, 213. 
anything to compromise yourself, and I thought the safeguards I had placed about you whilst you remained together would protect you, and as soon as you separated I had hoped that vain fancy would pass away in the excitement of visiting your relations and old friends. I did not dream that within a week you would be planning, as your letters show, how you could be with him, and before you would have seen half your old friends whom you went to see you would be with him, how or in what manner I have yet to learn.

August's anguish is highlighted by both physical and mental distress. It appears that Fannie's growing attachments were obvious to August, yet he still chose to send her back home, escorted by the man for whom she was developing feelings. The safeguards August refers to in his letter did not seem to deter Fannie's infatuation. The realization of his wife's growing emotions for another man brought forth a time of reflection; "I did not know how dear you were to me until now that I think I have lost you." His letter further details his mental state and despair.

I have read and reread the letters from you, but whilst they were entirely satisfactory at the time of receipt, up to a certain time, to my mind now diseased they contain new ideas of an adverse nature, I can get no consolation from them. I now notice, which I did not before, that you have not mentioned Mr. Anderson in one of your letters by name. Why should you ignore him so completely to me, and ask Miss Emma what chance he would have to get back on the staff.

I imagine now that you were homesick, but not for me. You had parted from your lover only a day or two before, not knowing when you would see him again. Two days later he has seen the Lippincotts and they invite you to visit them, which is, two days later, followed by another, and as soon as your finery is ready you are gone. 
August's realization that Fannie and Anderson continued to pursue whatever relationship they shared inspired him to return to all the other correspondence he had received from his wife since her departure. With his realization, a deeper meaning became apparent in her previous letters. Her trip plans changed based on Anderson's movements. The realization that Fannie and Anderson were still together made August realize the reason he had received no correspondence from Anderson as well; "Mr. A. promised to write to me, but I have not received a line since I parted with him at Wingate." August had arranged for Anderson to escort Fannie back home and had expected updates; Anderson's lack of communication no doubt fueled August's concerns of infidelity.

I cannot for a moment allow myself to think that you have been criminal, but you have put yourself where you are suspected, where they will talk about you as they did Mrs. Martin and him. I am no doubt regarded as an old fool who has married a young wife, and it seems to me now very properly so, for you have often made me feel great doubt where it was wise in me to marry one so much younger than I was.

Perhaps August thought Anderson's history of compromising the reputations of married women would be a warning to Fannie to deter her from pursuing Anderson's affections, so as not to ruin her own reputation. Throughout the letter, August hints at disbelief and struggles with Fannie's motivations for visiting Anderson. His blame and anguish are almost entirely directed at himself. "I am no doubt to blame, and perhaps I have not given you sufficient attention and not made enough display of my real affections for you." Though he accepted 
most of the responsibility, the blame inflicted on her highlights a deeper issue within their relationship: their age difference. Despite absorbing a majority of the blame, he does attribute fault to Fannie in this regard. "If I was wrong in seeking you on account of me being much older than you, you were quite as wrong in taking me." Though his letter shows the depth of his anguish, it also shows hope for the future.

If the order comes soon I will go to you in the hope that you may in some way convince me that you are true to me. If you care for me it was a great mistake to go away from me. You must have observed in my letters that I had some misgivings that we might regret the separation. How bitterly I reproach myself that I allowed you to go without me. ${ }^{348}$

August's letter, while desperate and emotional, presents his hopes and desires to be reunited with Fannie. August's journal entry of the same date as the letter expresses his depression. He does not mention Fannie's infidelity, but he writes that he visited the grave of their lost baby and desired to receive permission to go after Fannie. ${ }^{349}$ The entries from the following days mention his depression, his preparations to travel, and his struggles to sleep, but make no direct mention of Fannie's possible infidelity. While we may never know whether she was indeed unfaithful, it is evident the couple overcame this chapter in their relationship. August was reunited with Fannie in Ohio by November 1877.350

\footnotetext{
${ }^{348}$ August Kautz Letter to Fannie Kautz (unsent), October 12, 1877, Box 7, August V. Kautz Papers, Manuscript Division, Library of Congress, Washington, D.C.

${ }^{349}$ A.V.K. Journal, October 12, 1877.

${ }^{350}$ Kautz, Biography of a Civil War General, 214.
} 
Figure 2. Timeline: August and Fannie Kautz \& U.S. Western Posts, 1861 - 1892

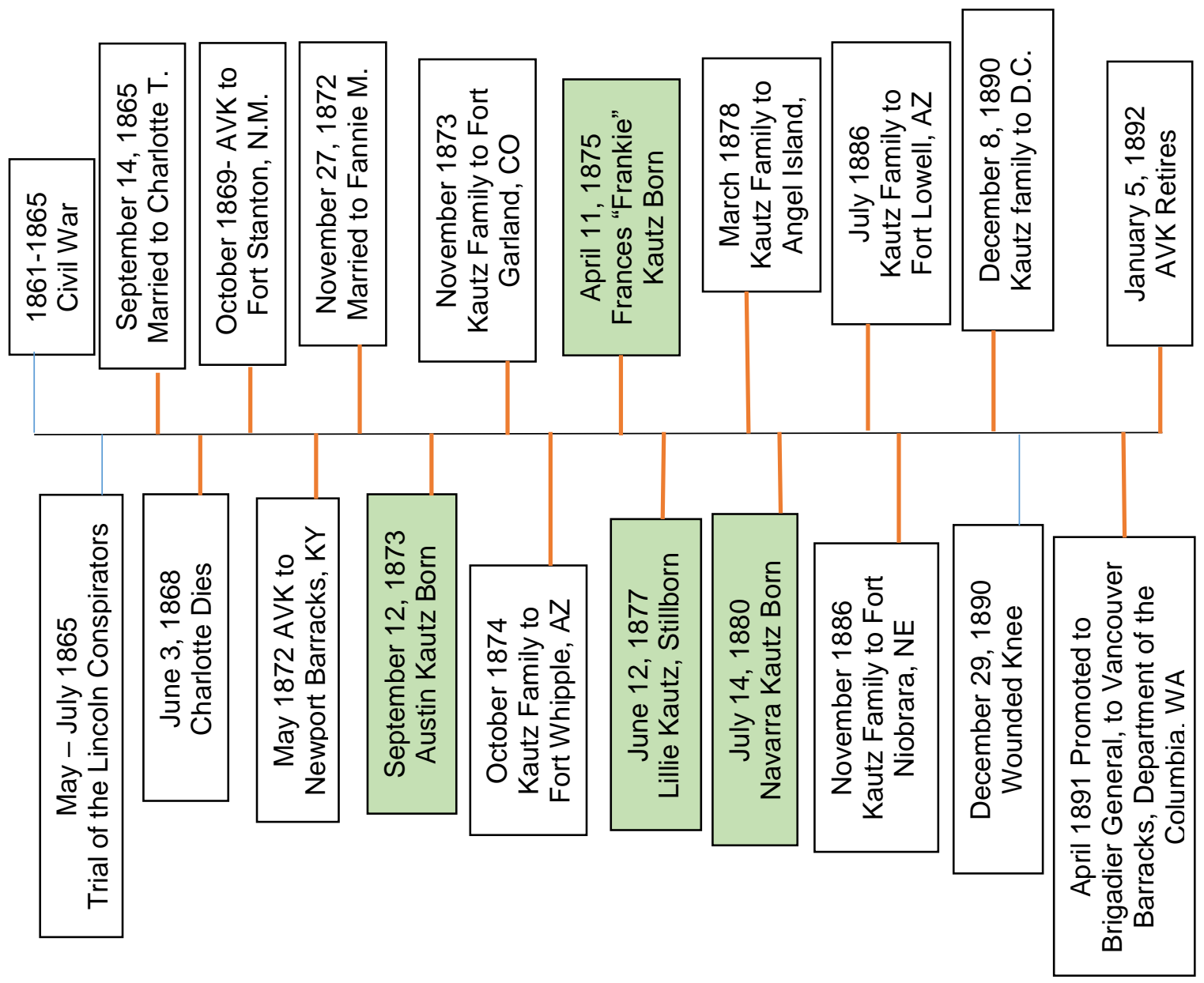

Amidst much professional and personal anguish, Kautz received notice of his transfer from Fort Whipple on February 20, 1878. Colonel Orlando Wilcox would take over at Fort Whipple while Kautz and his family went to Angel Island, near San Francisco, California. Kautz tried to remain in Arizona, but his efforts were not successful; he finally reconciled himself with the reality of military life, but Fannie was not as welcoming of the change. ${ }^{351}$ Perhaps it was her newfound talent and passion for theater--or, perhaps, she felt tied to the place where her

351 Ibid., 216. 
daughter was buried. Most likely, it was a combination of the events of the last three years. Regardless of her sentiments, the family would move.

\section{Angel Island \& Benicia Barracks, California: 1878 - 1886}

The Kautz family left Fort Whipple on March 12, 1878, and arrived at Angel Island nine days later--a relatively quick journey made possible by the Southern Pacific rail line. ${ }^{352}$ Kautz was greeted at his new post with news that he was to be court-martialed. A few months previously, Kautz served on the courtmartial of Captain Campbell accused of misappropriation of government funds. After the sentencing, Kautz received orders to send copies of the Judge Advocate's revisions to the court's sentence to all the officers involved in the case. Kautz also included notes of his own, and the Judge took offense to these comments. The Judge recommended Kautz be charged with "Conduct Prejudicial to the Good Order and Discipline of the Army." 353 Since the extracts were going to be made public regardless, Kautz saw no fault in his actions and felt confident in his position. He chose to represent himself in court, forgoing legal representation. ${ }^{354}$ Kautz arrived in Omaha at the end of April 1878 for his courtmartial; he was found not guilty and was on a train to San Francisco to resume his command on May $11 .{ }^{355}$ After three short months at Angel Island, August

\footnotetext{
352 Ibid., 217.

${ }^{353}$ Newspaper Article dated May 2, 1878, Scrapbooks, August V. Kautz Papers, Manuscript Division, Library of Congress, Washington, D.C.

${ }^{354}$ Kautz, Biography of a Civil War General, 217.

355 Ibid., 219.
} 
received the order to transfer his headquarters to Benicia Barracks, thirty miles northeast of San Francisco. ${ }^{356}$

Fannie attempted and failed to create a theatrical group at Benicia Barracks. Whether her failure was due to a lack of talent or lack of interest is unknown. Perhaps the location, near San Francisco, allowed for more hobbies and entertainment than at the more isolated Fort Whipple. In the spring of 1879 , Fannie channeled her artistic needs into painting. ${ }^{357}$ Kautz spent his time at Benicia Barracks avoiding any military conflicts; he spent his years stationed there attending to his duties, spending time with his family, and enjoying the outdoors. The family would take frequent camping trips and Fannie and August's relationship seemed to deepen.

In March 1880, Kautz received orders to move the 8th Infantry Headquarters back to Angel Island. ${ }^{358}$ In the two years since Kautz arrived in California, his career had grown stagnant. His personal advancements came in the time he spent with his growing family. Fannie went into labor with their fourth child early in the morning on July 13; after laboring for nearly a day, at about half past ten in the morning on July 14,1880 , "the mother was delivered of a fine healthy female child." 359 They called their new daughter Navarra, after the river where her parents camped and possibly, where she was conceived. ${ }^{360}$ Perhaps

\footnotetext{
356 Ibid., 220.

357 Ibid., 222.

358 Ibid., 224.

${ }^{359}$ A.V.K. Journal, July 13, 1880, July 14, 1880.

${ }^{360}$ Kautz, Biography of a Civil War General, 225.
} 
her birth symbolized a new start for the couple's relationship. After Navarra's birth, Fannie experienced regular bouts of sickness, and in August 1880, their five-year-old daughter, Frankie, contracted cholera. Perhaps because of her own ill health and that of her child, Fannie grew despondent. ${ }^{361}$ Mother and daughter eventually recovered.

August remained in California and focused on his family, doing little to advocate for his own career advancement. The next few years held no significant events; he and Fannie made frequent trips to San Francisco, and August regularly expressed in his journal the desire for his children's education and aspired that they learn both French and German. ${ }^{362}$ In April 1881, August met with Captain Wilkinson, "I had a short conversation with him about my boys at the Indian School at Forest Grove. He was enthusiastic in his praise of them, and told me I ought to be proud of them." ${ }^{363}$ August was no doubt proud of Nugen and Gus's success, as he always desired them to receive an education.

August's financial investments were not yielding much return and the family faced some financial strain. Despite his financial woes, he gave in to Fannie's pleading for a trip to Europe, leaving in April 1883. After traveling to Europe with his family, August eventually returned to California on November 30, 1883, arriving alone after settling his family in Europe. The next year, August lived with the freedom of a bachelor. He purchased a typewriter at the end of

\footnotetext{
${ }^{361}$ A.V.K. Journal, August 24, 1880.

362 Ibid., October 20, 1880.

${ }^{363}$ Ibid., April 6, 1881.
} 
1884 with the intent of working on his writing, but instead, the time was spent in melancholy in his family's absence. ${ }^{364}$

After a year and a half abroad, Fannie and their children returned on December 31,1884 . August had busied himself in October to receive his family in their home.$^{365}$ Their return home brought routine back to August's life, and his journals mentioned their time together, and their trips to the city. He and Austin regularly enjoyed playing chess and backgammon in the evenings after dinner. ${ }^{366}$

In June 1885, Kautz was called to inspect Fort Bidwell in Southern Oregon. Before leaving, he arranged for himself and Fannie to visit the Pacific Northwest, with stops at Vancouver Barracks, Olympia, Tacoma, and Steilacoom, where he introduced Fannie to his old friends Warren Gove and Edward Huggins. ${ }^{367}$ While in Tacoma August wrote, "Nugen and Augustus came to the Hotel to see me. They are well developed men and from all I can learn are well regarded by all who know them." ${ }^{668}$ There is no indication if Fannie met Nugen and Gus, but the next day August clearly visited them alone. He hired a horse and rode to the Puyallup Reservation, where many recognized him. He visited with his sons and saw their home; "I found the home of the boys quite primitive, but they have located on a very valuable tract of land, and by industry they will in time have a good home. They seemed gratified by my visit and I

\footnotetext{
${ }^{364}$ Kautz, Biography of a Civil War General, 229.

365 Ibid.

${ }^{366}$ A.V.K. Journal, January 19, 1885.

367 Ibid., June 29 1885, June 30, 1885

368 Ibid., July 1, 1885.
} 
satisfied that I went out to see them." 369 Nugen, Gus, and Kitty were listed on the Indian Census rolls in 1885; if August visited his sons on the reservation, he likely had the opportunity to see Kitty. ${ }^{370}$ August made no mention of Kitty, but he was happy to see his eldest sons and proud of the future they were creating for themselves.

On the Kautzes return trip to San Francisco, they stopped at Steilacoom, Port Townsend, and other sites that August had visited when he was in the Pacific Northwest nearly twenty years earlier. He noted that the country had not developed to the extent he had expected and reflected on his disappointment. ${ }^{371}$ August and Fannie arrived back in San Francisco on July 8. ${ }^{372}$ The rest of the year was marred by a series of tragedies for the family. Fannie's brother died, and she spent the year fighting bouts of illness and depression. Despite the trials they faced, August reflected on December 31,1885 , that his family was generally well; they were out of debt, and Frankie and Austin were doing well in school. ${ }^{373}$ August's end-of-year reflections do not comment on the wellbeing of his two eldest sons, and he had not mentioned them since he visited with them in July. August and Fannie made a trip to Washington, D.C., and Ohio to visit family in March 1886. While in D.C., August learned that he had been passed up for promotion, his frustration deepening when he learned that younger men had

\footnotetext{
369 Ibid., July 2, 1885.

3701885 United States Indian Census Rolls, 1885-1940, Digital Image Available at Ancestry.com.

${ }^{371}$ A.V.K. Journal, July 7, 1885.

372 Ibid., July 8, 1885.

373 Ibid., December 31, 1885.
} 
received promotions over him. August's journal notes that he had done little to advocate for himself; he believed experience and merit should account for promotions, not politics. ${ }^{374}$

\section{Fort Lowell, Arizona Territory \& Fort Niobrara, Nebraska: 1886 - 1890}

The continued conflict in Arizona with the Apache called Kautz back to the southwest, sending the family to Fort Lowell. The Kautz family began their trip to Arizona on July $1,1886 .{ }^{375}$ While stationed at Fort Lowell, Kautz received very few orders and there is no evidence to suggest he participated in any fighting. Word reached Fort Lowell on September 9 that Geronimo and his men had surrendered to General Crook in Mexico, virtually ending the decades-long struggle with the Apache ${ }^{376}$ Kautz's only role in the surrender was to provide a military band, cannon, and a speech. ${ }^{377}$ On November 4, Kautz learned he would be transferred again--this time to the Department of the Platte. ${ }^{378}$

The Kautzes arrived at Fort Niobrara, Nebraska, in November 1886, and quickly settled into their new routine. As the New Year approached, Fannie and August realized the lack of schools in the area would eventually be a problem and began discussions of sending their eldest children to boarding school. ${ }^{379}$ The

\footnotetext{
374 Ibid., March 21, 1886.

375 Ibid., July 1, 1886.

${ }^{376}$ A.V.K. Journal, September 9, 1886 \& Serna, "Mescalero Apache People." Geronimo and other leaders were sent to Florida and Fort Marion; the ones who survived were eventually able to return to their families on the reservation in Arizona. Daniel Herman's Rim Country Exodus details the struggles of the Apache, focusing on the years 1864-1934. Herman describes the conquest, removal, return, and renewal of Apache. A journey that has led them to both cultural and political sovereignty; "Though that sovereignty is fragile, it is theirs." (320)

377 Kautz, Biography of a Civil War General, 237-239.

${ }^{378}$ A.V.K. Journal, November 4, 1886.

${ }^{379}$ Ibid., December 31, 1886.
} 
following September, Frankie, and Austin were sent to stay with family in the east in order to receive a better education. Navarra, who was only seven, remained with her parents.

Fort Niobrara was located near the Rosebud Indian Reservation, and Kautz was often called there to mediate land disputes between settlers and the Indians. ${ }^{380}$ Kautz began to accept that he would not receive a promotion, disillusioned that it would not happen based on his record, but rather with one's personal influence with the President. ${ }^{381}$ In a letter to Major McKinley, Kautz reflected, "in time of peace politicians make the generals..." ${ }^{82} \mathrm{He}$ began to focus on his retirement and his investments to secure financial stability for himself and his family.

In 1890, a religious movement called the Ghost Dance swept through reservations across the western United States, promising to restore the land to the tribes and bring an abundance of game back to the region. ${ }^{383}$ While the dance was generally thought to be superstitious and delusional, settlers around the Pine Ridge Agency grew uneasy. ${ }^{384}$ The dance was inherently peaceful, but

\footnotetext{
380 lbid., August 31, 1887.

381 Ibid., December 31, 1887.

382 August V. Kautz Letter to Major McKinley, July 15, 1890, Box 7, August V. Kautz Papers, Manuscript Division, Library of Congress, Washington, D.C.

383 Hillstrom, 63.

${ }^{384}$ Jeffrey Ostler, The Plains Sioux and U.S. Colonialism from Lewis and Clark to Wounded Knee, Cambridge Studies in North American Indian History, (Cambridge; New York: Cambridge University Press, 2004), 244-245. The Rosebud Reservation neighbors the Pine Ridge Reservation, though the expansive lands separates Fort Niobrara and Pine Ridge by about 120 miles.
} 
white settlers associated it with impending conflict. ${ }^{385}$ Kautz noted that settlers from isolated farms in the region began moving into town for safety. ${ }^{386}$ As tensions increased, the military began to mobilize. Kautz received orders on November 18, 1890, to prepare troops to go to the Rosebud Agency the next morning and to inquire about the number of horses readily available at Fort Niobrara. Colonel Smith, Kautz's replacement, was ordered to "exterminate any Indians who opose him." 387 Kautz received orders to Washington, D.C., and left Fort Niobrara on December $8 .^{388}$

As a response to growing civilian concerns, the United States government dispatched troops from Fort Robinson, Fort Omaha, Fort Niobrara, and later troops from Colorado, Kansas, New Mexico, and California. ${ }^{389}$ On December 29, 1890, the mounting tensions reached their breaking point. Five hundred soldiers surrounded a peaceful group of approximately 350 Sioux. The soldiers separated the men from the women and children and began to collect their weapons. Many started to resist, as their weapons were their only means for hunting and protecting their families. A shot went off. The exact number is not known, but between 250-300 men, women, and children lay dead when the violence ceased. ${ }^{390}$ Initially described as a battle, survivors and eyewitnesses led to public

\footnotetext{
385 Jerome A. Greene, American Carnage: Wounded Knee, 1890, (Norman, Oklahoma: University of Oklahoma Press, 2014), 81.

${ }^{386}$ Kautz, Biography of a Civil War General, 243-244.

${ }^{387}$ A.V.K. Journal, November 18, 1890.

388 Ibid., December 8, 1890.

389 Ostler, 301.

390 Hillstrom, 3.
} 
scrutiny, and the incident quickly became known as a massacre. The soldiers and their commander, Colonel Forsyth, defended their actions. Twenty-five soldiers lost their lives, and seventeen soldiers later received Congressional Medals of Honor for their heroism in battle. ${ }^{391}$ General Nelson Miles arrived at Pine Ridge and relieved Forsyth from command, and ordered an official inquiry to determine if any noncombatants were unnecessarily injured or killed. Despite Miles' personal belief that Forsyth should be punished, he was cleared of all charges. ${ }^{392}$ Kautz reflected in his journal that he was grateful to have escaped being involved in the incident, and commented that all was done to instigate war, which he believed could have been avoided. ${ }^{393}$

The Wounded Knee Massacre was a culmination and direct result of American expansion and years of violence against Indigenous tribes in the American West. Manifest Destiny and American expansion came with a bloody price. The Wounded Knee Massacre marks the end of the "Indian Wars," but to end with Wounded Knee affirms the mythology of the "vanishing race." ${ }^{994}$ The consequences of colonialism on Indigenous tribes in the United States are still felt. Wounded Knee was the most devastating event in Plains Sioux history, but it did not destroy the Sioux nation. ${ }^{395}$

\footnotetext{
391 Hillstrom, 76.

392 Peter R. Demontravel, "General Nelson A. Miles and the Wounded Knee Controversy," Arizona and the West 28, no. 1 (1986), 34-38.

${ }^{393}$ A.V.K. Journal, December 31, 1890.

${ }^{394}$ Hixson, 185.

395 Ostler, 9.
} 


\section{Washington, D.C.: 1890 - 1891}

Kautz arrived in Washington, D.C., and impatiently awaited advancement as his fellow classmates received promotion. His final years in the military would prove to be a constant battle as he worked his way up to the rank of General, with hints of jealousy and discontent at his peers' successes. ${ }^{396}$ Post-Civil War military had very little opportunity for advancement, even for excellent soldiers. Promotion was dependent upon a vacancy, created by death or retirement, as well as political influence and favoritism. ${ }^{397}$ The final years of Kautz's career went without great incident, and timing kept him out of the major debacles of the United States Military.

After years of discontent and lack of promotion, Kautz spent the remainder of his career serving on boards in Washington, D.C., while lobbying for promotion. His journal and letters highlight his relative distaste for the political aspect of self-promotion. After seeing the success of his fellow West Point classmates, Kautz's ambition overcame his pride. He--and much to his dislike, Fannie--began to lobby for his promotion. Fannie formed friendships with those who could influence Kautz's promotions, throwing extravagant parties to ensure more connections were made, which exhausted August and their finances. ${ }^{398}$ August was forced to borrow money from various sources to pay their expenses.

${ }^{396}$ Kautz, Biography of a Civil War General, 229.

${ }^{397}$ Grierson, 189.

${ }^{398}$ A.V.K. Journal, February 9, 1891. 
Kautz's promotion finally came in April of 1891 . General Lewis Grant presented Kautz with a letter informing him that it was not important, and to read it at his leisure..$^{399}$ Kautz immediately recognized it as his appointment to Brigadier General, which included a much-needed pay raise for his family's stretched financial status due to Fannie's overspending. ${ }^{400}$

\section{Vancouver Barracks, Washington: 1891 - 1892}

Kautz's promotion to Brigadier General came with a final assignment to Vancouver Barracks and Head of the Department of the Columbia. The family moved to Vancouver, Washington on August 11, 1891, and Austin began school at Stanford in October. ${ }^{401}$ The few months that the Kautzes spent in Vancouver were pleasant and generally uneventful.

On January 5, 1892, Kautz retired from military service, closing his career at the same post it began nearly four decades previously. ${ }^{402}$ Kautz reflected on his departure from the military with optimism; he did not "feel any depression or disappointment" that he would no longer be in command. ${ }^{403}$ The family traveled to Ohio to visit family, then traveled to Europe again at Fannie's pleading. ${ }^{404}$ August returned from Europe on November 3, 1892, while his family stayed in Europe for more than a year. Fannie agreed to live on a strict budget, ultimately

\footnotetext{
399 Ibid., April 20, 1891.

400 War Department Military Correspondence, Box 4, August V. Kautz Papers, Manuscript Division, Library of Congress, Washington, D.C., \& Kautz, Biography of a Civil War General, 246. 401 A.V.K. Journal, August 11, 1891. Kautz, Biography of a Civil War General, 249.

402 A.V.K. Journal, January 5, 1892.

403 Ibid., January 5, 1892.

${ }^{404}$ Kautz, Biography of a Civil War General, 251.
} 
straying from it, forcing August to sell some of his property to pay for their return in December 1893. ${ }^{405}$

In his family's absence, August left for Washington Territory in early 1893, where he spent time with his two eldest sons. Nugen and Gus visited August in his hotel room. Reflecting on their visit, August wrote in his journal on January 13,1893 , that they had "reached full manhood, and while they are not what they might be, they are also not as bad as they might be. They seem to be making an honest living and Gus has two children, and Nugen one still living." 406 The meeting left August dissatisfied, and he noted that they were not very open about their affairs and they only stayed for an hour. He made no other mention of them on his trip.

To ensure the future of his son Austin, August secured him a place at Annapolis. Congressman William Doolittle offered Austin a seat at Annapolis, in exchange for August paying the Stanford tuition for a young boy to whom the congressman had an attachment. ${ }^{407}$ A majority of 1894 was spent in Ohio, where Fannie recovered from the removal of an ovarian tumor. ${ }^{408}$ The Kautz family-except Austin, who was at Annapolis--moved to Seattle in June 1895.

\footnotetext{
405 lbid., 252-253.

${ }^{406}$ A.V.K. Journal, January 13, 1893.

${ }^{407}$ Kautz, Biography of a Civil War General, 252.

${ }^{408}$ A.V.K. Journal, December 31, 1894.
} 


\section{Chapter Three}

"Nothing Worthy of Note Transpired": The Kautz Family Legacy

\section{Snoqualmie Falls, Washington - 1895}

The sound of the falls rushed over the old man as he watched his younger companions climb the rocks down to the base of the falls. He would have joined them in his younger days, but old age prevented him from the risky climb. He stared at the rushing water, pondering where his life had taken him. 409

The Kautz family moved to Seattle in 1895 , and it was at his home there that August died on September $4,1895 .{ }^{410}$ The days leading up to his death did not indicate any signs or symptoms other than general discomfort. His death was attributed to a lifelong history of ulcers and other digestive issues. He was temporarily buried in Seattle, before being removed to Arlington National Cemetery. ${ }^{411}$

Throughout his life, August's journals provided an almost daily insight into his life and that of his family; he wrote about his children, his wives, the weather, his finances, his career and the daily happenings of military life. When there was nothing to report, he would still include "nothing worthy of note transpired." This is possibly his most used phrase in over forty years' worth of journals. On December 31, 1894, he reflected, "I find that I write a great deal that is not of much value to anyone." ${ }^{412}$ His daily life--while often boring and mundane--tells a greater story unbeknownst to the author. His writings reflect a noteworthy life,

\footnotetext{
409 lbid., August 27, 1895.

410 Ibid., Journal Addendum, Frankie Kautz.

411 Kautz, Biography of a Civil War General, 257.

${ }^{412}$ A.V.K. Journal, December 31, 1894.
} 
filled with value when placed in the greater history of colonization and conquest of the American West.

\section{Kitty, Nugen \& Gus}

Washington Territory regulated Kitty's marriages, her rights as a mother, and her children's rights regarding their inheritance from their father. While August remained in contact with the boys to an extent, the evidence does not suggest he regularly interacted or communicated with Kitty. It seems they had some written communication, however--when Nugen was unhappy with his education, he states that his mother wrote to his father to make better arrangements. ${ }^{413}$

The legal system was designed to assert its power over Kitty and take away her personal autonomy; despite this, she navigated her life through losing her maternal rights, marriages, and divorce. While Kitty did not maintain legal guardianship over her sons, she was in contact with them, and along with August's social and economic standing, she was able to provide her sons with education. After August left, Kitty married William Diggins on July 3, $1875 .{ }^{414} \mathrm{Her}$ marriage to Diggins ended, though there is no evidence of when or why. She was able to acquire wealth--in the form of cattle and horses--and support her sons while they attended Union Academy in 1876 and 1877.415 As of 1885 , Kitty was

\footnotetext{
413 Lockley, "Biography - Kautz, Nugen," Oregon Historical Society.

414 "License Issued July 3, 1875, William Diggins and Kitty Kautz," Washington Marriage Records, 1854-2013, Thurston County, Washington State Archives, Digital image available at Ancestry.com.

${ }^{415}$ Lockley, "Biography - Kautz, Nugen," Oregon Historical Society.
} 
listed on the Indian census rolls in Washington Territory, and again in 1887 on the census report of the Indian Reservation in King County. ${ }^{416}$

Under the Dawes Act of 1887, the federal government divided tribal lands into individual allotments. ${ }^{417}$ The allotment policy dramatically reduced the amount of land owned by Indians, both collectively and individually; the goal was to destroy the reservation system. ${ }^{418}$ The large surplus of land left after the allotments were became available to white settlers and railroad companies for development. ${ }^{419}$ Kitty, Nugen, and Gus all filed for allotments on the Puyallup Indian Reservation. ${ }^{420}$

Kitty married again, Huggins stated, "she married a well to do farmer, an American, and lived with him, comfortable, apparently, until she died, some years ago." ${ }^{221}$ The well to do farmer was a man named Henry Walker. The exact date of their marriage is unknown, but she was with him at the time of her death. Allotment records for "Kittie" Kautz indicate that she was married to Henry Walker when she died. Upon her death, he could not inherit the titles to the land because he was a white man. Her land was bequeathed to her two sons, Nugen Kautz and Gus Kautz. ${ }^{422}$ Much like Celiast Smith, Kitty was able to navigate through her

\footnotetext{
4161885 United States Indian Census Rolls, 1885-1940, Digital Image Available at Ancestry.com, \& 1887 United States Census, King County, Washington State \& Territorial Census, 1857-1892. Digital Image available at Ancestry.com. 417 Glenn, 56.

${ }^{418}$ Asher, 18.

419 Glenn, 56.

${ }^{420}$ Allotment No. 136, Puyallup Indian Agency Series, Reports on the Status of Puyallup Indian Lands, 1896, National Archives and Records Administration, Seattle, Washington.

421 Huggins, "Biography - Kautz, A.V," Oregon Historical Society.

422 Allotment No. 136, NARA.
} 
changing world--abandoned by August; she married, divorced, and married again. At least to some degree, she was able to direct her life and make her own decisions.

The convoluted history of Washington Territory miscegenation laws would lead to the future problematic question of inheritance rights for mixed-race children. These children--usually the descendants of white men and Indian women--tried to assert their legal rights in a court system that did not favor them. August and Kitty's sons never brought their case to court, but when August died, the boys attempted to assert their legitimacy and take their share of the inheritance but were dissuaded from doing so. ${ }^{423}$ While it is uncertain why August did not include his two eldest sons in his will, there was a time in which he desired to provide for them, and felt a responsibility for their future financial wellbeing. It is ironic, then, that the man who dissuaded the boys from pursuing any inheritance from their father had once been in charge of ensuring they would receive their inheritance.

During the Civil War, August sent a letter to Edward Huggins regarding what would happen in the event of his death. August named Huggins and his brother, Fred Kautz, as executors. The letter, dated March 1, 1862, and sent from Washington, D.C. directed Huggins to sell all of his possessions, except his letters and books, and that the money should be "expended for the education of

\footnotetext{
${ }^{423}$ Huggins, "Biography - Kautz, A.V," Oregon Historical Society.
} 
Lugie and his brother." 424 August further instructed Huggins to ensure his sons inherit the land he purchased in Steilacoom, Washington Territory. "The lots in Steilacoom I feel satisfied will one day be valuable and my object in purchasing them originally was to hold on to them and give the children the benefit of them eventually, even if I should live." 425 August's plan was to give his sons the land to ensure their success into adulthood. Based on his final will, he did not leave his sons that property.

August concerned himself about his sons' futures, a sign that he did care deeply for them. While facing his mortality, he sought to ensure the wellbeing of his sons. The letter shows that August wanted his two sons to share in his successes. Before the Civil War started and August was called back east, he appointed Edward Huggins to help care for his sons before naming him the executor of his estate. ${ }^{426}$ August entrusted his sons' futures to Huggins.

While August wanted his two eldest sons to be given a share of his estate at one point in his life, they were not mentioned in his final will. Perhaps this was because they were older and had built their own lives. After August's death, the boys sought their inheritance and attempted to assert their legitimacy. The Daily Olympian reported that the late General's will would be contested by two Puyallup Indians, who claimed their father was the late Kautz. ${ }^{427}$ Edward

\footnotetext{
${ }^{424}$ August V. Kautz Letter to Edward Huggins, March 1, 1862, Edward Huggins Papers, University of Washington Special Collections, Seattle, Washington.

${ }^{425}$ Kautz, Edward Huggins Papers, UW Special Collections.

${ }^{426}$ Huggins, "Biography - Kautz, A.V," Oregon Historical Society.

${ }^{427}$ Daily Olympian, October 11, 1895.
} 
Huggins, in a letter to Eva Emry Dye, wrote of their attempt to legally claim their inheritance, "...some shyster lawyers persuaded the two boys to claim their share of the General's estate, but after an interview with Mrs. Kautz, they (the boys) abandoned the idea of troubling her..."

The degree to which Huggins was involved in setting up the interview with Fannie Kautz is unknown, but he felt that Gus and Nugen did not have a right to claim any of August's estate. Perhaps his justification was due to the common practice of military men having interracial relationships, "...almost all the early officers had Indian wives, and kept them openly in barracks, until the wives (American) of officers arrived.... The surviving Mrs. K was aware of the little episode in the life of General K." ${ }^{428}$ Huggins sentiments towards August are respect and familiarity. While he was once in charge of ensuring the two eldest of the Kautz boys would receive their desired inheritance from their father, he no longer felt it was his obligation to do so.

While the boys did not pursue a case to claim their share of their father's estate, the situation still raises the question: if they had not been deterred, would the court have viewed their claim as legitimate? Would they have been declared the rightful heirs of their father's estate? The uncertainty of their parents' marriage date plays a pivotal role in the answering of those questions. Two court cases, which occurred simultaneously in 1894, a year before August Kautz's death, provide insight into the court's decision-making precedent that

\footnotetext{
${ }^{428}$ Huggins, "Biography - Kautz, A.V," Oregon Historical Society.
} 
correlates along the same timeline as the Kautz family. In Legal Codes and Talking Trees, Katrina Jagodinsky examines two similar cases, indicating what the Washington Courts might have ruled. Like the relationship between August and Kitty, two sisters of the Duwamish tribe located in the Puget Sound region of Washington Territory married two white men, who would become prominent members of Seattle society for their part in building the city of Seattle. Salmon Bay Curley, a high-ranking member of the Duwamish tribe, saw the benefits of aligning himself with the white settlers. His daughter, Susan, chose Henry Yesler to be her partner; Yesler had another wife back east. Henry and Susan had a daughter named Julia, born on June 12, 1855. When Henry's other wife, Sarah, joined him in 1858, Susan and Julia moved out of the household; however, they continued to be supported by Henry. ${ }^{429}$ Susan's younger sister, Peggy, chose as her partner Franklin Matthias in 1857, and they had a daughter named Rebecca born December 29, 1859. ${ }^{430}$ These two couples began their relationships around the same time as August and Kitty, with children born along the same timeline as well. Jagodinsky asserts that both women 'chose' their partners, and while their father saw the benefits of partnerships with the incoming white settlers, the women did as well. The court upheld Rebecca's claim to her father's estate under the 1854 Marriage Act, which declared children legitimate if their parents

429 Jagodinsky, Legal Codes and Talking Trees, 139.

430 lbid. 
cohabited together. ${ }^{431}$ Julia was denied, based on a clause which barred mixedrace children from inheritance if children of a legitimate marriage existed. ${ }^{432}$

While Rebecca and Julia's parents' unions were similar to that of August and Kitty, the question of Rebecca's legitimacy did not solely determine the court's decision in her rights to his estate, as her father had no other children. The decision in Julia's case further increases the likelihood that the Kautz boys would not have been granted rights to their father's inheritance, as he had three children from a "legitimate" marriage. The legal system turned into a tool of colonization, even after violence ended. 433

Nugen and Gus went on to study at Union Academy in Olympia in 1876 and 1877. ${ }^{434}$ Nugen also studied at Pacific University for two years and became a teacher. ${ }^{435} \mathrm{He}$ married Elizabeth Olney and they had ten children, five of whom survived into adulthood. ${ }^{436}$ Nugen represented the tribe in legal matters, and he helped navigate the transfer of Indian lands during the allotment period. ${ }^{437} \mathrm{He}$ went on to teach at Forest Grove Indian School and lived with his wife's family on the Warm Springs Indian Reservation before settling in Portland, where he died

\footnotetext{
431 Brad Asher, Beyond the Reservation: Indians, Settlers, and the Law in Washington Territory, 1853-1889, (Norman: University of Oklahoma Press, 1999), 67.

432 Asher, 68.

433 Brad Asher's Beyond the Reservation: Indians, Settlers, and the Law in Washington Territory, 1853-1889 examines territorial court records for Indian presence in the lower courts, specifically involving cases of land rights and inheritance. Walter Echohawk's In the Courts of the Conqueror the: 10 Worst Indian Law Cases Ever Decided examines cases involving Indigenous people, and the ways in which the United States continues to use the legal system to deprive Native Americans of land rights and to justify federal policies that threaten tribal sovereignty. ${ }^{434}$ Lockley, "Biography - Kautz, Nugen," Oregon Historical Society.

435 Ibid.

436 Ibid.

${ }^{437}$ Carpenter, Nisqually Indian Tribe, 32.
} 
in $1938 .{ }^{438}$ Gus remained on the Puyallup Reservation, where he married a woman named Maria. They had four children: Granville, Emma Kitty, Julius, and Ada. ${ }^{439}$ Gus served as the Justice of the Peace on the Puyallup Indian Reservation. ${ }^{440} \mathrm{He}$ died in $1935 .{ }^{441}$ Descendants with the name of Kautz still live on the Nisqually and Puyallup Reservations today. ${ }^{442}$

\section{Fannie, Austin, Frankie, \& Navarra}

Fannie, Austin, Frankie, and Navarra's situation was not as complicated after August died. Their lives undoubtedly changed, but the legal system was set up to ensure the inheritance went to Fannie and her children; it protected their right to August's estate. When August died, Fannie did not continue paying the tuition of the Stanford student in return for Austin's appointment to Annapolis. In 1897, J.A. Hosher filed a suit against August's estate, providing evidence that August had paid Hosher's expenses until his death. Despite this, the judge dismissed the case and Fannie was not obligated to pay. ${ }^{443}$ The law protected her and her children's inheritance from August's oldest children and from Hosher.

Fannie died on August 11, 1913, while living with her daughter Frankie in New Jersey. She was buried in Arlington next to her husband. Austin married

\footnotetext{
438 Lockley, "Biography - Kautz, Nugen," Oregon Historical Society.

439 United States Department of the Interior, Washington Enrollment \& Allotment Applications of Washington Indians, 1911-1919, Digital Image available at Ancestry.com.

440 Tacoma Daily News, April 20, 1892,

441 Kautz, Biography of a Civil War General, 257.

${ }^{442}$ Cecelia Svinth Carpenter mentions the surname Kautz throughout all of her works. The Kautz name is also found in Charles F. Wilkinson's Messages from Frank's Landing: A Story of Salmon, Treaties, and the Indian Way. If you drive through the Nisqually Reservation around the Fourth of July, there is a firework stand set up with the name Kautz displayed.

${ }^{443}$ Tacoma Daily News, June 21, 1897.
} 
Louise Hovey, and together they had one son. He had a successful naval career, cut short by his death in 1927. He was buried in Arlington near his father. Frankie and Navarra lived long lives, with Frankie dying in 1962, and Navarra in 1970.444

August, an officer in the United States military, was an agent of colonization. He participated in violence and the relocation of Native people to reservations. Though he opposed the reservation system and thought it to be "fatal" and "destructive" to Indian people, he was first and foremost a soldier who followed orders. ${ }^{445}$ His relationship with Kitty was marked by his dominance over her, and his relationship with his two eldest sons was limited. He supported them financially for a portion of their lives but looked down on their living conditions when he visited with them as adults. August never indicated that he physically punished Fannie for her insolence, and yet his journals mark multiple instances of frustrations, including her overspending and her possible infidelity. August and Fannie's children received much more attention in his journals, and he was more involved in their lives compared to his eldest sons, having left them when they were just two and four years old.

Kitty learned to navigate her changing world and culture. In a time of political unrest, she chose to marry an officer in the United States military. While they were together, his station and position gave her and her children access to better medical care and other resources. When August left, he placed their children outside of her care, in the homes of white settlers. She navigated the

\footnotetext{
${ }^{444}$ Kautz, Biography of a Civil War General, 257.

445 Smith, View from Officers' Row, 107-108.
} 
rest of her life through marriage and divorce, asserting her agency and choices whenever she was able.

Figure 3. Kautz Family: Births, Marriages, and Deaths, 1828 - 1970

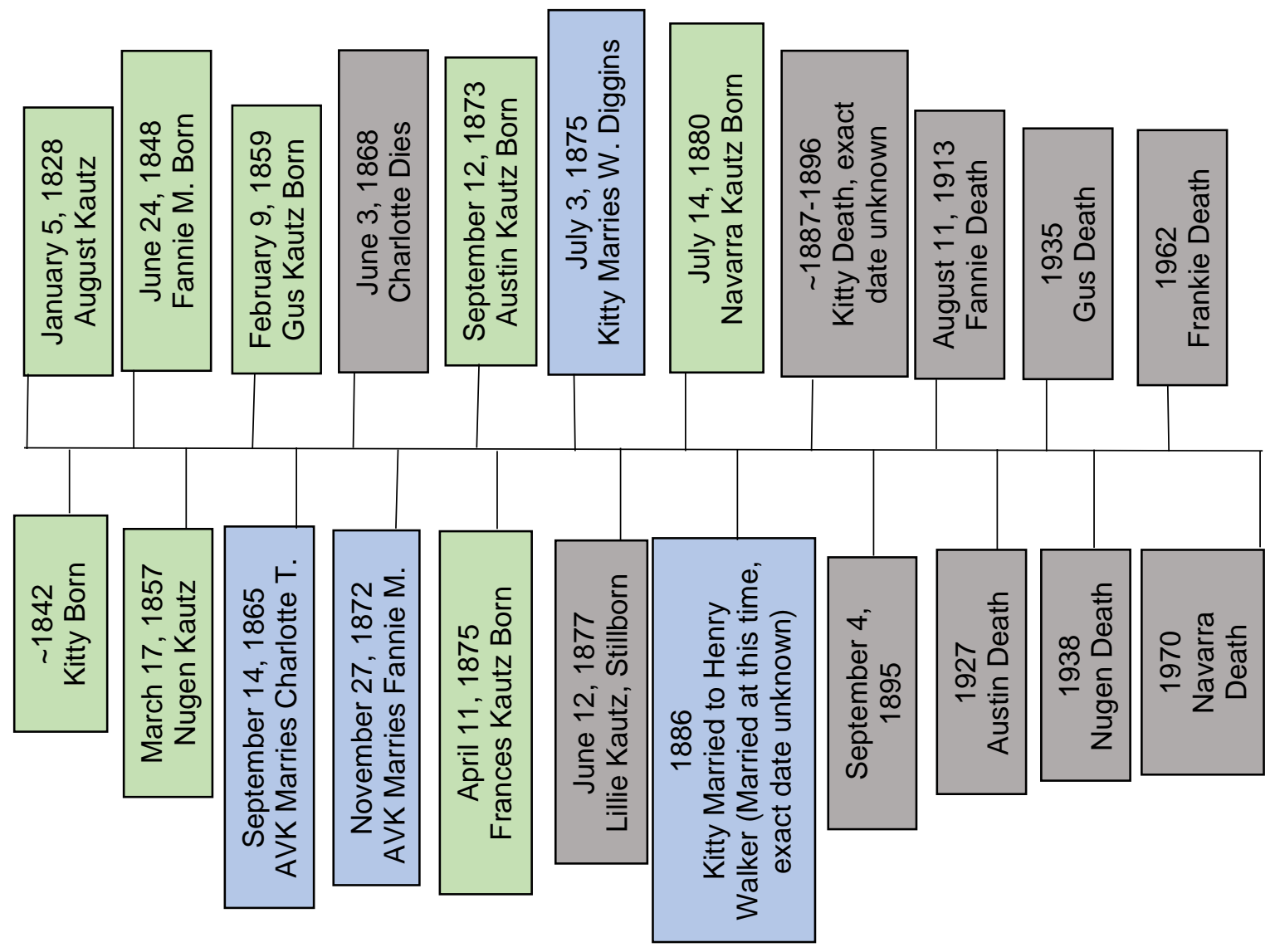

Fannie, as a white woman and the wife of an officer, also served as an agent of colonization. White women had greater freedoms in the West, in part because there was a need to attract more women to the region to increase settlement, reproduce culture, and physically bear children--all methods of 
unsettling Indigenous tribes. ${ }^{446}$ Fannie's status, position, and increased freedoms allowed her to participate in the spread of American culture in the West through theater. While her role was secondary and less violent, she was still an agent of colonization through movements in the military. Upon August's death, she and her children benefited from the rules of society that she and August had helped to construct--the same rules that disenfranchised Kitty and her sons.

The Kautz family history is not unique. They faced the same trials many families deal with; marriage, births, death, infidelity, financial struggles, separation, and complicated relationships. The importance of their family history lies within the scope of examining the effects of colonization. August married across racial lines and established families that within two generations span nearly 150 years, from his birth in 1828 to his youngest daughter's death in 1970 . Their family structure is uniquely set up to provide critical analysis of how white and Indigenous families both facilitated and navigated the colonization of the American West.

${ }^{446}$ Margaret Jacobs, "Western History: What's Gender Got to Do With It?" Western Historical Quarterly 42, no. 3 (2011), 297-304. 


\section{Bibliography}

\section{Primary Sources}

Archival Collections, Government Documents:

Allotment No. 136. Puyallup Indian Agency Series. Reports on the Status of Puyallup Indian Lands, 1896. National Archives and Records Administration. Seattle, Washington.

“Biography - Kautz, A.V." Vertical File. Main floor. Oregon Historical Society.

"Biography - Kautz, Nugen”. Vertical File. Main floor. Oregon Historical Society.

Guardianship Case 1867, Augustus Kautz. Pierce County, County Clerk, Probate Case Files. Puget Sound Branch, Washington State Archives.

August V. Kautz Papers. Manuscript Division. Library of Congress. Washington, D.C.

Kautz, August. "Letter to Edward Huggins." March 1, 1862. Edward Huggins Papers. University of Washington Special Collections. Seattle, Washington.

"License Issued July 3, 1875, William Diggins and Kitty Kautz." Washington Marriage Records, 1854-2013. Thurston County. Washington State Archives. Digital image available at Ancestry.com

United States Department of the Interior. Washington Enrollment \& Allotment Applications of Washington Indians, 1911-1919. Digital Image available at Ancestry.com.

United States Department of the Interior, Office of Federal Acknowledgement. "Summary Under the Criteria and Evidence for Proposed Finding Steilacoom Tribe of Indians," January 14, 2000.

https://www.bia.gov/sites/bia.gov/files/assets/asia/ofa/petition/011_steila_WA/011_pf.pdf Accessed May 20, 2018.

1885 United States Indian Census Rolls, 1885-1940. Digital Image Available at Ancestry.com 
1887 United States Census. King County. Washington State \& Territorial Census, 1857-1892. Digital Image available at Ancestry.com

Journals:

Baldwin, Alice Blackwood. An Army Wife on the Frontier: The Memoirs of Alice Blackwood Baldwin, 1867-1877. Utah, the Mormons, and the West: No. 6. Salt Lake City: Tanner Trust Fund, University of Utah Library, 1975.

Grierson, Alice Kirk, and Shirley A. Leckie. The Colonel's Lady on the Western Frontier: The Correspondence of Alice Kirk Grierson. Women in the West. Lincoln: University of Nebraska Press, 1989.

Kautz, August V., and Reese, Gary Fuller. Nothing Worthy of Note Transpired Today: The Northwest Journals of August V. Kautz. Takoma: Tacoma Public Library, 1978.

Newspapers:

Arizona Miner

Daily Courier

Daily Olympian

Oregonian

Tacoma Daily News

Truth Teller

\section{Secondary Sources}

Books:

Anderson, Kim. A Recognition of Being: Reconstructing Native Womanhood. Toronto: Sumach Press, 2000.

Armitage, Susan H. and Elizabeth Jameson, The Women's West. 1st ed. Norman: University of Oklahoma Press, 1987.

Asher, Brad. Beyond the Reservation: Indians, Settlers, and the Law in Washington Territory, 1853-1889. Norman: University of Oklahoma Press, 1999.

Billington, Ray Allen, and Ridge, Martin. Westward Expansion: A History of the American Frontier. 5th ed. New York: London: Macmillan; Collier Macmillan Publishers, 1982. 
Blackhawk, Ned. Violence Over the Land: Indians and Empires in the Early American West. Cambridge, Mass.: Harvard University Press, 2006.

Blee, Lisa. Framing Chief Leschi: Narratives and the Politics of Historical Justice. First Peoples (2010). Chapel Hill: University of North Carolina Press, 2014.

Brownlie, Robin, and Valerie J. Korinek. Finding a Way to the Heart: Feminist Writings on Aboriginal and Women's History in Canada. Winnipeg, Manitoba: University of Manitoba Press, 2012.

Burnard, Trevor G. Mastery, Tyranny, and Desire: Thomas Thistlewood and His Slaves in the Anglo-Jamaican World. Chapel Hill: University of North Carolina Press, 2004.

Carpenter, Cecelia Svinth, Maria Victoria Pascualy and Trisha Hunter. Nisqually Indian Tribe. Charleston, SC: Arcadia, 2008.

Carpenter, Cecelia Svinth. Fort Nisqually: A Documented History of Indian and British Interaction. Tacoma, Wash.: Tahoma Research Service, 1986.

Carpenter, Cecelia Svinth. The Nisqually--My People: The Traditional and Transitional History of the Nisqually Indian People. Tacoma, Wash.: Tahoma Research Service, 2002.

Chinoy, Helen, and Linda Walsh Jenkins. Women in American Theatre: Careers, Images, Movements: An Illustrated Anthology and Sourcebook. 1st ed. New York: Crown Publishers, 1981.

Collins, Thomas. Arizona on Stage: Playhouses, Plays, and Players in the Territory, 1879-1912. Guilford, Connecticut, 2016.

Cott, Nancy F. Public Vows: A History of Marriage and the Nation. Cambridge, Mass.: Harvard University Press, 2000.

Dudden, Faye E. Women in the American Theatre: Actresses and Audiences, 1790-1870. New Haven: Yale University Press, 1994.

Echo-Hawk, Walter R. In the Courts of the Conqueror: The 10 Worst Indian Law Cases Ever Decided. Golden, Colo.: Fulcrum Pub., 2010.

Eckrom, J. A. Remembered Drums: A History of the Puget Sound Indian War. Walla Walla, Wash.: Pioneer Press Books, 1989. 
Greene, Jerome A. American Carnage: Wounded Knee, 1890. Norman, Oklahoma: University of Oklahoma Press, 2014.

Haeberlin, Herman Karl, and Erna Gunther. The Indians of Puget Sound. University of Washington Publications in Anthropology; v. 4, No. 1. Seattle, Wash.: University of Washington Press, 1930.

Herman, Daniel J. Rim Country Exodus: A Story of Conquest, Renewal, and Race in the Making. Tucson, Arizona: University of Arizona Press, 2012.

Hillstrom, Kevin, and Laurie Collier Hillstrom. American Indian Removal and the Trail to Wounded Knee. Detroit, MI: Omnigraphics, 2010.

Hine, Robert V., and Faragher, John Mack. The American West: A New Interpretive History. New Haven, Conn.: Yale University Press, 2000.

Hixson, Walter L. American Settler Colonialism: A History. First ed. New York, NY: Palgrave Macmillan, 2013.

Hyde, Anne F. Empires, Nations, and Families: A History of the North American West, 1800-1860. Lincoln: University of Nebraska Press, 2011.

Jacobs, Margaret D. White Mother to a Dark Race: Settler Colonialism, Maternalism, and the Removal of Indigenous Children in the American West and Australia, 1880-1940. Lincoln: University of Nebraska Press, 2009.

Jacoby, Karl. Shadows at Dawn: An Apache Massacre and the Violence of History. New York: Penguin Books, 2009.

Jagodinsky, Katrina. Legal Codes and Talking Trees: Indigenous Women's Sovereignty in the Sonoran and Puget Sound Borderlands, 1854-1946. Lamar Series in Western History. New Haven: Yale University Press, 2016.

Jetté, Melinda Marie. At the Hearth of the Crossed Races: A French-Indian Community in Nineteenth-century Oregon, 1812-1859. First Peoples (2010). Corvallis: Oregon State University Press, 2015.

Kautz, Lawrence G. August Valentine Kautz, USA: Biography of a Civil War General. Jefferson, N.C.: McFarland \&, Publishers, 2008.

Limerick, Patricia Nelson. The Legacy of Conquest: The Unbroken Past of the American West. New York: W. W. Norton and Company, 2006. 
Loomba, Ania. Colonialism-postcolonialism. New Critical Idiom. London; New York: Routledge, 1998.

McConaghy, Lorraine., and Center for the Study of the Pacific Northwest. Warship under Sail: The USS Decatur in the Pacific West. Emil and Kathleen Sick Lecture-book Series in Western History and Biography; 15. Seattle: Center for the Study of the Pacific Northwest: in Association with University of Washington Press, 2009.

Meeker, Ezra. Pioneer Reminiscences of Puget Sound: The Tragedy of Leschi. Lowman \& Hanford Stationery and Printing, 1905.

Nacy, Michele. Members of the Regiment: Army Officers' Wives on the Western Frontier, 1865-1890. Westport, Conn: Praeger, 2000.

Ostler, Jeffrey. The Plains Sioux and U.S. Colonialism from Lewis and Clark to Wounded Knee. Cambridge Studies in North American Indian History. Cambridge; New York: Cambridge University Press, 2004.

Pascoe, Peggy. What Comes Naturally: Miscegenation Law and the Making of Race in America. Oxford, England; New York, NY: Oxford University Press, 2009.

Peterson Del Mar, David. The American Family: From Obligation to Freedom. Rev. edition. New York: Palgrave Macmillan, 2011.

Peterson Del Mar, David. Beaten Down: A History of Interpersonal Violence in the West. Seattle: University of Washington Press, 2002.

Peterson Del Mar, David. What Trouble I Have Seen: A History of Violence against Wives. Cambridge, Mass.: Harvard University Press, 1996.

Scharff, Virginia, Brucken, Carolyn. Home Lands: How Women Made the West. Los Angeles: Berkeley: Autry National Center of the American West; in Association with University of California Press, 2010.

Schlissel, Lillian, Ruíz, Vicki, et al. Western Women: Their Land, Their Lives. 1st ed. Albuquerque: University of New Mexico Press, 1988.

Slotkin, Richard. Regeneration through Violence: The Mythology of the American Frontier, 1600-1860. 1st ed. Middletown, Conn.: Wesleyan University Press, 1973. 
Smith, Sherry L. The View from Officers' Row: Army Perceptions of Western Indians. Tucson: University of Arizona Press, 1990.

Stephanson, Anders. Manifest Destiny: American Expansionism and the Empire of Right. 1st ed. A Critical Issue. New York: Hill and Wang, 1995.

Sturtevant, William C. Handbook of the North American Indians. Vol. 7 Washington: Smithsonian Institution, 1978.

Van Kirk, Sylvia. "Many Tender Ties": Women in Fur-Trade Society in Western Canada, 1670-1870. Winnipeg, Man: Watson \& Dwyer, 1980.

Wellman, Candace. Interwoven Lives: Indigenous Mothers of Salish Coast Communities. Pullman, Washington: Washington State University Press, 2019.

Wellman, Candace. Peace Weavers: Uniting the Salish Coast through Crosscultural Marriages. Pullman, Washington: Washington State University Press, 2017.

White, Richard. "It's Your Misfortune and None of My Own": A History of the American West. 1st ed. Norman: University of Oklahoma Press, 1991.

White, Richard. The Middle Ground: Indians, Empires, and Republics in the Great Lakes Region, 1650-1815. Cambridge Studies in North American Indian History. Cambridge; New York: Cambridge University Press, 1991.

Wilkinson, Charles F. Messages from Frank's Landing: A Story of Salmon, Treaties, and the Indian Way. Seattle: University of Washington Press, 2000.

Journal Articles:

Addis, Cameron. "The Whitman Massacre: Religion and Manifest Destiny on the Columbia Plateau, 1809-1858." Journal of the Early Republic 25, no. 2 (2005): 221-58.

Adelman, Jeremy and Stephen Aron. "From Borderlands to Borders: Empires, Nation-States, and the Peoples in Between in North American History." The American Historical Review 104, no. 3 (1999): 814-41.

Arnold, Laurie. "More than Mourning Dove: Christine Quintasket-Activist, Leader, Public Intellectual." Montana the Magazine of Western History 67, 1 (Spring 2017): 28-45. 
Basehart, Harry W. "Mescalero Apache Band Organization and Leadership." Southwestern Journal of Anthropology 26, no.1 (1970): 87-106.

Borch, Fred L. "“Let the Stain of Innocent Blood Be Removed from the Land": The Trial of the Lincoln Assassination Conspirators by Military Commission." Army History, no. 86 (2013): 6-19.

Brandes, Ray. "A Guide to the History of the U. S. Army Installations in Arizona, 1849-1886." Arizona and the West 1, no. 1 (1959): 42-65.

Demontravel, Peter R. "General Nelson A. Miles and the Wounded Knee Controversy." Arizona and the West 28, no. 1 (1986): 23-44.

Edmunds, R. David. "Blazing New Trails or Burning Bridges: Native American History Comes of Age." Western Historical Quarterly 39, no. 1 (2008): 415.

Elliott, Charles. "An Indian Reservation Under General Crook." Military Affairs 12 (1948): 91-102.

Galbraith, John S. "The British and Americans at Fort Nisqually, 1846-1859." The Pacific Northwest Quarterly 41, no. 2 (1950): 109-20.

Gilmer, Jason. "Crimes of Passion: The Regulation of Interracial Sex in Washington, 1855-1950." Gonzaga Law Review Vol. 47:2 (2011/12): 393428.

Glenn, Evelyn Nakano. "Settler Colonialism as Structure: A Framework for Comparative Studies of U.S. Race and Gender Formation." Sociology of Race and Ethnicity 1, no. 1 (2015): 52-72.

Hareven, Tamara K. "The History of the Family and the Complexity of Social Change." The American Historical Review 96, no. 1 (1991): 95-124.

Hussey, John A. "The Women of Fort Vancouver." Oregon Historical Quarterly 92, no. 3 (1991): 265-308.

Hyde, Anne F. "The Blue Flower and the Account Book: Writing a History of Mixed-Blood Americans." Pacific Historical Review 85, no. 1 (2016):1-22.

Jacobs, Margaret. "The Eastmans and the Luhans: Interracial Marriage between White Women and Native American Men, 1875-1945." Frontiers: $A$ Journal of Women Studies 23, no. 3 (2002): 29-54. 
Jacobs, Margaret. "Getting Out of a Rut: Decolonizing Western Women's History." Pacific Historical Review 79, no. 4 (2010): 585-604.

Jacobs, Margaret. "Western History: What's Gender Got to Do With It?" Western Historical Quarterly 42, no. 3 (2011): 297-304.

Jacoby, Karl. "Golden State, Genocide State." Journal of Genocide Research 19, no. 1 (2017): 133-36.

Jagodinsky, Katrina. "“In Family Way": Guarding Indigenous Women's Children in Washington Territory." American Indian Quarterly 37, no. 1-2 (2013): 16077.

Jameson, Elizabeth. "Looking Back to the Road Ahead." Pacific Historical Review 79, no. 4 (2010): 574-84.

Jameson, Elizabeth. "Women as Workers, Women as Civilizers: True Womanhood in the American West." Frontiers: A Journal of Women Studies 7, no.3 (1984):1-8.

Johnston, Robert. "'There's No 'There' There”: Reflections on Western Political Historiography." Western Historical Quarterly 42, no. 3 (2011): 331-37.

Leong, K J. "Still Walking, Still Brave: Mapping Gender, Race, and Power in U.S. Western History." Pacific Historical Review 79, no. 4 (2010): 618-28.

Limerick, Patty. "Examining "The Heart of the West"." The Public Historian 31, no. 4 (2009): 90-96.

Lujan, Carol and Gordon Adams. "U.S. Colonization of Indian Justice Systems: A Brief History." Wicazo Sa Review 19, no. 2 (2004): 9-23.

Mclnnis, Verity G. "Indirect Agents of Empire: Army Officers' Wives in British India and the American West, 1830-1875." Pacific Historical Review 83, no. 3 (2014): 378-409.

McManus, Sheila. "'Their Own Country": Race, Gender, Landscape, and Colonization around the 49th Parallel, 1862-1900." Agricultural History 73, no. 2 (1999): 168-82.

Milliken, Emma. "Choosing between Corsets and Freedom: Native, Mixed-Blood, and White Wives of Laborers at Fort Nisqually, 1833-1860." The Pacific Northwest Quarterly 96, no. 2 (2005): 95-101. 
Myres, Sandra L. "Romance and Reality on the American Frontier: Views of Army Wives." The Western Historical Quarterly 13, no. 4 (1982): 409-427.

Pascoe, Peggy. "Miscegenation Law, Court Cases, and Ideologies of "Race" in Twentieth-Century America." The Journal of American History 83, no. 1 (1996): 44-69.

Peterson Del Mar, David. "Intermarriage and Agency: A Chinookan Case Study." Ethnohistory 42, no. 1 (1995): 1-30.

Prosch, Thomas W. "The United States Army in Washington Territory." The Washington Historical Quarterly 2, no. 1 (1907): 28-32.

Roberts, Mary Louise. "True Womanhood Revisited." Journal of Women's History 14, no. 1 (2002): 150-155.

Schmitt, Martin. "The Execution of Chief Leschi and the "Truth Teller"." Oregon Historical Quarterly 50, no. 1 (1949): 30-39.

Sinclair, Donna.. Part I, 'Our Manifest Destiny Bids Fair for Fulfillment': An Historical Overview of Vancouver Barracks, 1846-1898, with Suggestions for Further Research. Center for Columbia River History, 2004.

Stewart, Miller. "Army Laundresses: Ladies of the 'Soap Suds Row.'” Nebraska History 61 (1980):421-36.

Turner, Frederick Jackson. "The Significance of the Frontier in American History." Presentation at the American Historical Society, Chicago: July 12, 1893.

Digital access: https://www.historians.org/about-aha-andmembership/aha-history-and-archives/historical-archives/the-significanceof-the-frontier-in-american-history Accessed June 2, 2019.

Van Kirk, Sylvia. "From 'Marrying-In' to 'Marrying-Out': Changing Patterns of Aboriginal/Non-Aboriginal Marriage in Colonial Canada." Frontiers: A Journal of Women Studies 23, no 3 (2002): 1-11.

Welter, Barbara. "The Cult of True Womanhood: 1820-1860." American Quarterly 18, no. 2 (1966): 151-74.

White, Richard. "Race Relations in the American West." American Quarterly 38, no. 3 (1986): 396-416. 
Wooster, Robert. "'A Difficult and Forlorn Country": The Military Looks at the American Southwest, 1850-1890." Arizona and the West 28, no. 4 (1986): 339-56.

Websites:

Browne, Sherri Bartlett. Oregon Encyclopedia. "Eva Emery Dye (1855-1947)." Oregon

Encyclopedia.https://oregonencyclopedia.org/articles/dye eva emery/\#.X O1lolhKiUk Accessed May 26, 2019.

Lang, William.Oregon Encyclopedia. "Creation of Washington Territory, 1853." https://oregonencyclopedia.org/articles/washington territory 1853/\#.XRp2 G-hKiUk Accessed June 28, 2019.

Serna, Mary M., and James W. Steely. "Mescalero Apache People." http://newmexicohistory.org/people/mescalero-apache-people. Accessed May 21, 2019. 